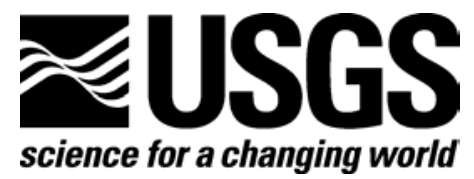

\title{
Locatable Mineral Reports for Colorado, South Dakota, and Wyoming provided to the U.S.D.A. Forest Service in Fiscal Years 2003-2005
}

By Anna B. Wilson

Open-File Report 2006-1018 


\section{CONTENTS}

INTRODUCTION ........................................... page

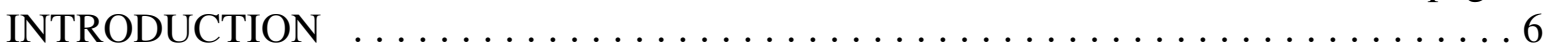

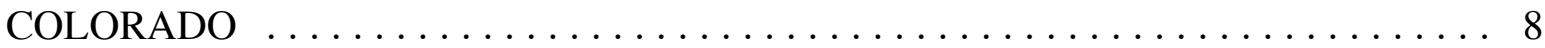

Arapaho/Roosevelt National Forests

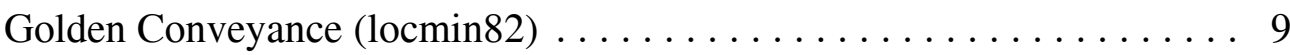

Routt/Gunnison National Forests

Big Creek Ranch (Needmore Ranch) Exchange (locmin79) . . . . . . . . 17

Pike/San Isabel National Forests

Round Hill (City and County of Denver) Exchange (locmin76) . . . . . 32

San Juan/Pike/San Isabel National Forests

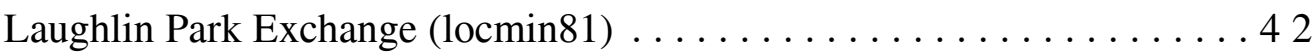

San Juan National Forest

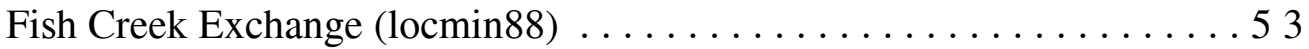

Uncompahgre National Forest

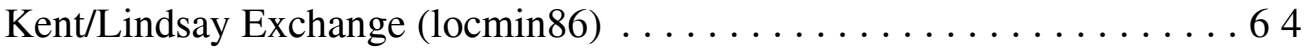

Telluride Airport Exchange (locmin89) . . . . . . . . . . . . . . 73

White River National Forest

South Game Creek (Vail Corporation) Exchange (locmin83) . . . . . 8 3

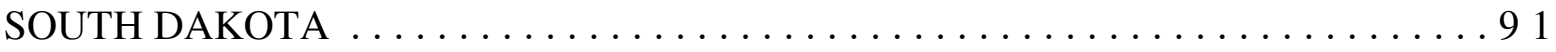

Black Hills National Forest

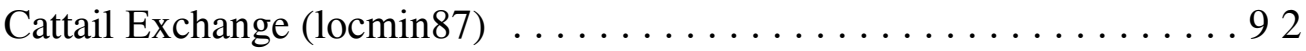

Nebraska National Forest

Buffalo Gap National Grasslands

Cole Draw (Edoff) Exchange (locmin 75) . . . . . . . . . . . . 105

Cortney Creek Ranch (Sides Ranch) Exchange (locmin 80) . . . . . . . 113

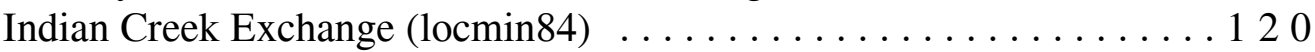

Fort Pierre National Grasslands

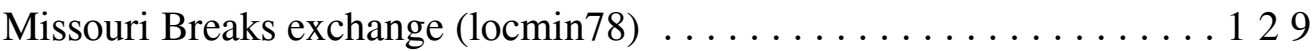

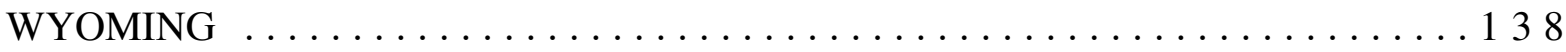

Bighorn/Black Hills National Forests

City of Buffalo (Tie Hack Reservoir) Exchange (locmin 77) . . . . . . 139

Medicine Bow National Forest

Thunder Basin National Grasslands

Cow Creek (Thomson) Exchange (locmin 85) . . . . . . . . . . . 149 


\section{FIGURES}

\section{COLORADO}

Arapaho/Roosevelt National Forests

Golden Conveyance (locmin82)

Fig. 1. Attachment A (Report Request) . . . . . . . . . . . 13

Fig. 2. Attachment B (Location description) . . . . . . . . 14

Fig. 3. Attachment $C$ (Geologic map, non-Federal) . . . . . . 15

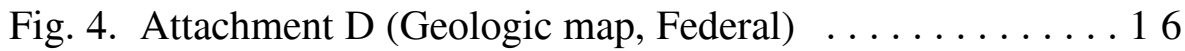

Routt/Gunnison National Forests

Big Creek Ranch (Needmore Ranch) (locmin79)

Fig. 5. Attachment A (Report Request) . . . . . . . . . . . 24

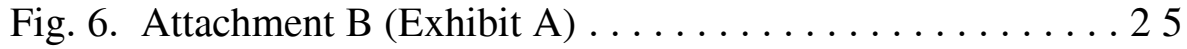

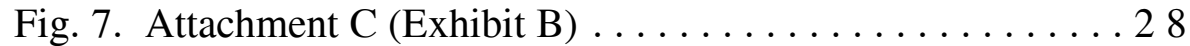

Fig. 8. Attachment D (Geologic map, Hahns Peak) . . . . . . . 29

Fig. 9. Attachment E (Geologic map, Kebler Pass) . . . . . . . 30

Fig. 10. Attachment $\mathrm{F}$ (Geology, Federal) . . . . . . . . . . 31

Pike/San Isabel National Forests

Round Hill (City and County of Denver) (locmin76)

Fig. 11. Attachment A (Exhibits A and B) ........... 38

Fig. 12. Attachment B (Report Request) . . . . . . . . . . . . 39

Fig. 13. Attachment C (Geologic map, Federal and non-Federal)

Fig. 14. Attachment D (Geologic map, non-Federal) . . . . . . 41

San Juan/Pike/San Isabel National Forests

Laughlin Park (locmin81)

Fig. 15. Attachment A (Exhibit A) ...............48

Fig. 16. Attachment B (Exhibit B) . . . . . . . . . . . 49

Fig. 17. Attachment $C$ (Report Request) ............ . 50

Fig. 18. Attachment D (Geologic map, Federal, non-Federal) . . 51

Fig. 19. Attachment E (Geologic map, non-Federal) . . . . . . 52

San Juan National Forest

Fish Creek (locmin88)

Fig. 20. Attachment A (Exhibit A) ............... . . 59

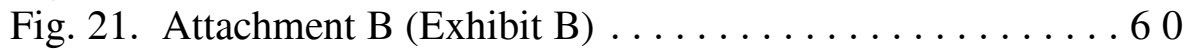

Fig. 22. Attachment $C$ (Report Request) .............6 1

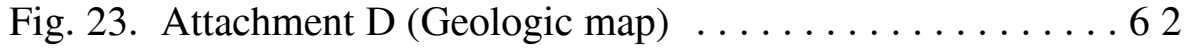

Fig. 24. Attachment E (Geologic map) . . . . . . . . . . 63 
Uncompahgre National Forest

Kent/Lindsay Exchange (locmin86)

Fig. 25. Attachment A (Report Request) . . . . . . . . . . . 69

Fig. 26. Attachment $B$ (Exhibits $A$ and B) .......... 70

Fig. 27. Attachment $\mathrm{C}$ (Geologic map, Non-Federal) . . . . . . . 71

Fig. 28. Attachment D (Geologic map, Federal) . . . . . . . . 72

Telluride Airport (locmin89)

Fig. 29. Attachment A (Exhibits A and B) ........... 78

Fig. 30. Attachment B (Report Request) . . . . . . . . . . . 79

Fig. 31. Attachment $\mathrm{C}$ (Geologic map) ............ 80

Fig. 32. Attachment D (Geologic map) ............ . 81

Fig. 33. Attachment E (Geologic map) ............ 82

White River National Forest

South Game Creek (Vail Corporation) (locmin83)

Fig. 34. Attachment A (Report Request) . . . . . . . . . . 88

Fig. 35. Attachment B (Location description, Exhibits A and B). . 89

Fig. 36. Attachment $\mathrm{C}$ (Geologic map) ............ 90

SOUTH DAKOTA

Black Hills National Forest

Cattail Exchange (locmin87)

Fig. 37. Attachment A (Exhibit A) . . . . . . . . . . . 99

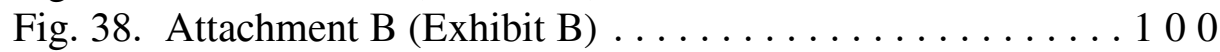

Fig. 39. Attachment $C$ (Report Request) . ............ 101

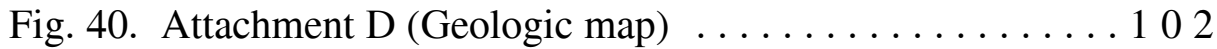

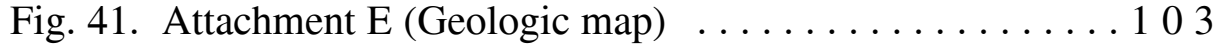

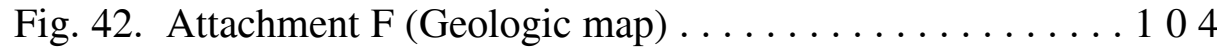

Nebraska National Forest

Buffalo Gap National Grasslands

Cole Draw (Edoff) Exchange (locmin75)

Fig. 43. Attachment A (Exhibit A) .............. 109

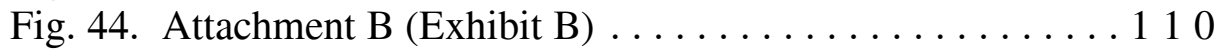

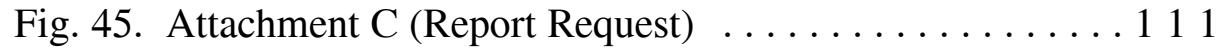

Fig. 46. Attachment D (Geologic map) . . . . . . . . . . . 112

Cortney Creek (Sides Ranch) Exchange (locmin80)

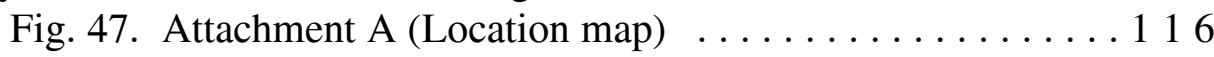

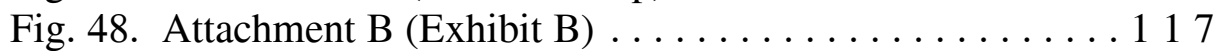

Fig. 49. Attachment C (Report Request) . . . . . . . . . . . . . 119

Indian Creek (Sides Ranch) Exchange (locmin84)

Fig. 50. Attachment A (Report Request) . . . . . . . . . . 125

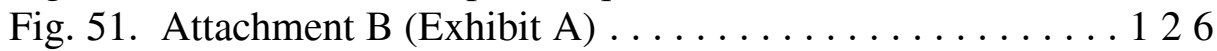

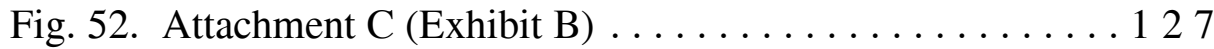


Fig. 53. Attachment D (Geologic map) _.............. 128 Fort Pierre National Grasslands

Missouri Breaks Exchange (locmin78)

Fig. 54. Attachment A (Report Request) . .............. 133

Fig. 55. Attachment B (Exhibit A) ................. 134

Fig. 56. Attachment C (Exhibit B) ................... 135

Fig. 57. Attachment D (Index map) ................. 136

Fig. 58. Attachment E (Geologic map) ............... 137

\section{WYOMING}

Bighorn/Black Hills National Forests

City of Buffalo (Tie Hack Reservoir) (locmin77)

Fig. 59. Attachment A (Exhibit A) . ................... 143

Fig. 60. Attachment B (Exhibit B) .................. 144

Fig. 61. Attachment C (Report Request) .............. 145

Fig. 62. Attachment D (Geologic map, non-Federal) ......... 146

Fig. 63. Attachment E (Geologic map, Federal) . . . . . . . . . 147

Fig. 64. Attachment F (Index map) .................. 148

Medicine Bow National Forest

Cow Creek (Thomson) Exchange (locmin85)

Fig. 65. Attachment A (Report Request) . .............. 152

Fig. 66. Attachment B (Exhibits A and B) ................. 153

Fig. 67. Attachment C (Geologic map) ............... 154 


\section{Locatable Mineral Reports for Colorado, South Dakota, and Wyoming provided to the U.S.D.A. Forest Service in Fiscal Years 2003-2005}

By Anna B. Wilson

\section{Introduction}

The U.S. Geological Survey is required by Congress (under Public Law 86-509) to provide Locatable Mineral Reports to the U.S.D.A. Forest Service whenever National Forest System lands are sold or exchanged. This volume is a compilation of the reports already provided to the Forest Service by the author in fiscal years 2003-2005 (October 2002 - September 2005). Altogether, the reports describe the geology and locatable mineral resource potential of 74 properties offered in 15 land exchange proposals. Approximately 16,207 acres were evaluated: 9,176 acres in 31 Federal parcels and 7,031 acres in 43 non-Federal parcels. The parcels are located in 13 National Forests and three National Grasslands in three States.

Locatable Mineral Reports provide a summary of the geology and a subjective appraisal of the mineral resource potential of land parcels considered for exchange. Information in each report is based on a review of published maps and reports, unpublished data in U.S. Geological Survey files, the professional expertise of the writer, and interviews with other knowledgeable geoscientists. Site visits are conducted only where it is deemed necessary (due to lack of available supporting or conflicting information), expedient, or cost-effective--only two days of field investigations support the reports included in this volume. The mineral resource information provided is used in making relative comparisons of the potential future mineral value of lands being offered in an exchange and in appraising the value of the land. Future mineral potential value is subjectively expressed in qualitative terms using a three-tier nomenclature of "high", "moderate", and "low". In general, "high" is applied where mineral deposits are present on the property or adjacent to it, or there are other indications that the area has been mineralized. "Moderate" is applied where mineralization is only suspected or where an area possesses some of the same geologic characteristics that are common to areas around known mineral deposits. A "low" value is routinely applied to all remaining areas, with the understanding that the information required to prove the absence of any mineral resource potential will never be available. Copies of the reports reside in U.S. Geological Survey Mineral Resource Program and U.S.D.A. Forest Service files.

Most recent land exchanges are proposed for mutual convenience to gather both Federal and private lands into manageable blocks. Land exchanges are being used to mitigate management and utilization problems associated with commingled Federal and private property ownership. Promotion of greater continuity of ownership and creation of more manageable and useable property units play an influential role in the property selection and consolidation process. Some proposals are by Towns, Counties, and States wishing to acquire lands to serve the common good 
of their constituencies. Others are motivated by ranchers wishing to consolidate or expand their grazing lands and increase the efficiency of their operations. Still others are proposed by owners of remote patented mining claims wishing to trade their tracts for more accessible parcels or to avoid liability for any potential hazards the site may develop as a result of prior mining. Many recent land-exchange offers are directed toward acquisition of public lands in high-value recreation areas (such as ski areas). Increasingly, there is more potential for litigation and controversy for land exchanges involving high-value real estate than for exchanges of lower profile grazing lands. Hence, locatable mineral reports must be reliable enough to withstand scrutiny from litigants vying for high-stakes real estate.

Fifteen reports are included in this volume. They are grouped by State, then alphabetically by Forest. Each starts with a cover letter and title page. Geologic descriptions of properties, their mineral potential, and references comprise the main body of each report. Legal descriptions (either verbatim or paraphrased from descriptions supplied by the Forest Service) of the property locations are included as attachments designated Exhibits A and B. Also included as attachments are the report request from the U.S.D.A. Forest Service and any index maps, geologic maps, or other figures or illustrations that are provided for the convenience of the Forest Service minerals examiner. The original page numbers for each individual report are retained, the larger number at the bottom of each page is the pagination for this volume. 
COLORADO 


\title{
LOCATABLE MINERAL REPORT FOR THE CITY OF GOLDEN CONVEYANCE, ARAPAHO AND ROOSEVELT NATIONAL FORESTS, CLEAR CREEK AND PARK COUNTIES, COLORADO
}

\author{
By \\ Anna B. Wilson \\ U.S. Geological Survey \\ Administrative Report
}

November 17, 2004

The following report is based on information contained in USGS mineral resource and commodity files, mineral information databases (MRDS and MAS), and on reports and maps available in the USGS library. These data are occasionally augmented with unpublished documents, personal communications, and professional experiences. No field studies or on-site visits were performed in preparing this report. Emphasis is primarily on locatable mineral resources. Leasable and salable resources are covered only if they appear in the above documents. Mineral resource assessments are subjective: the opinions expressed herein are entirely those of the author. 


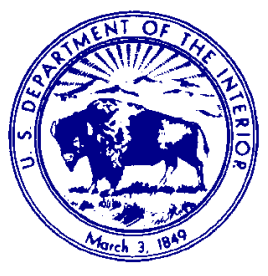

U.S. Department of the Interior

U.S. Geological Survey

Box 25046, MS 905

Denver Federal Center

Denver CO, 80225

(303) 236-5593

FAX (303) 236-3200

awilson@usgs.gov

November 17, 2004

Mr. Randall Karstaedt

Director, Physical Resources

U.S. Forest Service

PO Box 25127

Lakewood, CO 80225-0127

Dear Mr. Karstaedt:

This report is in response to your November 4 request for information on locatable mineral resources in a land exchange proposal in which the Secretary of Agriculture was directed to convey Federal lands within the Arapaho National Forest to the City of Golden in exchange for non-Federal lands, also within the Arapaho National Forest.

In accordance with our long-term working agreement under Public Law 86-509, we are providing you with a report on the locatable mineral resources on the lands described in Attachment B, which was included with your request. These lands comprise approximately 90 acres in Clear Creek and Park Counties, Colorado.

Sincerely yours,

Anna B. Wilson, Geologist

Mineral Resources Program, Central Region

Copies: $\quad$ C.J. Nutt

N. Hollenkamp

J.S. Dersch 
The report request is Attachment A. For the legal location description of lands considered for exchange, refer to Attachment B. Attachments C and D are simplified geologic maps showing the approximate locations of the Federal and non-Federal parcels.

\section{Non-Federal Lands}

\section{Cub Creek}

Meridian Hill 1:24,000, Denver West 1:100,000, Denver 1:250,000 quadrangles.

The Cub Creek parcel is located on the northern margin of the Lone Rock Pluton in late Middle Proterozoic Pikes Peak Granite (approx. 1,039 Ma). At the coarse scale of the available mapping $(1: 250,000)$ and based on Bruce Bryant's unpublished reconnaissance mapping, the northernmost part of the parcel may be in the Middle Proterozoic (approx. 1,400 Ma) quartz monzonite (monzogranite) of the Yankee Creek portion of the Mt. Evans Pluton (Bryant and Hedge, 1978; Bryant and others, 1981; Bryant, USGS, oral commun., Nov. 21, 2004).

There are no mines, prospects or mining districts in the vicinity (Wilson, 2003). The nearest ones are a clay prospect approximately $3.5 \mathrm{mi}$ east, a stone prospect approx. $5 \frac{1}{2} \mathrm{mi}$. to the south east, and a beryllium prospect about $5 \mathrm{mi}$. to the south. Of these, only the last is in the Pikes Peak Granite host rock. Bruce Bryant (oral commun., Nov. 21, 2004), in his mapping of the area, had no reason to suspect any mineralization in the vicinity. Mineral resource potential for locatable minerals is considered to be low.

\section{Federal Lands}

\section{Empire}

Empire 1:24,000, Denver West 1:100,000, Denver 1:250,000 quadrangles.

The arrowhead-shaped area included in this exchange is in West Fork of Clear Creek, west of the town of Empire. It is mapped primarily as undivided Quaternary alluvium, talus, solifluction debris, and morainal deposits overlying Tertiary monzonitic rocks (Braddock, 1969).

Mines and prospects in the immediate area include the Hidden Treasure and Allen Lode. Descriptions of these mines (Spurr and others, 1908) do not include production figures. The Hidden Treasure was developed by two tunnels, one of which had "been caved shut for some years" although it supposedly "produced a considerable ore of exceptionally rich nature" (Spurr and others, 1908, p. 409). It is said to have "produced the largest and finest specimens of native gold in the district. This free gold consisted of both leaf gold and of small irregular masses resembling nuggets." Cupriferous pyrite, sphalerite and galena were found on the dump (Spurr and others, 1908, p. 409). When they studied the ore deposits in the Front Range, Lovering and Goddard (1950, p. 160) briefly summarized Spurr and others' description of the Hidden Treasure but did not mention the Allen Lode. 
Locatable mineral resource potential of the hillside above the parcel would be high. However, no mineral resources have been discovered in the valley bottom in spite of relatively intense operations along the creek. Therefore, mineral resource potential of the parcel is predicted to be moderate.

\section{REFERENCES:}

Braddock, W.A., 1969, Geology of the Empire quadrangle, Grand, Gilpin, and Clear Creek Counties, Colorado: U.S. Geological Survey Professional Paper 616, 56 p., scale $1: 24,000$.

Bryant, Bruce, and Hedge, C.E., 1978, Granite of Rosalie Peak, a phase of the 1700-millionyear-old Mount Evans Pluton, Front Range, Colorado: U.S. Geological Survey Journal of Research, v. 6, no. 4, p. 447-451.

Bryant, Bruce, McGrew, L.W., and Wobus, R.A., 1981, Geologic map of the Denver $1^{\circ}$ X $2^{\circ}$ quadrangle, north-central Colorado: U.S. Geological Survey Miscellaneous Investigations Series Map I-1163, scale 1:250,000.

Lovering, T.S., and Goddard, E.N., 1950, Geology and ore deposits of the Front Range, Colorado: U.S. Geological Survey Professional Paper 223, 319 p.

Spurr, J.E., Garrey, G.H., and Ball, S.H., 1908, Economic geology of the Georgetown quadrangle (together with the Empire district), Colorado: U.S. Geological Survey Professional Paper 63, 422 p.

Wilson, A.B., 2003, Databases and simplified geology for mineralized areas, claims, mines and prospects in Colorado: U.S. Geological Survey Open-File Report 03-090.

\section{LIST OF ATTACHMENTS:}

A. Report Request (provided by U.S. Forest Service).

B. Legal description of Federal land considered in this exchange (provided by U.S. Forest Service).

C. Simplified geologic map showing location of Cub Creek parcel (modified from Bryant and others, 1981; Wilson, 2003).

D. Simplified geologic map showing location of the Federal parcel (modified from Braddock, 1969; Bryant and others, 1981; Wilson, 2003). 


\section{Attachment A. Report Request (provided by U.S. Forest Service)}

$\begin{array}{lll}\text { United States } & \text { Forest } & \text { Rocky } \\ \text { Department of } & \text { Service } & \text { Mountain } \\ \text { Agriculture } & & \text { Region }\end{array}$

P.O. Box 25127

Lakewood, CO 80225-0127

Delivery: $\mathbf{7 4 0}$ Simms Street

Golden, CO 80401

Voice: $303-275-5350$

TDD: 303-275-5367

File Code: $5430-2-1$

Date:

NOV 042004

Anna Wilson

Geologist

Central Mineral Resources

U.S. Geological Survey MS 905

Box 25046, Denver Federal Center

Denver, CO 80225

Dear Ms. Wilson:

The Arapaho and Roosevelt National Forests Land Exchange Act of 2004 (PL 108-346) directed the Secretary of Agriculture to convey Federal lands within the Arapaho National Forest to the City of Golden, Colorado, a Municipal Corporation of $91110^{\text {th }}$ Street, Golden, Colorado 80401, in exchange for certain non-Federal lands, also within the Arapaho National Forest. A copy of the legislation is enclosed. These lands are described in the legal descriptions which are enclosed. The lands to be exchanged are depicted on the maps also provided.

In accordance with the working agreement under Public Law 86-509, please provide a report on the locatable mineral resources on the lands described in the legislation. Please specify in your report the mineral or minerals involved. Please send your report to the letterhead address.

If you have questions, you may contact Nancy Hollenkamp at 303-275-5382.

Sincerely,

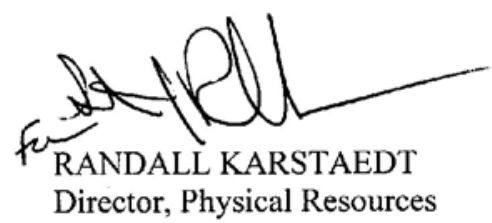

Enclosures

cc: Michael A Borkoski 
Attachment B. Location description (provided by U.S. Forest Service).

\section{Federal Parcel}

T.3S., R.74 W., $6^{\text {th }}$ P.M, Clear Creek County, Colorado.

Sec. 30, a parcel of land within the SW $1 / 4 \mathrm{NE}^{1 / 4}$ and $\mathrm{SE}^{1 / 4} \mathrm{NW}^{1 / 4}$

Approximately 10 acres to be determined by survey

\section{Non-Federal Parcel}

T.6S. R 72W. $6^{\text {th }}$ P.M., Park County Colorado

Sec $1 \mathrm{NW}^{1 / 4} \mathrm{SW}^{1 / 4}$

$\mathrm{Sec} 2 \mathrm{NE} 1 / 4 \mathrm{SE}^{1 / 4}$

80.00 acres 
Attachment C. Simplified geologic map showing location of Cub Creek parcel (modified from Bryant and others, 1981; Wilson, 2003). Yp, Middle Proterozoic Pikes Peak Granite (approx. 1,039 Ma) of the Lone Rock Pluton, Yg, Middle Proterozoic (approx. 1,400 Ma) quartz monzonite (monzogranite) of the Yankee Creek portion of the Mt. Evans Pluton.

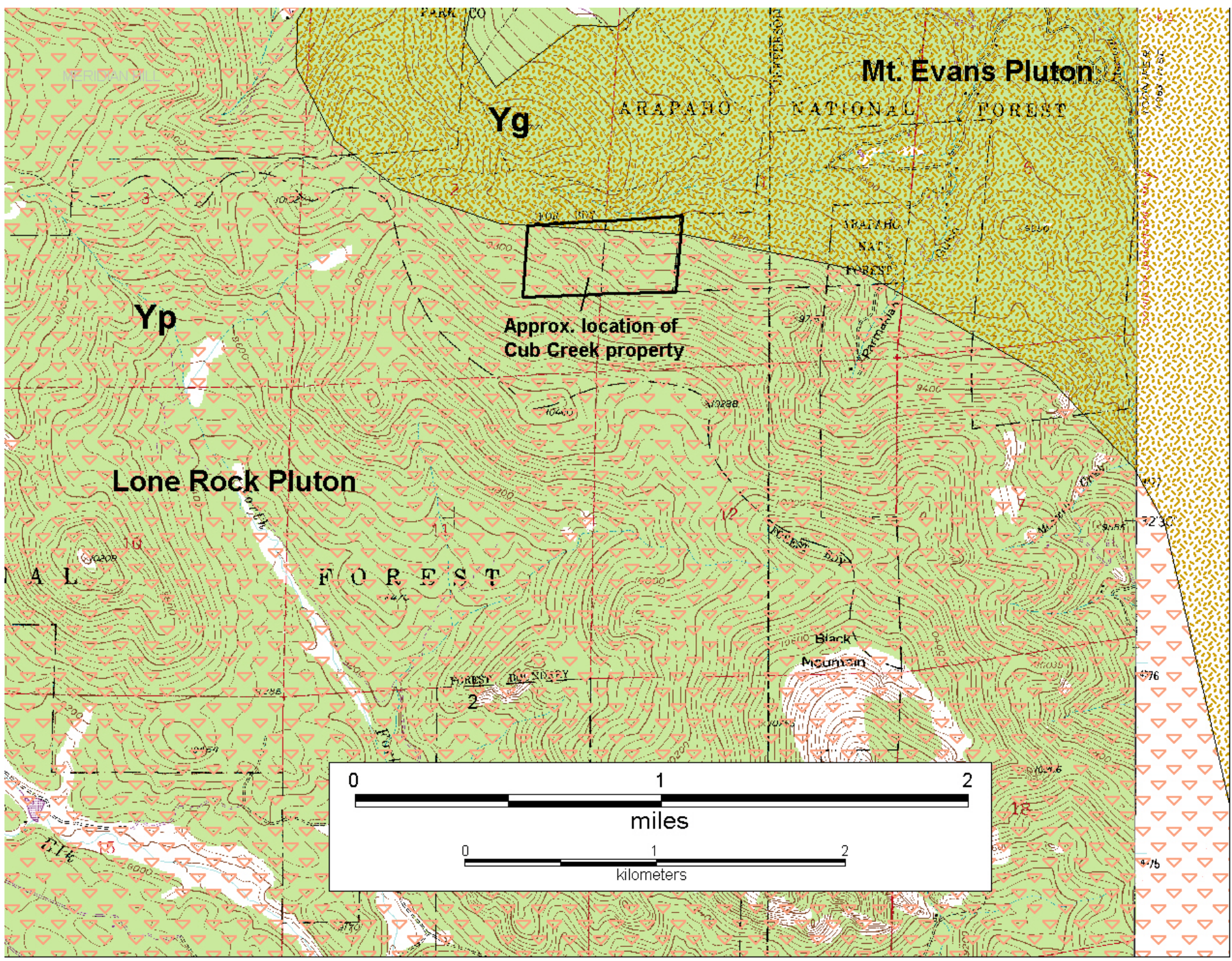


Attachment D. Simplified geologic map showing location of the Federal parcel (modified from Braddock, 1969; Bryant and others, 1981; and Wilson, 2003). Qa, Quaternary alluvium; Tm, Tertiary monzonite; Xm, Early Proterozoic gabbro and mafic diorite and monzonite; Xfh, Early Proterozoic felsic and hornblendic gneiss. Colored symbols indicate approximate location of mines and prospects, Hidden Treasure and Allen (Lincoln) mines shown as yellow squares.

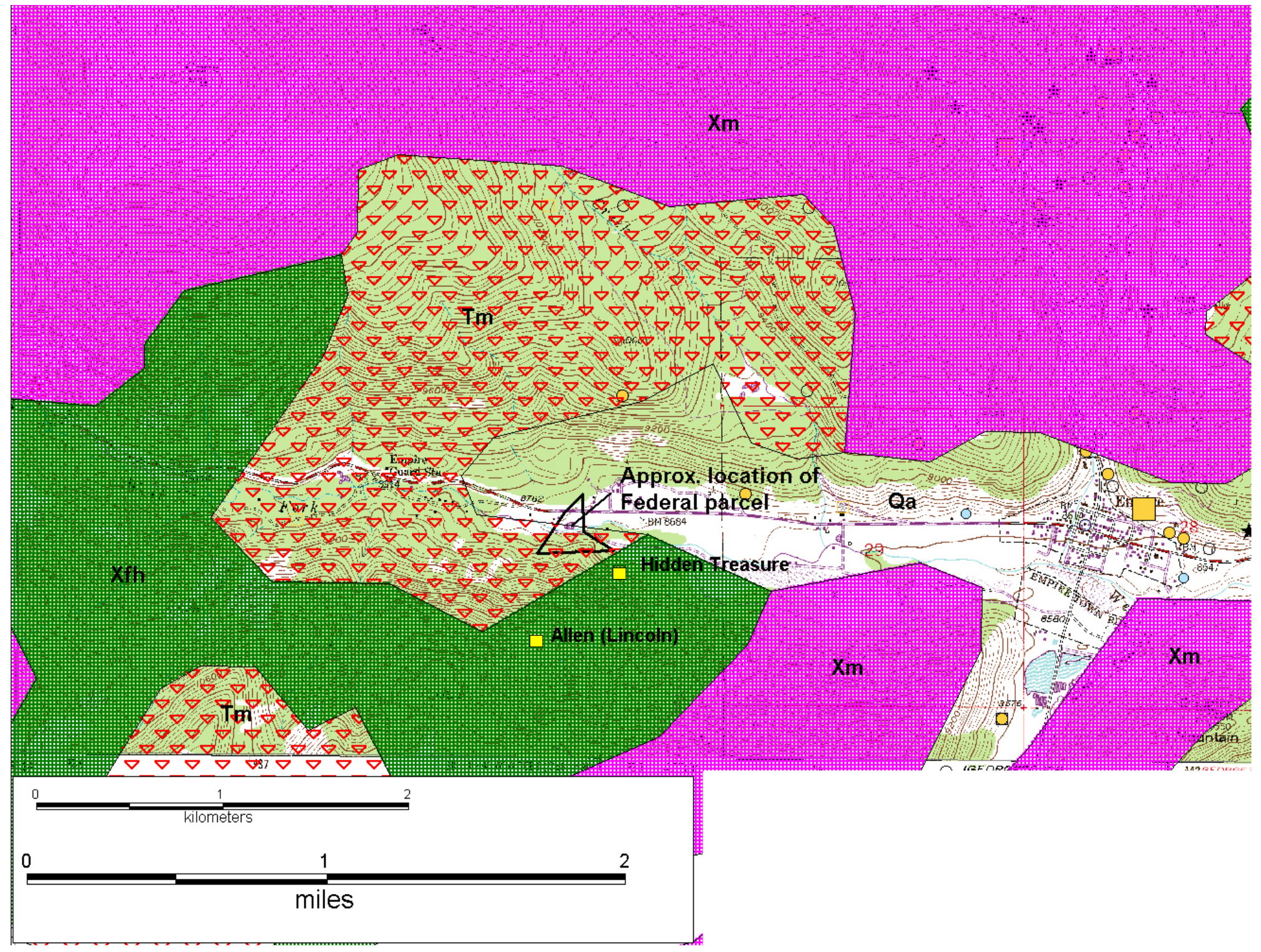




\title{
LOCATABLE MINERAL REPORT FOR THE BIG CREEK RANCH (Needmore Ranch II) LAND EXCHANGE OFFER, ROUTT AND GUNNISON NATIONAL FORESTS, ROUTT AND GUNNISON COUNTIES, COLORADO
}

\author{
By \\ Anna B. Wilson \\ U.S. Geological Survey \\ Administrative Report
}

Aug 15, 2004

The following report is based on information contained in USGS mineral resource and commodity files, mineral information databases (MRDS and MAS), and on reports and maps available in the USGS library. These data are occasionally augmented with unpublished documents, personal communications, and professional experiences. No field studies or on-site visits were performed in preparing this report. Emphasis is primarily on locatable mineral resources. Leasable and salable resources are covered only if they appear in the above documents. Mineral resource assessments are subjective: the opinions expressed herein are entirely those of the author. 


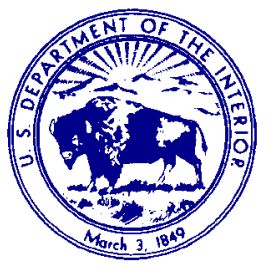

U.S. Department of the Interior

U.S. Geological Survey

Box 25046, MS 964

Denver Federal Center

Denver CO, 80225

(303) 236-5593

FAX (303) 236-3200

awilson@usgs.gov

August 20, 2004

Randall Karstaedt

Director, Physical Resources

U.S.D.A. Forest Service

PO Box 25127

Lakewood, CO 80225-0127

Dear Mr. Karstaedt:

This report is in response to your May 25 request for information on locatable mineral resources in the Big Creek Ranch land exchange proposal in which Needmore Ranch II has offered certain non-Federal lands within the Routt and Gunnison National Forests in exchange for Federal lands within Routt National Forest.

In accordance with our long-term working agreement under Public Law 86-509, we are providing you with a report on the locatable mineral resources on the lands described in Exhibits $\mathrm{A}$ and $\mathrm{B}$, which were included with your request. These lands comprise approximately 1597 acres in Routt and Gunnison Counties, Colorado.

Sincerely yours,

Anna B. Wilson, Geologist

Mineral Resources Program, Central Region

Copies: $\quad$ C.J. Nutt

N. Hollenkamp

J.S. Dersch 
Original Forest Service Request is in Attachment A. Locations of the lands considered for exchange are described in Attachments B and C.

\section{$\underline{\text { Non-Federal Lands }}$}

Parcel A. Hahns Peak

Hahns Peak 1:24,000, Walden 1:100,000, Craig 1:250,000 quadrangles.

This block of mining claims is located on the northwest flank of Hahns Peak in the Hahns Peak mining district. Relatively recent mineral resource assessments of this area were completed by the former U.S. Bureau of Mines (Neubert, 1994) and the U.S. Geological Survey (Bankey and others, 2000).

Geology of the area is described as "Mesozoic shale, quartzite, sandstone, and siltstone, all cut by porphyry dikes associated with the Hahns Peak intrusion" (Neubert, 1994, p. 12). "The Hahns Peak stock is highly altered, and silver-lead-zinc ore has been mined from the breccia surrounding it. The stock has been explored for porphyry molybdenum and disseminated gold deposits" (Neubert, 1994, p. 3). With one exception, most drill holes are on the south and southeast flanks of the peak (Casaceli, 1983).

Segerstrom and Young (1972) and Casaceli (1983) mapped the area at 1:24,000-scale. Attachment D shows the Segerstrom and Young (1972) geology. The oldest rocks exposed in the area are Jurassic Morrison and Sundance Formations (Attachment D, unit Jms, turquoise) in the central part of the parcel. Undifferentiated on the map, they consist of varicolored claystone and shale, yellowish to red-brown sandstone, and minor thin beds of limestone. Those exposures are nearly surrounded by Cretaceous Dakota Sandstone (Attachment D, unit Kd, olive green), a light-gray sandstone with minor dark-gray shale beds and a basal chert-pebble conglomerate. Cretaceous Mancos Shale (Attachment D, unit Km, mint green), dark-gray, calcareous, and locally fossiliferous, is the dominant rock-type exposed at the northwestern margin of the parcel. Most of the southeastern part of the parcel is in the 10-12 Ma composite intrusion of dikes, breccia, and altered quartz latite and latite porphyry (Attachment D, units Tp and Tpa, pink). Lithologies include late-stage quartz latite porphyry dikes, a pyroclastic base surge deposit, alternating beds of lapillistone and tuff comprising a vent complex, multilithic breccia, apatite dikes, monolithic intrusive breccia, and various latite porphyries. Quaternary landslide and colluvial deposits are exposed on the southwest and northern parts of the parcel.

The Royal Flush mine includes many or most of the claims comprising Parcel A, and is the most extensive mine in the area with more than 2,300 feet of workings on two levels (Neubert, 1994; Casaceli, 1983). In its early years, at 1909 prices, the mine produced "200 tons of ore averaging $\$ 90$ per ton in silver and lead" (Neubert, 1994). In the mid-1930s it produced 100 tons of ruby silver and galena ore from gouge seams containing 3,100 g gold, $248 \mathrm{~kg}$ silver, $20 \mathrm{~kg}$ copper, and $160 \mathrm{~kg}$ lead (Neubert, 1994, p. 12). 
The Tom Thumb mine, immediately south of Parcel A, was a silver mine that produced 200 tons of galena-rich ore (Casaceli, 1983, p. 7). An "assay of 18,000 lbs [9 tons] of ore contained 52 oz/ton silver, 2 oz/ton gold, and 51.8 percent lead" (Gale, 1906; Casaceli, 1983).

In recent years, the area has been explored for porphyry molybdenum by $\mathrm{W}$. Bowes of Steamboat, and by the former Anaconda Mining Company (Casaceli, 1983, Neubert, 1994).

Gold placers within $1 / 2$ to 2 mi. south of Parcel A at Ways Gulch and Deep Creek produced some gold between the 1860 s to 1941 and have produced only sporadically since that period. The value of production is estimated to be about $\$ 500,000$, mostly before 1909 (Neubert, 1994, p. 11-12).

With the exception of the Royal Flush mine, most of the production in the Hahns Peak mining district came from mines to the south of Parcel A.

A mineral resource assessment of this area was covered in the Routt National Forest mineral resource assessment at a scale of 1:250,000 (Soulliere and Toth, 2000). Parcel A is within an area (A1) assigned high potential (where available information gives a good indication of the level of mineral resource potential) for stockwork molybdenum type deposits including molybdenum, copper, lead, zinc, silver, and gold. Parcel A is also within an area (C2 )assigned high potential for polymetallic vein deposits containing lead, zinc, silver, and molybdenum. Areas of moderate and high gold placer potential are to the north and south of the parcel, respectively. Mineral resource potential of Parcel A for silver-lead-zinc, molybdenum, and placer gold is high; however, presence of an economic deposit has not been proven.

Parcel B. Kebler Pass Wetlands

Mount Axtell 1:24,000, Paonia 1:100,000, Montrose 1:250,000 quadrangles.

Gaskill and others (1987) mapped the area at 1:24,000 scale (Attachment E). The northern part of the Oligocene Mount Axtell laccolith ranges from granodiorite to quartz monzonite and quartz latite (Attachment E, unit Tp, pink). These lithologies are gradational with the granodiorite mapped in the southern part of the laccolith. The wetlands from Kebler Pass and along Coal Creek are in Quaternary deposits. Pleistocene glacial deposits (Attachment E, unit Qmy, yellow with tiny orange circles) are in the valley bottom with Holocene alluvial deposits (Attachment E, unit Qa, pale yellow) along the stream. There are several local debris and alluvial fan deposits (Attachment E, unit Qf, yellow with speckles) and talus deposits (Attachment E, unit Qt, medium yellow).

The parcel is located on the southernmost edge of the Ruby mining district (Wilson and others, 2000; Wilson and Spanski, 2004). However, most of the mining activity in the district was concentrated about $1 \frac{1}{2} \mathrm{mi}$ to the north at the Forest Queen and associated mines. Most mines in the district are in small polymetallic vein and replacement-type deposits. No mines, prospects, or occurrences are located in the parcel, although there are several claims in the general area. 
At a scale of 1:250,000, all of the area is permissive for the occurrence of polymetallic vein deposits, and most of the area may also be classified as "favorable" because it is within $3 \mathrm{~km}$ of a deposit or of a mineralized area containing polymetallic vein or polymetallic replacement deposits (Wilson and others, 2004a, b). Parcel B appears to be just outside the areas assigned any potential for polymetallic replacement deposits (Wilson and others, 2004b). Mineral resource potential of the Kebler Pass Wetlands parcel is moderate.

\section{Federal Lands}

Selected Federal Parcel 1

Clark, Floyd Peak, Rocky Peak, and Mad Creek 1:24,000, Walden 1:100,000, Craig 1:250,000 quadrangles.

Geologic mapping by Snyder (1980) indicates that the Federal Parcel is centered on a small basin exposing Miocene Browns Park Formation surrounded by Lower Cretaceous Dakota Sandstone and moving outward to upper Morrison Formation, a thin rim of Upper and Middle Jurassic Sundance Formation and Upper Triassic Chinle Formation, to Triassic and Permian(?) Chugwater, Red Peak Member, and Satanka(?) Formations. These Phanerozoic units are surrounded by Paleoproterozoic (X) felsic gneiss to amphibolite metavolcanics.

At 1:250,000 scale the parcel is in an area assigned moderate potential (area D2, Attachment F) for massive sulfides including lead, zinc, silver, copper, and gold (Soulliere and Toth, 2000). These deposits are found in Proterozoic calc-silicate and hornblende gneiss, amphibolite, and felsic gneiss units. However, most of the parcel is in the Phanerozoic rocks, and only the very periphery is in Proterozoic rocks. No productive mines or developed prospects for massive sulfides exist in the vicinity (Wilson, 2003). The nearest claim is located about $5 \mathrm{~km}$ north northeast of the parcel. Therefore, the mineral resource potential of this tract is considered to be low.

\section{REFERENCES:}

Bankey, Viki, Soulliere, S.J., and Toth, M.I., eds., 2000, Mineral resource potential and geology of the Routt National Forest and the Middle Park Ranger District of the Arapaho National Forest, Colorado: U.S. Geological Survey Professional Paper 1610, 117 p.

Casaceli, R.J., 1983, The geology and mineral potential of the Hahns Peak intrusive porphyry, Routt County, Colorado: Corvallis, Oregon State University Master's thesis, 223 p.

Gale, H.S., 1906, The Hahns Peak gold field, Colorado: U.S. Geological Survey Bulletin 285-A, p. 28-34.

Gaskill, D.L., DeLong, J.E., Jr., and Cochran, D.M., 1987, Geologic map of the Mt. Axtell quadrangle, Gunnison County, Colorado: U.S. Geological Survey Geologic quadrangle Map GQ-1604, scale 1:24,000. 
Neubert, J.J., 1994, Mineral appraisal of Routt National Forest, Colorado: U.S. Bureau of Mines Mineral Land Assessment Open-File Report MLA 13-94, 64 p. (plus appendices).

Segerstrom, K., and Young, E.J., 1972, General geology of the Hahns Peak and Farwell Mountain quadrangles, Routt County, Colorado: U.S. Geological Survey Bulletin 1349, $63 \mathrm{p}$.

Snyder, G.L., 1980, Geologic map of the central part of the northern Park Range, Jackson and Routt Counties, Colorado: U.S. Geological Survey Miscellaneous Investigations Series I-1112, scale 1:48,000.

Soulliere, S.J., and Toth, M.I., 2000, Mineral Resources-Locatable minerals, in Bankey, Viki, Soulliere, S.J., and Toth, M.I., eds., Mineral resource potential and geology of the Routt National Forest and the Middle Park Ranger District of the Arapaho National Forest, Colorado: U.S. Geological Survey Professional Paper 1610, 117 p.

Wilson, A.B., 2003, Databases and simplified geology for mineralized areas, claims, mines and prospects in Colorado: U.S. Geological Survey Open-File Report 03-090, CD-ROM. URL: http://pubs.usgs.gov/of/2003/ofr-03-090/

Wilson, A.B., and Spanski, G.T., 2004, Distribution of mines and mineralized areas, in Bankey, Viki, ed., Resource potential and geology of the Grand Mesa, Uncompahgre, and Gunnison (GMUG) National Forests and vicinity, Colorado: U.S. Geological Survey Bulletin 2213, Chapter E, p. 67-86. URL: http://pubs.usgs.gov/bul/2213/

Wilson, A.B., Nash, J.T., Spanski, G.T., Bankey, Viki, and Smith, S.M., 2004a, Mineral resource assessment for polymetallic vein deposits, in Bankey, Viki, ed., Resource potential and geology of the Grand Mesa, Uncompahgre, and Gunnison (GMUG) National Forests and vicinity, Colorado: U.S. Geological Survey Bulletin 2213, Chapter J, p. 150-163. URL: http://pubs.usgs.gov/bul/2213/

Wilson, A.B., Spanski, G.T., Bankey, Viki, and Smith, S.M., 2004b, Mineral resource assessment for polymetallic replacement deposits, in Bankey, Viki, ed., Resource potential and geology of the Grand Mesa, Uncompahgre, and Gunnison (GMUG) National Forests and vicinity, Colorado: U.S. Geological Survey Bulletin 2213, Chapter K, p. 164-176. URL: http://pubs.usgs.gov/bul/2213/

Wilson, A.B., Spanski, G.T., Crane, M.J., and Woodard, M.D., 2000, Databases and spatial data model for mineralized areas, mines, and prospects in the Grand Mesa, Uncompahgre, and Gunnison (GMUG) National Forests, Colorado: U.S. Geological Survey Open-File Report 00-298, CD-ROM. URL: http://pubs.usgs.gov/of/2000/ofr-00-0298/ 


\section{LIST OF ATTACHMENTS:}
A. Report request (provided by USDA Forest Service).
B. Exhibit A. Legal description of non-Federal land considered in this exchange (provided by USDA Forest Service).
C. Exhibit B. Legal description of Federal land considered in this exchange (provided by USDA Forest Service).
D. Geology of the Hahns Peak area (from Segerstrom and Young, 1972).
E. Geology of the Kebler Pass Wetlands area (from Gaskill and others, 1987).
F. Simplified geology and resource potential of the Federal Parcel (from Soulliere and Toth, 2000). 


\section{Attachment A. Report request (provided by U.S. Forest Service)}

$\begin{array}{lll}\text { United States } & \text { Forest } & \text { Rocky } \\ \text { Department of } & \text { Service } & \begin{array}{l}\text { Mountain } \\ \text { Region }\end{array} \\ \text { Agriculture } & & \end{array}$

Department of Agriculture
Region
Lakewood, CO 80225-0127

Delivery: 740 Simms Street

Golden, CO 80401

Voice: 303-275-5350

TDD: 303-275-5367
Date:

MAY 252004

Anna Wilson

Geologist

Central Mineral Resources

U.S. Geological Survey MS 905

Box 25046 - Denver Federal Center

Denver, CO 80225

Dear Ms. Wilson:

Needmore Ranch II, Ltd., a Texas limited partnership, acting by and through its agents, Western Land Group, Inc., of 507 South Sherman Street, Denver, Colorado, has offered certain nonFederal lands within the Routt and Gunnison National Forests, in exchange for Federal lands within the Routt National Forest. These lands are generally described in Exhibits A and B enclosed herewith. The lands to be exchanged are depicted on the maps also provided.

In accordance with the working agreement under Public Law 86-509, please provide a report on the locatable mineral resources on the lands described in Exhibits A and B. Please specify in your report the mineral or minerals involved. Please send your report to the letterhead address.

If you have any questions, you may contact Nancy Hollenkamp at (303) 275-5382.

Sincerely,

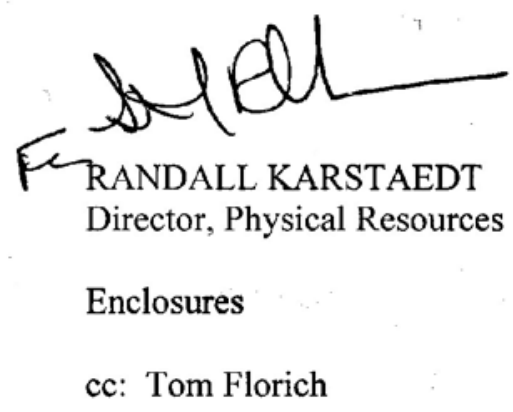




\section{Attachment B. Exhibit A (provided by U.S. Forest Service)}

\section{$\underline{\text { EXHIBIT A }}$}

Property that the Non-Federal Party will consider exchanging:

Non-Federal Parcel A, Hahn's Peak:

Township 10 North, Range 85 West, $6^{\text {th }}$ Principal Meridian

Those certain mining claims or premises described in Patent issued by the United States of America and recorded May 6, 1911, in Book 69 at Page 378 of the records of the County Clerk and Recorder of Routt County, Colorado, and known as the EL FORETA, ROYAL FLUSH, H.M. TELLER, PTARMIGAN, ONTARIO, SILENT FRIEND, WEDGE, TROJAN, and SPARTAN (U.S.M.S. NO 18297), located in the Hahn's Peak Mining District, and embracing a portion of Sections 8 and 9, Township 10 North, Range 85 West of the 6th Principal Meridian, County of Routt, State of Colorado.

EXCEPTING THEREFROM that portion of said ROYAL FLUSH mining claim conveyed to the United States of America by.Quit Claim Deed recorded October 27, 1941, in Book 207 at Page 366, said exception being described as follows:

Beginning at Corner No. 4 of said claim and extending thence North $62^{\circ} 05^{\prime}$ 'West 200 feet, thence North $30^{\circ} 10^{\prime}$ East 300.23 feet, thence South $62^{\circ} 05^{\prime}$ East 200 feet, to Corner No. 3 of said claim, thence South $30^{\circ} 10^{\prime}$ 'West 300.23 feet to Corner No. 4 of said claim, being the point of beginning. And excluding M.S. 11244, Tom Thum.

Those certain mining claims or premises described in patent issued by the United States of America and recorded July 5, 1912 in Book 73 at Page 498 of the records of the clerk and recorder of Routt County Colorado, and known as the CONUNDRUM NO. 1, CONUNDRUM NO. 2, CONUNDRUM NO. 4, CONUNDRUM NO. 5, CONUNDRUM NO. 6, CONUNDRUM NO. 7, CONUNDRUM NO. 8 and CONUNDRUM NO. 9, (U.S.M.S. NO. 18700) located in the Hahn's Peak Mining District and embracing a portion of Section 4, Section 5, Section 8, and Section 9, Township 10 North, Range 85 West of the 6th Principal Meridian, County of Routt, State of Colorado.

Those certain mining claims or premises described in patent issued by the United States of America and recorded December 28, 1908 in Book 40 at Page 226 of the records of the Clerk and Recorder of Routt County, Colorado, and known as Culver and Yellow Jacket Lode Mining Claims (U.S.M.S. NO. 16751) located in the Hahn's Peak Mining District and embracing a portion of Section 9, Township 10 North, Range 85 West of the 6th Principal Meridian, County of Routt, State of Colorado.

Containing 195.70 acre, more or less, Routt County, Colorado. 
Non-Federal Parcel B, Kebler Pass Wetlands:

Township 14 South, Range 87 West of the $6^{\text {th }}$ Principal Meridian

Section 10: SE1/4NE1/4 EXCEPTING therefrom any portion of the subject property which lies within the 200 foot right of way across the northeast quarter of Section 10, Township 14 South, Range 87 West, $6^{\text {th }}$ P.M., as set forth in Quit Claim Deed recorded September 5, 1956 in Book 321 at Page 69; County of Gunnison, State of Colorado; and

Section 11: S1/2NW1/4, W1/2SW1/4NE1/4, W1/2NW1/4SE1/4.

Containing 156.30 acres, more or less, Gunnison County, Colorado.

Containing an aggregate of 352.00 acres, more or less, Routt and Gunnison Counties, Colorado.

Land reservations of the Non-Federal Party and exceptions to title:

Reservations: None

Outstanding Rights:

Parcel A:

1. That the premises hereby granted, with the exception of the surface, may be enetered by the proprietor of a vien, lode or ledge, the top or apex of which lies outhside of the boundary of said grated premises, should the same in its dip be found to penetrate, intersect, or extend into said premises, for the purpose of extracting and removing the ore from such other vein, lode or ledge and right of way for ditches or canals constructed by the authority of the United States all as reserved in United States Patent recorded December 29, 1908, in Book 40 at Page 226.

2. That the premises hereby granted, with the exception of the surface, may be entered by the proprietor of a vein, lode or ledge, the top or apex of which lies outside of the boundary of said granted premises, should the same in its dip be found to penetrate, intersect, or extend into said premises, for the pupose of extracting and removing the ore from such other vein, lode or ledge and right of way for ditches or canals constructed by the authority of the United States all as reserved in United States Patent recorded May 6, 1911, in Book 69 at Page 378.

3. Right of way for ditches or canals constructed by the authority of the United States all as reserved in United States Patent recorded July 5, 1912, in Book 73 at Page 498.

4. Easement and right-of-way for trail purposes as granted to the United States of America in instrument recorded September 14, 1940 in Book 203 at Page 124, said easement being more particularly described therein.

5. Easement and right-of-way for telephone lines as granted to the United States of America in instrument recorded September 14, 1940 in Book 203 at Page 126, said easement being more particularly described therein. 
6. Any tax, lien or fee resulitng from inclusion in East Routt. Soil Conservation District as evidenced by Certificate recorded July 11, 1947 in Book 230 at Page 317 and the Steamboat Springs Cemetery District, as evidenced by Resolution recorded October 31, 1960 in Book 299 at Page 110.

7. Right of way for Hahns Peak Spring Pipeline as evidenced by map and statement recorded January 9, 1962 in File No. 6209.

8. Any tax, lien or fees resulting from the inclusion in Upper Yampa Water Conservancy District, by Order and Decree in the District Court, Routt County, Colorado, Civil Action No. 3815, recorded March 10, 1966 File No. 6612, under Reception No. 214808.

9. Resolution by the County of Routt recorded July 10, 1970 in File No. 6931, under Reception No. 224963, adopting the rules and regulations for the construction and maintenance of nonmunicipal waste disposal systems.

10. Reservation of a net proceeds royalty derived from the production of minerals by Harry $\mathrm{J}$. Sykes (3 1/3\%); James R. Keighley (3 1/3\%); William A. Bowes (5\%); and Bethea A. Martin (3 $1 / 3 \%)$. Also reservation of net proceeds derived from the sale of the property by Harry J. Sykes (1 $1 \frac{2}{2} \%$ ); James R. Keighley (2 $\left.1 / 2 \%\right)$; William a Bowes (2 $\left.1 / 2 \%\right)$; and Bethea A. Martin (2 1/2\%), all in the deed recorded April 25, 1994 in Book 696 at Page 1535. This exception shall be released of record at or prior to closing of this transaction.

11. Loss or damage by reason of any conflict of the Tom Thum Mining Claim MS \#11224 with the Royal Flush Mining Claim, and any conflict of the Golden Edge No. 1 Mining Claim with the Silent Friend Mining Claim, and the rights of parties in and to the Tom Thum and Golden Edge No. 1 Mining Claims, if any, which may be in conflict or have priority over the rights of the owners of said Royal Flush and Silent Friend Mining Claims.

\section{Parcel B:}

1. Reservations or exceptions, or an act authorizing the issuance thereof, as created by United States Patents recorded July 24, 1902 in Book 101 at Page 259, and recorded August 5, 1911 in Book 101 at Page 479.

2. Lease of Right of Way between Crested Butte and Kebler Pass as recorded June 3, 1932 in Book 241 at Page 410.

3. Sewer Installation and Inspection Agreement recorded November 15, 1978 in Book 523 at Page 988.

4. Easement recorded September 19, 1979 in Book 539 at Page 548.

5. Easement recorded June 15, 1982 in Book 580 at Page 702.

6. Easement and right of way for Kebler Pass Road.

7. Any rights, claims, or interest of the general public to roads or trails over and across the subject property.

8. Agreement With Developer For Indeterminate Service Plan Line Extension entered into between Coal Creek Corporation and the Gunnison County Electric Association, Inc., dated July 17, 1984 as set forth in Assignment of Contract Rights recorded December 19, 1991 in Book 699 at Page 395, and any and all assignments therof or interests therein.

9. Option Purchase Agreement between Crested Butte Land Trust, a Colorado non-profit organization, and Needmore Ranch II, Ltd., a Texas limited partnership, dated February 20, 2003, and First Amendment to Option Purchase Agreement dated August 5, 2003. Shall be satisfied at or prior to closing of this transaction. 


\title{
Attachment C. Exhibit B (provided by U.S. Forest Service).
}

\author{
EXHIBIT B
}

Property that the U.S.D.A. Forest Service will consider exchanging:

Township 8 North, Range 85 West, $6^{\text {th }}$ Principal Meridian

Section 13: SE1/4, SE1/4NE1/4, SE1/4SW1/4;

Section 23: E1/2SE1/4, SE1/4NE1/4;

Section 24: E1/2, E1/2W1/2, SW1/4NW1/4, W1/2SW1/4;

Section 25: N1/2NE1/4, N1/2SE1/4NE1/4, N1/2NW1/4,

S1/2NE1/4NE1/4SE1/4, S1/2NE1/4SE1/4, SE1/4SE1/4;

Section 26: NE1/4NE1/4.

Containing 1,245*(see “Other” below) acres, more or less, Routt County, Colorado.

Land reservations of the U.S.D.A Forest Servicem exceptions to title and uses to be recognized:

Reservations:

1. Reserving to the United States a right-of-way thereon for ditches or canals constructed by the authority of the United States Act of August 30, 1890 (26 Stat. 391; 43 U.S.C. 845).

Outstanding Rights: None

*Other:

Should it become necessary to drop Federal lands from the exchange proposal in order to equalize appraised values, the non-Federal party proposes dropping in the order shown below:

Township 8 North, Range 85 West, $6^{\text {th }}$ Principal Meridian, Routt County, $\mathrm{CO}$.

No. 1: Section 25: SE1/4SE1/4, S1/2NE1/4SE1/4, NE1/4NE1/4SE1/4, S1/2NW1/4NE1/4SE1/4, $\mathrm{S} 1 / 2 \mathrm{~N} 1 / 2 \mathrm{NW} 1 / 4 \mathrm{NE} 1 / 4 \mathrm{SE} 1 / 4$ (77.5 acres);

No. 2: Section 13: E1/2SE1/4, SE1/4NE1/4 (120 acres);

No 3: Section 24: E1/2NE1/4 (80 acres);

No 4: Section 24: E1/2SE1/4,

Section 25: NE1/4NE1/4, N1/2SE1/4NE1/4 (140 acres); 


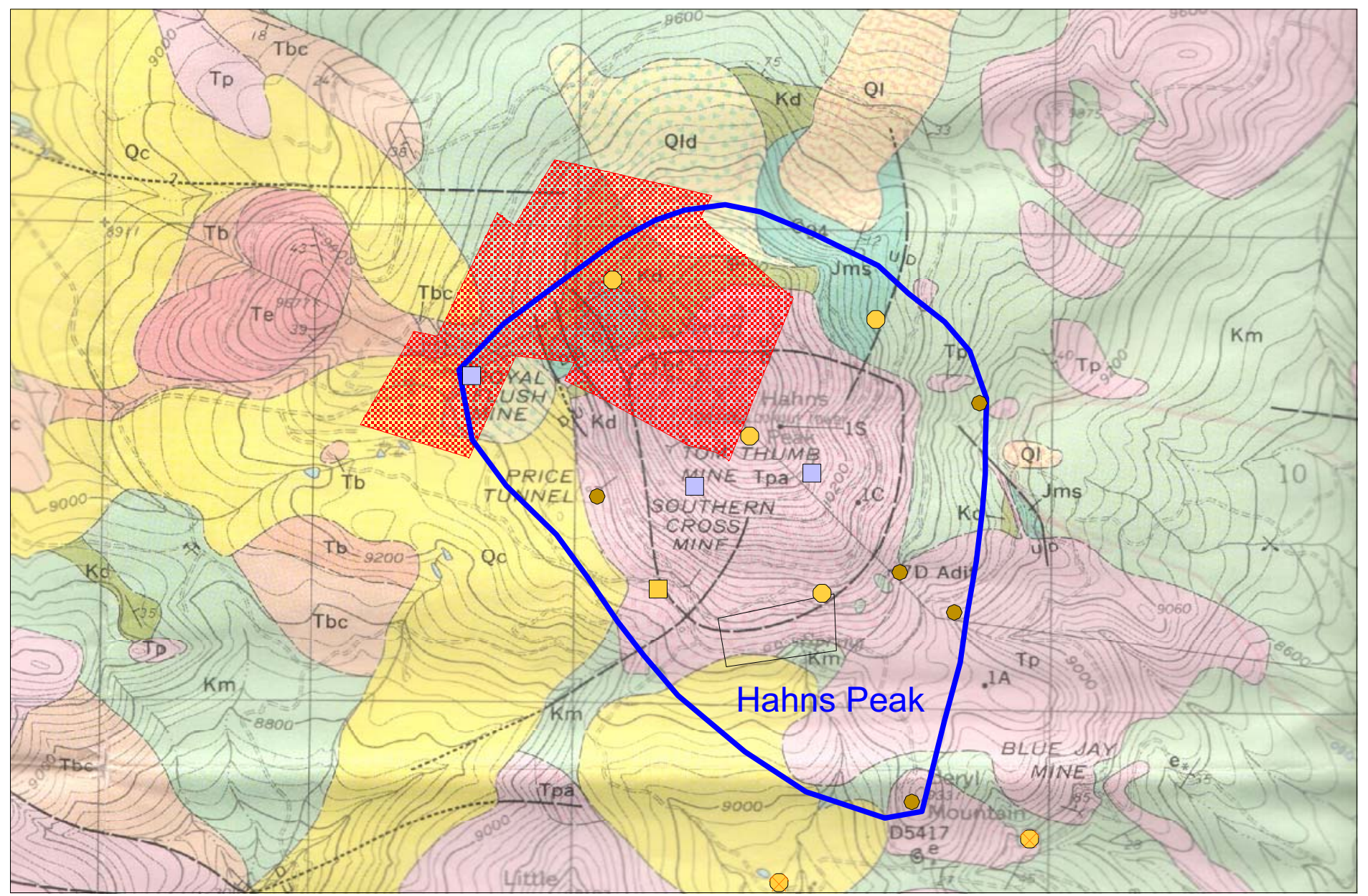

Attachment D. Geology of the Hahns Peak area (from Segerstrom and Young, 1972).

Area of interest shown in red. Hahns Peak mineralized area outlined in blue.

Mines and prospects from MAS (circles) and MRDS (squares) after Wilson (2003).

Pink stipples (Tpa), altered porphyry; pink (Tp), rhyolite, quartz latite, and rhyodacite intrusive porphyry; yellow (Qc), Quaternary colluvium; yellow with green stipples (Qld), Quaternary landslide deposits mostly of Dakota Sandstone; yellow with orange stipples (Ql), landslide deposits; mint green (Km), Cretaceous Mancos Shale; olive green (Kd), Cretaceous Dakota Sandstone; turquoise (Jms), Morrison and Sundance Formations. For other units, see Segerstrom and Young (1972). More geologic detail can be found on Casaceli's 1983 map. 


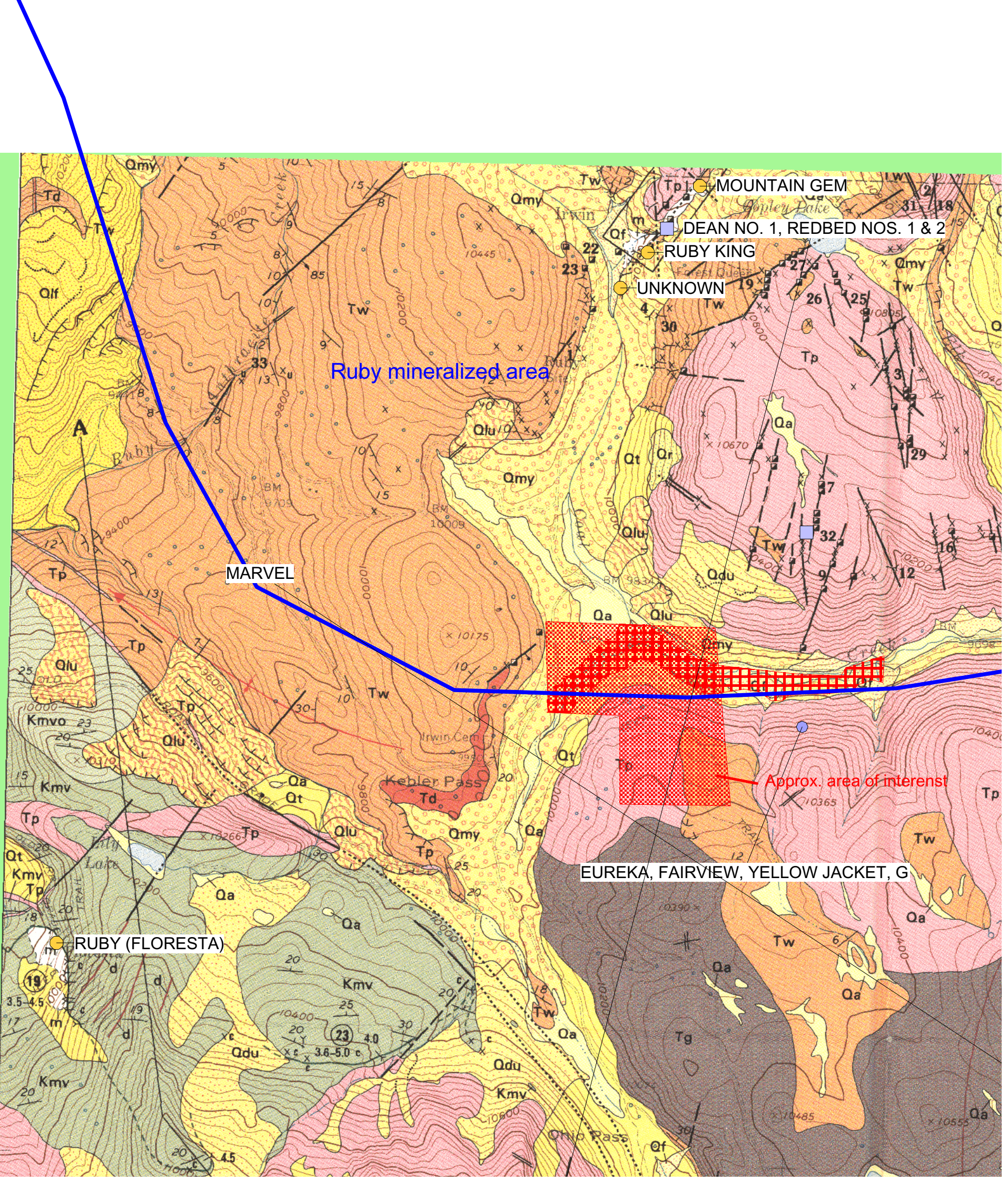

Attachment E. Geology of the Kebler Pass Wetlands area (from Gaskill and others, 1987).

Non-Federal Parcel and wetlands area shown in red patterns. Blue outlines Ruby mineralized area.

Mines and prospects from MAS (circles) and MRDS (squares) after Wilson (2003). 


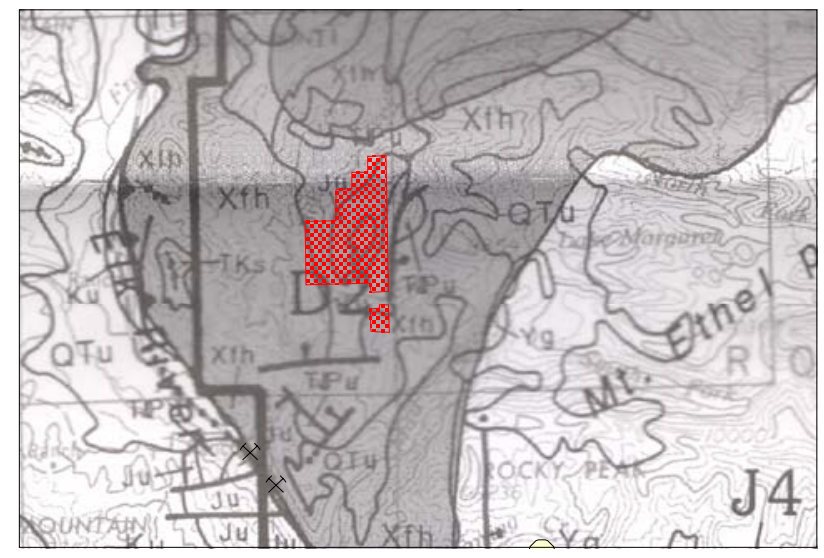

Attachment F. Simplified geology and resource potential of the Selected Federal Parcel (after Soulliere and Toth, 2000). Area of interest shown in red. Early Proterozoic (Xfh), Triassic to Pennsylvanian sedimentary rocks (TrPu), Jurassic sedimentary rocks (Ju), Cretaceous sedimentary rocks (Ku). 


\author{
LOCATABLE MINERAL REPORT FOR THE \\ ROUND HILL (City and County of Denver) EXCHANGE OFFER, \\ PIKE AND SAN ISABEL NATIONAL FORESTS, \\ DOUGLAS, HUERFANO, AND PARK COUNTIES, COLORADO
}

By

Anna B. Wilson

U.S. Geological Survey

Administrative Report

March 24, 2003

The following report is based on information contained in USGS mineral resource and commodity files, mineral information databases (MRDS and MAS), and on reports and maps available in the USGS library. These data are occasionally augmented with unpublished documents, personal communications, and professional experiences. No field studies or on-site visits were performed in preparing this report. Emphasis is primarily on locatable mineral resources. Leasable and salable resources are covered only if they appear in the above documents. Mineral resource assessments are subjective: the opinions expressed herein are entirely those of the author. 


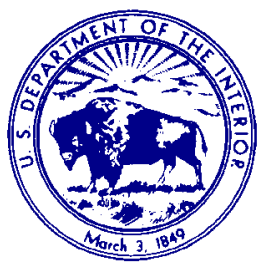

U.S. Department of the Interior

U.S. Geological Survey

Box 25046, MS 964

Denver Federal Center

Denver CO, 80225

(303) 236-5593

FAX (303) 236-3200

awilson@usgs.gov

March 24, 2003

Mr. M. M. Underwood

Director, Physical Resources

U.S. Forest Service

PO Box 25127

Lakewood, CO 80225-0127

Dear Mr. Underwood:

This report is in response to your February 20 request for information on locatable mineral resources in a land exchange proposal in which the City and County of Denver, acting by and through its Board of Water Commissioners, has offered certain non-Federal lands within the Pike and San Isabel National Forests in exchange for Federal lands also within the Pike and San Isabel National Forests.

In accordance with our long-term working agreement under Public Law 86-509, we are providing you with a report on the locatable mineral resources on the lands described in Exhibits $\mathrm{A}$ and $\mathrm{B}$, which were included with your request. These lands comprise approximately 1,150 acres in Douglas, Huerfano, and Park Counties, Colorado.

Sincerely yours,

Anna B. Wilson, Geologist

Mineral Resources Program, Central Region

Copies: $\quad$ W.C. Day

E.A. du Bray

N. Hollenkamp

J.S. Dersch 
For the legal location description of lands considered for exchange, refer to Exhibits A and B in Attachment A. The report request is Attachment B. Attachments C and D are simplified geologic maps showing the location of the Federal and Non-Federal parcels.

\section{$\underline{\text { Non-Federal Lands }}$}

Parcel A-1 "Round Hill Parcel"

Fairplay West 1:24,000, Leadville 1:100,000, Leadville 1:250,000 quadrangles.

The Round Hill parcel is east of Twelvemile Creek on the west flank and up to the summit of Round Hill. Mapped (Tweto, 1974; Tweto and others, 1978) as Pennsylvanian "Minturn and Belden Formations and related rocks", described as "gray and red sandstone, grit, and conglomerate, black shale, and locally abundant gypsum. Thickness as much as 9,000 (?) feet." May be overlain, especially at the lower elevations, by "older glacial drift" (Pleistocene-pre-Bull Lake) and by glacial drift (Pleistocene-Pinedale and Bull Lake)."

No mines, prospects, occurrences, or mining districts are in the vicinity. Mineral resource potential for locatable commodities is low.

Parcel A-2 "Harrington Ranch Parcel"

Garo 1:24,000, Bailey 1:100,000, Denver 1:250,000 quadrangles.

Harrington Ranch parcel, in the extreme southwest corner of the Garo 1:24,000, Bailey 1:100,000, and Denver 1:250,000 quadrangles, is mapped as the evaporate-bearing facies of the middle Pennsylvanian Minturn Formation. It is described as "gray shale, limestone, siltstone, sandstone, white silty limestone, anhydrite, and gypsum in southwest corner of mapped area. Flowage makes original thickness uncertain." [More detailed mapping may be available in a thesis by Efraim Lozano, 1965, Geology of the southwestern Garo area, South Park, Park County, Colorado: Colorado School of Mines MS thesis, 115 p. This thesis could not be obtained in timely fashion for this report.]

No mines, prospects, occurrences, or mining districts are in the vicinity. Mineral resource potential for locatable commodities is low.

Parcel A-3 "Westcreek Parcel"

Westcreek 1:24,000, Bailey 1:100,000, Denver 1:250,000 quadrangles.

Both parts of the parcel are mapped in the main body of the Pikes Peak batholith.

The only geologic mapping is the Denver $1^{\circ} \mathrm{X} 2^{\circ}$ quadrangle at 1:250,000-scale (Bryant and others, 1981). This map shows that the Northwestern Lode, in section 23, is in fine-grained granite (unit Ypf) which is described as "pink fine-grained equigranular biotite granite." The part of the parcel in section 26 is in the "pink to reddish medium- to coarse-grained, biotite or hornblende-biotite granite" (unit Ypp), the predominant rock type of the batholith. The small pluton at Thunder Butte (unit Ys), also part of the main body of the Pikes Peak batholith, is 
syenite described as "light-tan to gray-green, fine- to coarse-grained syenite, quartz syenite and leucosyenite, locally containing ferrohastingsite, fayalite, and hedenbergite."

Although the Northwestern Lode is a patented lode claim, there is no indication as to what type of deposit or commodity is there. By definition, at the time of patent, the claimant had to prove the existence of a valuable resource. Approximately 1/2 mile to the northwest, on the west flank of Thunder Butte, there is an unnamed occurrence of molybdenum (MAS 80357021, MRDS D010565). No other information about the site is available. Because the claim was patented, there is some chance that there is moderate potential for a locatable mineral deposit, but because it appears that it was never developed, the resource potential is probably not high. No other mines, prospects, occurrences, or mining districts are in the vicinity.

Parcel A-4 "Huerfano Claims"

Blanca Peak 1:24,000, Blanca Peak 1:100,000, Trinidad 1:250,000 quadrangles.

This group is described in 3 separate blocks: 1) Coronado Millsite, 2) Hawkins and Eagle Plume Lodes, and 3) Highline, Coronado, Copper King, Victor, Slide, Pilot, Skyscraper, and Ariel Lodes. All of the geologic descriptions that follow for these claims are based on the geologic mapping by Johnson and Bruce (1991).

Coronado Millsite is in Huerfano Creek and is mapped as Quaternary alluvium overlying Early Proterozoic tonalite gneiss. Hawkins and Eagle Plume Lodes are oriented north-northwesterly on the northeast flank of Blanca Peak parallel to, and possibly along, some of the many high angle faults in the area. The Hawkins Lode appears to follow a Proterozoic basaltic or gabbroic dike in Early Proterozoic white to light-gray-green, buff-weathering, homogeneous tonalite gneiss. Eagle Plume lode may straddle the faults that separate the tonalite gneiss on the east from dark-gray to very dark green Early Proterozoic metagabbro. The Highline-Coronado block is also in the Early Proterozoic metagabbro, but here it is cut by northeast-striking Miocene or Oligocene felsic (granitic) dikes.

The claim shapes near the center of the Blanca mining district indicate that these claims were patented. A millsite in Huerfano Creek indicates that the area did produce some ore. A mine labeled "McMillan Group" in both MRDS and MAS/MILS plots at the Eagle Plume Lode (Wilson, 2003). Supposedly, the McMillan (MRDS D006754, MAS 80557014) was developed for gold, silver, bismuth, copper, and tellurium. It is classified as an inactive prospect with a crosscut tunnel and a 40 ton concentrating mill. The millsite in Huerfano Creek may be this one. The McMillan deposit is described as tabular with the ore materials sylvanite(?), tellurobismuthite, and hessite (MRDS D006754). The Coronado-Highline Group (MRDS D010569, MAS 80557017), closer to the summit of Blanca Peak, was exploited for copper, gold, silver, and tellurium from chalcopyrite and unknown gold and silver minerals. These veins were developed by a 120-ft tunnel with $60-\mathrm{ft}$ raise, and $184 \mathrm{ft}, 75 \mathrm{ft}$, and $50 \mathrm{ft}$ crosscuts. Eagle Plume Lode is listed in the MRDS description as an unpatented claim. Mineral resource potential for this area is high; however it is not expected that the area contains an economically significant deposit. 


\section{Federal Lands}

\section{"Elevenmile Parcel"}

Elenvenmile Canyon 1:24,000, Pikes Peak 1:100,000, Pueblo 1:250,000 quadrangles.

The Elevenmile parcel is at the eastern edge of Elevenmile Canyon Reservoir. The area is mapped (Wobus and Epis, 1978) as Mesoproterozoic quartz monzonite (Yem) of Elevenmile Canyon and is dated at 1,460 Ma by Rb-Sr. This unit is described as "mottled pink and darkgray, medium-grained, porphyritic biotite quartz monzonite; massive to weakly foliated with pink subhedral microcline crystals [...] set in a biotite-rich groundmass." Smaller areas of the parcel are underlain by Mesoproterozoic quartz monzonite (unit Yqm, approximately $1.45 \mathrm{Ga}$ ) that is light-tan to pink, fine- to medium-grained muscovite-biotite quartz monzonite. The quartz monzonite (Yqm) is correlated with the Silver Plume Quartz Monzonite of the central Front Range. Also mapped in the area is Paleoproterozoic granodiorite (Xgd). Estimated to be $1.7 \mathrm{Ga}$, this unit is "pink to gray, medium- to coarse-grained biotite [or] biotite-hornblende granodiorite that is correlated with the Boulder Creek Granodiorite of the Central Front Range" (Wobus and Epis, 1978).

The nearest mineral deposit is an unnamed and little developed producer of barite, located approx. 3/4 mile to the northwest at Caylor Gulch (MRDS D004860, MAS 80930072). No other mines, prospects, occurrences, or mineral districts are in the vicinity. Mineral resource potential for locatable commodities is expected to be low. 


\section{REFERENCES:}

Green, G.N., 1992, The digital geologic map of Colorado in ARC/INFO format: U.S. Geological Survey Open-File Report 92-507.

Johnson, B.R., and Bruce, R.M., 1991, Geologic map of parts of the Twin Peaks and Blanca Peak quadrangles, Alamosa, Costilla, and Huerfano Counties, Colorado: U.S. Geological Survey Miscellaneous Field Studies Map MF-2169, scale 1:24,000.

Lozano, Efraim, 1965, Geology of the southwestern Garo area, South Park, Park County, Colorado: Colorado School of Mines M.S. thesis, 115 p.

Tweto, Ogden, 1974, Reconnaissance geologic map of the Fairplay West, Mount Sherman, South Peak, and Jones Hill 7-1/2 minute quadrangles, Park, Lake, and Chaffee Counties, Colorado: U.S. Geological Survey Miscellaneous Field Studies Map MF-555, scale $1: 62,500$.

Tweto, Ogden, 1979, Geologic map of Colorado: U.S. Geological Survey Special Geologic Map, scale 1:500,000.

Tweto, Ogden, Moench, R.H., and Reed, J.C., Jr., 1978, Geologic map of the Leadville $1^{\circ} \mathrm{X} 2^{\circ}$ quadrangle, northwestern Colorado: U.S. Geological Survey Miscellaneous Investigations Series Map I-999, scale 1:250,000.

Wilson, A.B., 2003, Databases and simplified geology for mineralized areas, claims, mines and prospects in Colorado: U.S. Geological Survey Open-File Report 03-090.

Wobus, R.A., and Epis, R.C., 1978, Geologic map of the Florissant 15-minute quadrangle, Park and Teller Counties, Colorado: U.S. Geological Survey Miscellaneous Investigations Series Map I-1044, scale 1:62,500.

\section{LIST OF ATTACHMENTS:}

A. Exhibits A and B. Legal description of Non-Federal and Federal land considered in this exchange (provided by U.S. Forest Service).

B. Report request (provided by U.S. Forest Service).

C. Simplified geologic map showing location of Federal parcel and non-Federal parcels A-1 to A-3. (After Tweto, 1979; Green, 1992; Wilson, 2003).

D. Simplified geologic map showing location of non-Federal parcels A-1 to A-3. (After Tweto, 1979; Green, 1992; Wilson, 2003). 


\section{Attachment A. Exhibits A and B (provided by U.S. Forest Service)}

\section{EXHIBIT A}

Property that the Non-Federal Party will consider exchanging:

$6^{\text {th }}$ PM, Park County, Colorado

Parcel A-1 (Round Hill Parcel)

Township 10 South, Range 78 West

Section 35: $S^{1 / 2}$

Section 36: W $1 / 2$ SW $1 / 4$

Containing 400 acres, more or less

Parcel A-2 (Harrington Ranch Parcel)

Township 12 South, Range 77 West

Section 10: NE1/4NE1/4, S1/2NE1/4, SE1/4NW1/4

Containing 160 acres, more or less

6th PM, Douglas County, Colorado

Parcel A-3 - (Westcreek Parcels)

Township 10 South, Range 70 West

Section 26: S1/2SE1/4NE1/4,

Northwestern Lode Mining Claim, Mineral Survey No. 10951, embracing a portion of Section 23,

Township 10 South, Range 70 West in the Tyler Mining District.

Containing 30.32 acres, more or less

6th PM Huerfano County, Colorado

Parcel A-4 (Huerfano Claims)

All of the following patented mining claims in the Sierre Blanca Mining District embraced in

Township 28 South, Range 72 West \& Range 73 West

Eagle Plume Lode, MS No. 7086; Hawkins Lode, MS 7087: Highline No.1, MS 13261A; Coronado

No. 1, MS 13261A; Coronado No. 2, MS 13261A; Copper King, MS 13261 A; Victor, MS 13261A;

Coronado Mili Site, MS 13261B; Skyscraper, MS 13443; Slide, MS 13443; Pilot, MS 13443; Ariel.

MiS 13443

Containg 83.417 acres, more or less

\section{EXHIBIT B}

Property that the U.S. Forest Service will consider exchanging: (Elevenmile Parcel)

$66^{\text {th }}$ PM, Park County, Colorado

Township 13 South, Range 72 West

Section 17: Lots 4,9 \& 10

Section 20: Lots $3,4,5,8,9,10,11$, W $1 \frac{1}{2}$ Lot 13 , Lots 15 \& 16, W $1 / 2$ Lot 18

Section 29: Lots 5, 6, 7 \& 10

Containing 476.34 acres, more or less 


\section{Attachment B. Report request (provided by U.S. Forest Service).}

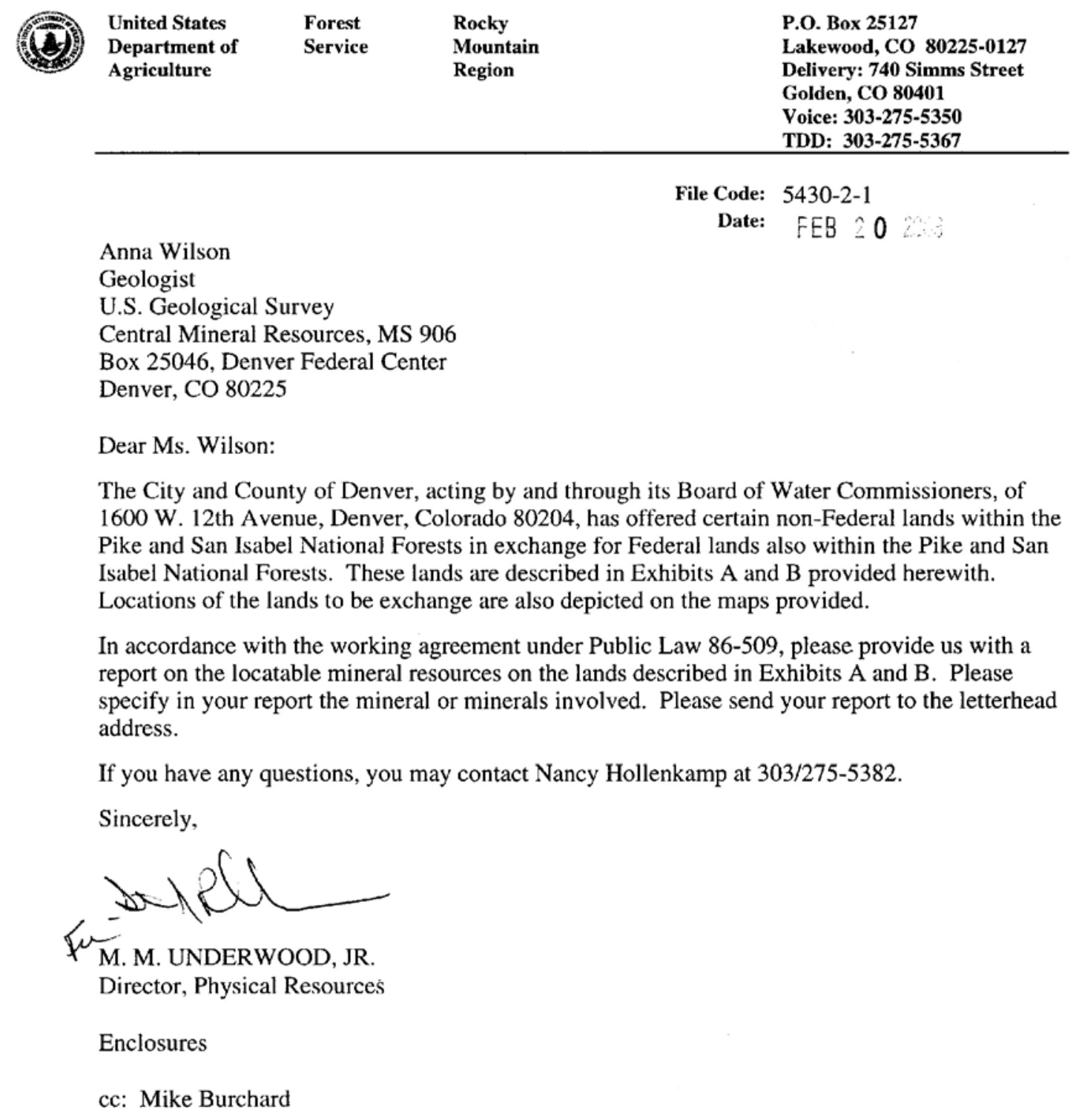


Attachment C. Simplified geologic map showing location of Federal parcel and non-Federal parcels A-1 to A-3. (After Tweto, 1979; Green, 1992; Wilson, 2003).

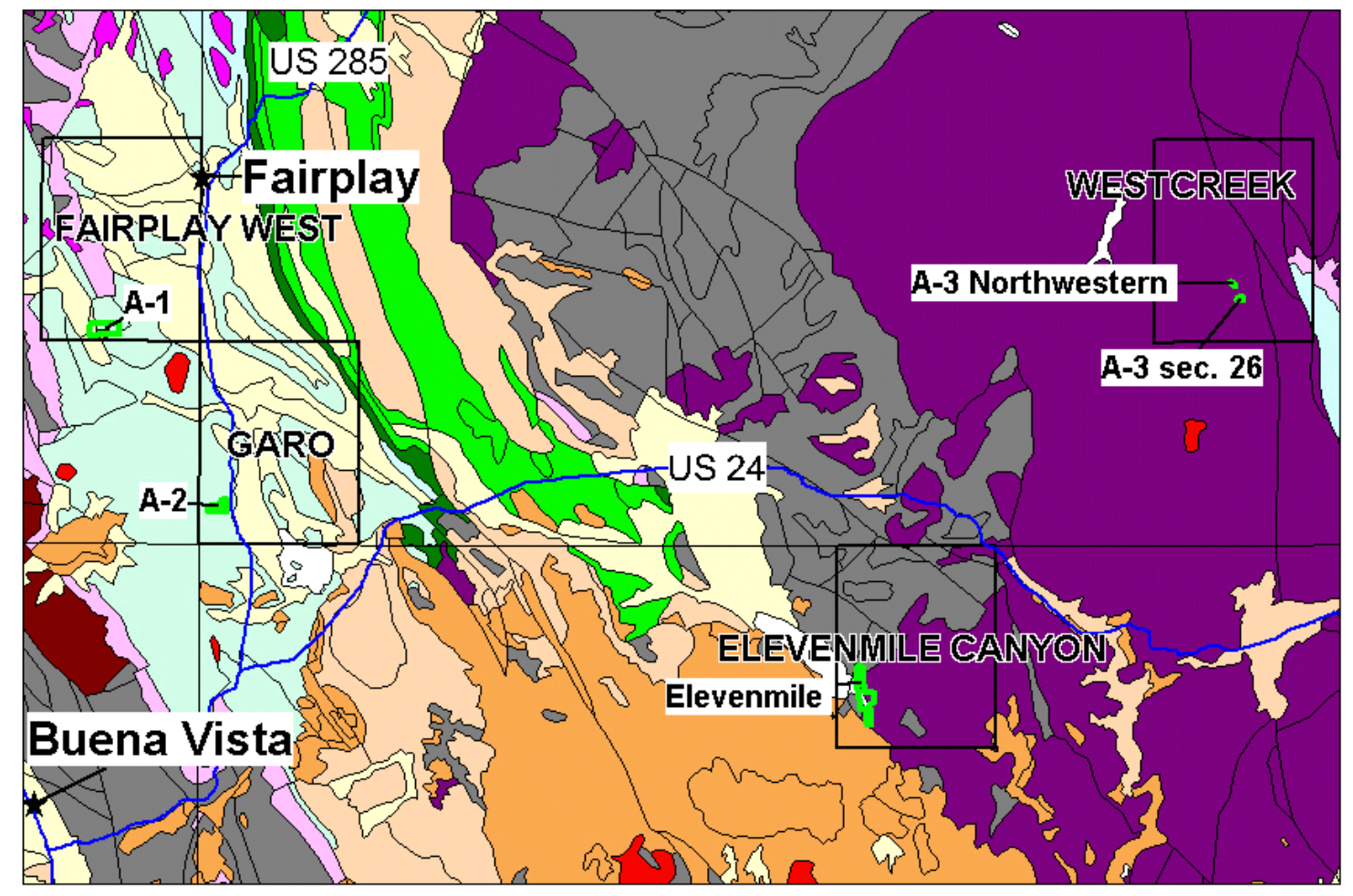


Attachment D. Simplified geologic map showing location of non-Federal parcel A-4. (After Tweto, 1979; Green, 1992; Wilson, 2003).

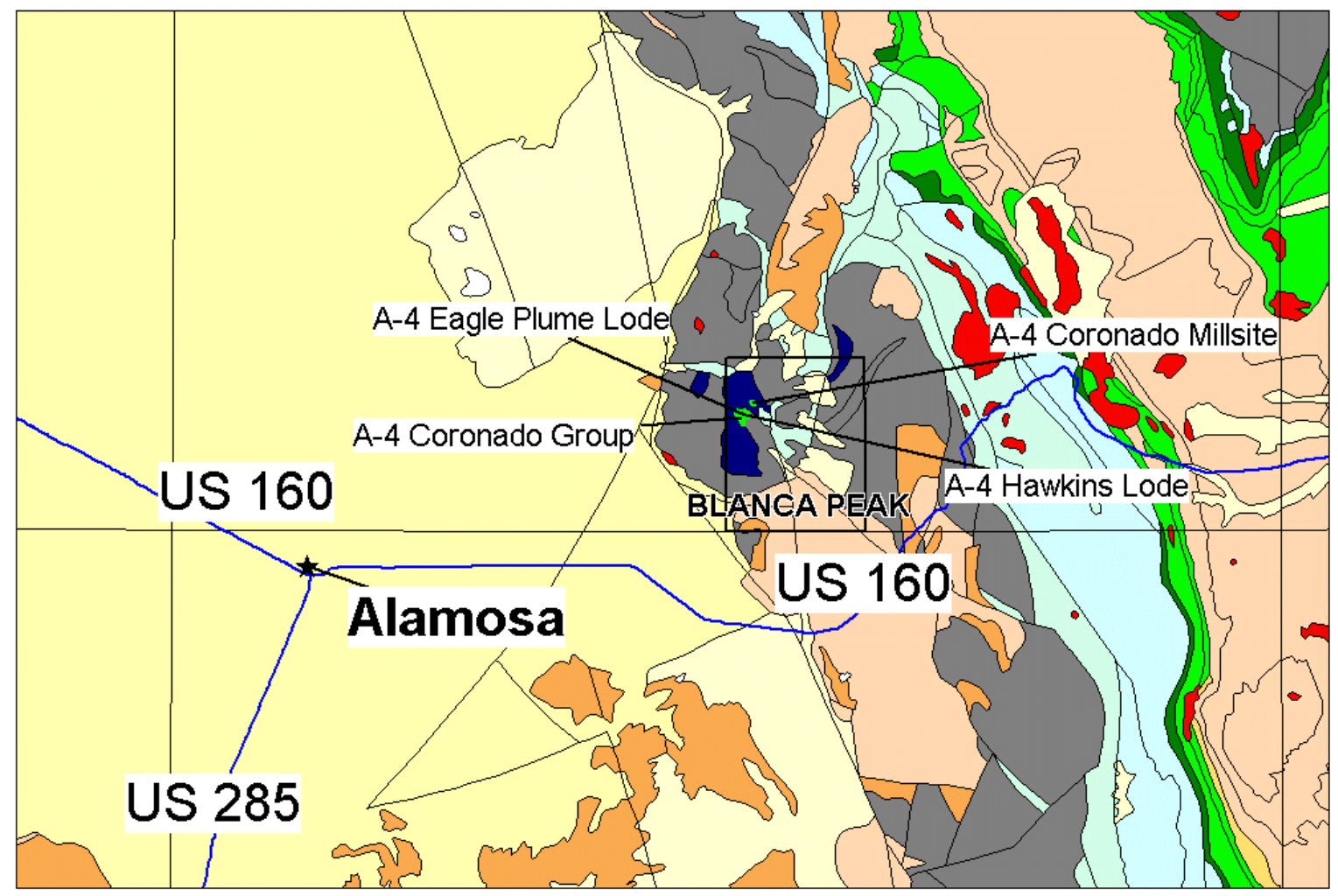




\author{
LOCATABLE MINERAL REPORT FOR THE \\ LAUGHLIN PARK (Smith) LAND EXCHANGE OFFER, \\ SAN JUAN AND PIKE/SAN ISABEL NATIONAL FORESTS, \\ ARCHULETA, CHAFFEE, AND EAGLE COUNTIES, COLORADO
}

By

Anna B. Wilson

U.S. Geological Survey

Administrative Report

September 30, 2004

The following report is based on information contained in USGS mineral resource and commodity files, mineral information databases (MRDS and MAS), and on reports and maps available in the USGS library. These data are occasionally augmented with unpublished documents, personal communications, and professional experiences. No field studies or on-site visits were performed in preparing this report. Emphasis is primarily on locatable mineral resources. Leasable and salable resources are covered only if they appear in the above documents. Mineral resource assessments are subjective: the opinions expressed herein are entirely those of the author. 


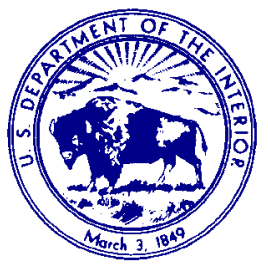

U.S. Department of the Interior

U.S. Geological Survey

Box 25046, MS 964

Denver Federal Center

Denver CO, 80225

(303) 236-5593

awilson@usgs.gov

September 30, 2004

Mr. Randall Karstaedt

Director, Physical Resources

U.S. Forest Service

P.O. Box 25127

Lakewood, CO 80225-0127

Dear Mr. Karstaedt:

This report is in response to your August 12 request for information on locatable mineral resources in a land exchange proposal in which Thomas H. And Margie E. Smith have offered certain non-Federal lands within the San Juan and Pike/San Isabel National Forests in exchange for Federal lands within the San Juan National Forest.

In accordance with our long-term working agreement under Public Law 86-509, we are providing you with a report on the locatable mineral resources on the lands described in Exhibits A and B, which were included with your request. These lands comprise approximately 594 acres in Archuleta, Chaffee, and Eagle Counties, Colorado.

Sincerely yours,

Anna B. Wilson, Geologist

Mineral Resources Program, Central Region

Copies: $\quad$ C.J. Nutt

N. Hollenkamp

J.S. Dersch 
For the legal location description of lands considered for exchange, refer to Exhibits A and B in Attachments A and B. The report request is Attachment C. Attachments D and E are simplified geologic maps showing the approximate locations of the Federal and non-Federal parcels.

\section{$\underline{\text { Non-Federal Lands }}$}

$\underline{\text { Parcel A "Laughlin Park" }}$ Jackson Mountain 1:24,000, Chromo 1:62,500, Antonito 1:100,000, Durango 1:250,000 quadrangles.

The Laughlin Park parcel is east of Jackson Mountain (Attachment D). There does not appear to be any detailed geologic mapping available for this area; the only geologic map is the Durango 1:250,00-scale map (Steven and others, 1974). Although the parcel is entirely contained within Tertiary intrusive rock (intermediate to felsic composition, approx. 40-20 Ma), it does not appear that any mineralization is associated with the intrusion (Van Loenen and Gibbons, 1997, p. 27). Mapping does not reveal the form of the intrusion.

There are no mines or prospects in the vicinity (Wilson, 2003) nor are there any associated with the intrusion. Due to lack of geologic indications of mineralization, the resource assessment of the San Juan National Forest did not include this parcel in the area deemed "favorable" for mineral resource potential (Van Loenen and Gibbons, 1997). Therefore, mineral resource potential for locatable minerals is considered to be low.

\section{Parcel B "Spiler Canyon"}

Serviceberry Mountain and Edith 1:24,000, Antonito 1:100,000, Durango 1:250,000 quadrangles.

The Spiler Canyon parcel is between 1-1/2 and 2 mi east of Blanca. There does not appear to be any detailed geologic mapping available in this area; the only geologic map is the Durango 1:250,00-scale map (Steven and others, 1974, Attachment D). Most of the parcel is in Upper Cretaceous Mesaverde Formation, an interbedded thin sandstone and dark-gray clay shale (Steven and others, 1974). The extreme northeast edge of the parcel may be cut by a northweststriking fault. Exposed to the northeast of the fault is Upper Cretaceous Lewis Shale, a dark-gray shale containing thin sandstone beds near the top, and rusty-weathering concretions in the lower part (Steven and others, 1974). Where not in fault contact, Lewis Shale overlies the Mesaverde Formation, but the exact relationships are not indicated on the map.

There are no mines or prospects in the vicinity (Wilson, 2003). Based on lack of indication of mineralization, the resource assessment of the San Juan National Forest did not include the area surrounding this parcel in an area of "favorable" mineral resource potential (Van Loenen and Gibbons, 1997). Therefore, mineral resource potential for locatable minerals is considered to be low. 
Parcel C "Chaffee County Mining Claims"

Mt. Elbert 1:24,000, Leadville 1:100,000, Leadville 1:250,000 quadrangles.

The claims in this parcel are located near the head of Willis Gulch in the main body of the Twin Lakes pluton (Attachment E). The pluton is Paleocene and primarily composed of porphyritic biotite granodiorite (Fridrich and others, 1998; Tweto and others, 1978). Early Proterozoic Kroenke Granodiorite crops out in the area, and there are local Quaternary surficial deposits. Note that the locations of the claims shown in Attachment $\mathrm{C}$ are approximate.

Several molybdenum prospects in the vicinity, as well as the claims in the parcel, are outside of known productive mining districts (Wilson, 2003). The parcels are a little more than $1 \mathrm{mi}$ northwest of the Winfield district and about $31 \frac{1}{2}$ mi south of the Twin Lakes district. The resource assessment of the San Isabel National Forest places this area in a geologic terrane that was assigned high mineral resource potential with certainty level C (moderately high certainty) for disseminated and stockwork deposits in plutonic rocks containing molybdenum and copper (Taylor and others, 1984). Certainty was established based on data that suggest the presence of a geologic environment with resource potential, but without enough data to establish that resourceforming processes had occurred. By virtue of these being patented mining claims, at the time the patent was granted the claim was judged to be economically viable. However, lack of productive mines in the immediate vicinity would suggest that any deposit that may occur in this area is currently subeconomic.

\section{Federal Lands}

"Job Corps/Oak Brush Hill"

Pagosa Springs 1:24,000, Durango 1:100,000, Durango 1:250,000 quadrangles.

Most of the Job Corps/Oak Brush Hill parcel is mapped (Hail, 1971; Steven and others, 1974, Attachment D) as the lower part of the Upper Cretaceous Mancos Shale. The western part of the parcel is mapped as Lower Cretaceous Dakota Sandstone and Burro Canyon Formation, undifferentiated. The Dakota disconformably overlies the Burro Canyon. Dakota Sandstone is described as light gray to brown sandstone with interbedded siltstone and carbonaceous shale, commonly with a chert-pebble conglomerate or conglomeratic sandstone at the base. The Burro Canyon Formation is lenticular chert-pebble conglomerate and green and gray claystone.

The area immediately to the south of the parcel (Oak Grove Ranch) was prospected for optical calcite in the 1930s and 1940s. However, at this location and several others farther away (including Seavy Ranch, Attachment D)"the calcite crystals uncovered at the surface and in pits, trenches, and shafts were found to be unsuitable for optical purposes because of fracturing and color in the crystals" (Deshayes and Wilson, 1949, p. 2). Based on lack of indication of mineralization, the resource assessment of the San Juan National Forest did not include the area surrounding this parcel in an area of "favorable" mineral resource potential (Van Loenen and Gibbons, 1997). Therefore, mineral resource potential for locatable minerals is considered to be low. 
"Dutton"

Pagosa Springs 1:24,000, Durango 1:100,000, Durango 1:250,000 quadrangles.

Only 1/4 mi to the north of the Job Corps/Oak Brush Hill parcel, the Dutton parcel is entirely in Mancos Shale (Attachment D). The southwest half of this parcel is in the lower part of the formation, the northeast half is in the upper part of the formation.

Based on lack of indication of mineralization, the resource assessment of the San Juan National Forest did not include the area surrounding this parcel in an area of "favorable" mineral resource potential (Van Loenen and Gibbons, 1997). Therefore, mineral resource potential for locatable minerals is considered to be low.

\section{$\underline{\text { REFERENCES: }}$}

Deshayes, E.V., and Wilson, S.R., 1949, Investigation of Colorado Minerals Co. calcite deposits, Archuleta and Hinsdale Counties, Colo[rado]: U.S. Bureau of Mines Report of Investigations 4554, 7 p.

Fridrich, C.J., DeWitt, Ed, Bryant, Bruce, Richard, Steve, and Smith, R.P., 1998, Geologic map of the Collegiate Peaks Wilderness Area and the Grizzly Peak Caldera, Sawatch Range, central Colorado: U.S. Geological Survey Miscellaneous Investigations Series Map I2565, scale 1:50,000.

Hail, W.J., Jr., 1971, Geologic reconnaissance map of the Chris Mountain and Pagosa Springs quadrangles, Archuleta County, Colorado: U.S. Geological Survey Open-File Report 71142.

Steven, T.A., Lipman, P.W., Hail, W.J., Jr., Barker, Fred, and Luedke, R.G., compilers, 1974, Geologic map of the Durango quadrangle, southwestern Colorado: U.S. Geological Survey Miscellaneous Investigations Series Map I-764, scale 1:250,000.

Tweto, Ogden, Moench, R.H., and Reed, J.C., Jr., 1978, Geologic map of the Leadville $1^{\circ} \mathrm{X} 2^{\circ}$ quadrangle, northwestern Colorado: U.S. Geological Survey Miscellaneous Investigations Series Map I-999, scale 1:250,000.

Van Loenen, R.E., and Gibbons, A.B., 1997, Mineral resource potential and geology of the San Juan National Forest, Colorado: U.S. Geological Survey Bulletin 2127, 140 p.

Wilson, A.B., 2003, Databases and simplified geology for mineralized areas, claims, mines and prospects in Colorado: U.S. Geological Survey Open-File Report 03-090. 


\section{LIST OF ATTACHMENTS:}

A. Exhibit A. Legal description of non-Federal land considered in this exchange (provided by U.S. Forest Service).

B. Exhibit B. Legal description of Federal land considered in this exchange (provided by U.S. Forest Service).

C. Report request (provided by U.S. Forest Service).

D. Geologic map showing location of Federal parcels and non-Federal parcels A and B and mines and prospects. (After Steven and others, 1974; Wilson 2003).

E. Geologic map showing location of non-Federal parcel C. (After Fridrich and others, 1998; Wilson, 2003). 


\title{
Attachment A. Exhibit A (provided by U.S. Forest Service)
}

\author{
EXHIBIT A
}

Property that the Non-Federal Party will consider exchanging:

Parcel A: Laughlin Park

Township 36 North, Range 1 West, NMPM, Archuleta County, CO

Sec. 16, W1/2E1/2SE1/4SW1/4,

$\mathrm{E} 1 / 2 \mathrm{~W} 1 / 2 \mathrm{SE} 1 / 4 \mathrm{SW} 1 / 4$,

E1/2SW1/4NE1/4SW1/4,

NW1/4NW1/4SE1/4SW1/4,

$\mathrm{W} 1 / 2 \mathrm{~W} 1 / 2 \mathrm{NE} 1 / 4 \mathrm{SW} 1 / 4$,

$\mathrm{E} 1 / 2 \mathrm{E} 1 / 2 \mathrm{NW} 1 / 4 \mathrm{SW} 1 / 4$,

NW1/4SE1/4NW1/4SW $1 / 4$,

$\mathrm{W} 1 / 2 \mathrm{NE} 1 / 4 \mathrm{NW} 1 / 4 \mathrm{SW} 1 / 4$,

SW1/4SE1/4SW1/4NW1/4,

NE1/4NW1/4NW1/4SW1/4,

SE1/4SW1/4SW1/4NW1/4.

Totaling 62.5 acres, more or less.

Parcel B: Spiler Canyon

Township 33 North, Range 1 East, NMPM, Archuleta County, CO

Sec. 6, SE1/4NW1/4, NW1/4SE1/4, E1/2SW1/4

Totaling 160 acres, more or less.

Parcel C: Chaffee County Mining Claims

Township 12 South, Range 81 West, $6^{\text {th }}$ PM, Chaffee County, CO

portions of Secs. $16 \& 17$

Keystone, Keystone No. 1, and Little Annie, U.S. Survey No. 18504, located in the Hope Mining District; and Condor, U.S. Survey No. 3493, located in the Lake Creek Mining District.

Totaling 41.32 acres, more or less.

All totaling 263.82 acres, more or less. 


\section{Attachment B. Exhibit B (provided by U.S. Forest Service).}

\section{EXHIBIT B}

Property that the U.S.D.A. Forest Service will consider exchanging:

Job Corps/Oak Brush Hill

Township 36 North, Range 2 West, New Mexico Principal Meridian, Archuleta County, Colorado

Sec. 31, SE1/4 SE1/4;

Sec. 32, SW1/4 SW1/4.

Township 35 North, Range 2 West, New Mexico Principal Meridian, Archuleta County, Colorado

Sec. 5, Lot 4

Sec. 6, Lot 1;

SE1/4 NE1/4,

NE1/4 SE1/4,

SW1/4 NE1/4, and,

a portion of Lot $2(\mathrm{~S} 1 / 2 \mathrm{NW} 1 / 4 \mathrm{NE} 1 / 4)$.

Dutton

Township 36 North, Range 2 West, NMPM, Archuleta County, CO.,

Sec. 32, SW1/4 NW 1/4

All totaling 330.27 acres, more or less. 


\section{Attachment C. Report Request (provided by U.S. Forest Service).}

\begin{tabular}{llll} 
United States & Forest & Rocky & P.O. Box 25127 \\
$\begin{array}{l}\text { Department of } \\
\text { Agriculture }\end{array}$ & Service & Mountain & Lakewood, CO 80225-0127 \\
& & Region & Delivery: 740 Simms Street \\
& & Golden, CO 80401 \\
& & Voice: 303-275-5350 \\
& & TDD: $303-275-5367$ \\
\hline
\end{tabular}

File Code: $5430-2-1$

Anna Wilson

AUG 122004

Geologist

Central Mineral Resources

U.S. Geological Survey MS 905

Box 25046, Denver Federal Center

Lakewood, CO 80225

Dear Ms. Wilson:

Thomas H. and Margie E. Smith of 1701 East $147^{\text {th }}$ Street, Kansas City, Missouri 64146, has offered certain non-Federal lands within the San Juan and Pike/San Isabel National Forests, in exchange for Federal lands within the San Juan National Forest. These lands are generally described in Exhibits A and B enclosed herewith. The lands to be exchanged are depicted on the maps also provided.

In accordance with the working agreement under Public Law 86-509, please provide a report on the locatable mineral resources on the lands described in Exhibits A and B. Please specify in your report the mineral or minerals involved. Please send your report to the letterhead address.

If you have any questions, you may contact Nancy Hollenkamp at (303) 275-5382.

Sincerely,

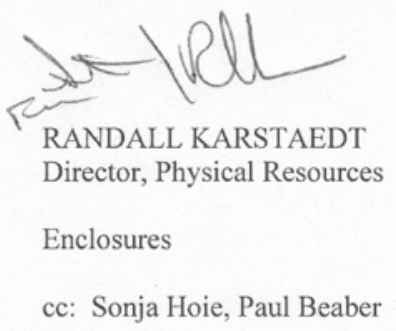


Attachment D. Geologic map showing location of non-Federal parcels A and B (Laughlin Park and Spiler Canyon), and Federal parcels (Job Corps /Oak Brush Hill and Dutton). (After Steven and others, 1974; Wilson, 2003). Rock units of interest include: Ti, Tertiary intrusive rocks; Kl, Upper Cretaceous Lewis Shale; Kmv, Upper Cretaceous Mesa Verde Formation; Km, Upper Cretaceous Mancos Shale, undivided; Kmu, Mancos Shale, upper part; Kml, Mancos Shale, lower part; Kdb, Upper and Lower Cretaceous Dakota Sandstone and Burro Canyon Formation.

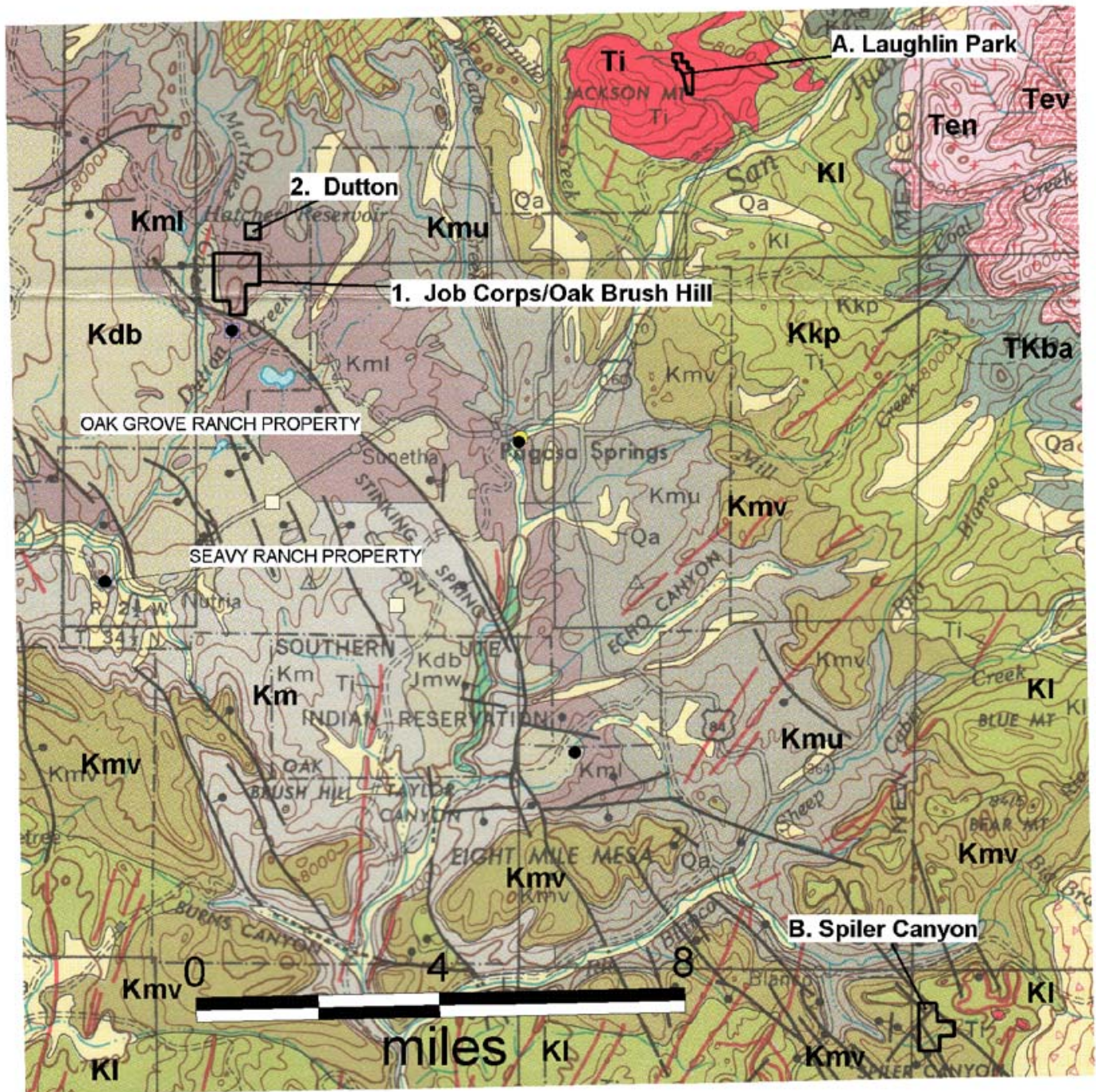


Attachment E. Geologic map showing location of non-Federal parcels C. (After Fridrich and others, 1998; Wilson, 2003). Rock units of interest include: Qs, Quaternary surficial deposits; Qg, Quaternary glacial deposits; Tt, Paleocene Twin Lakes Pluton, main body; Xk, Early Proterozoic Kroenke Granodiorite; and Xd, Early Proterozoic Denny Creek Granodiorite, main body.

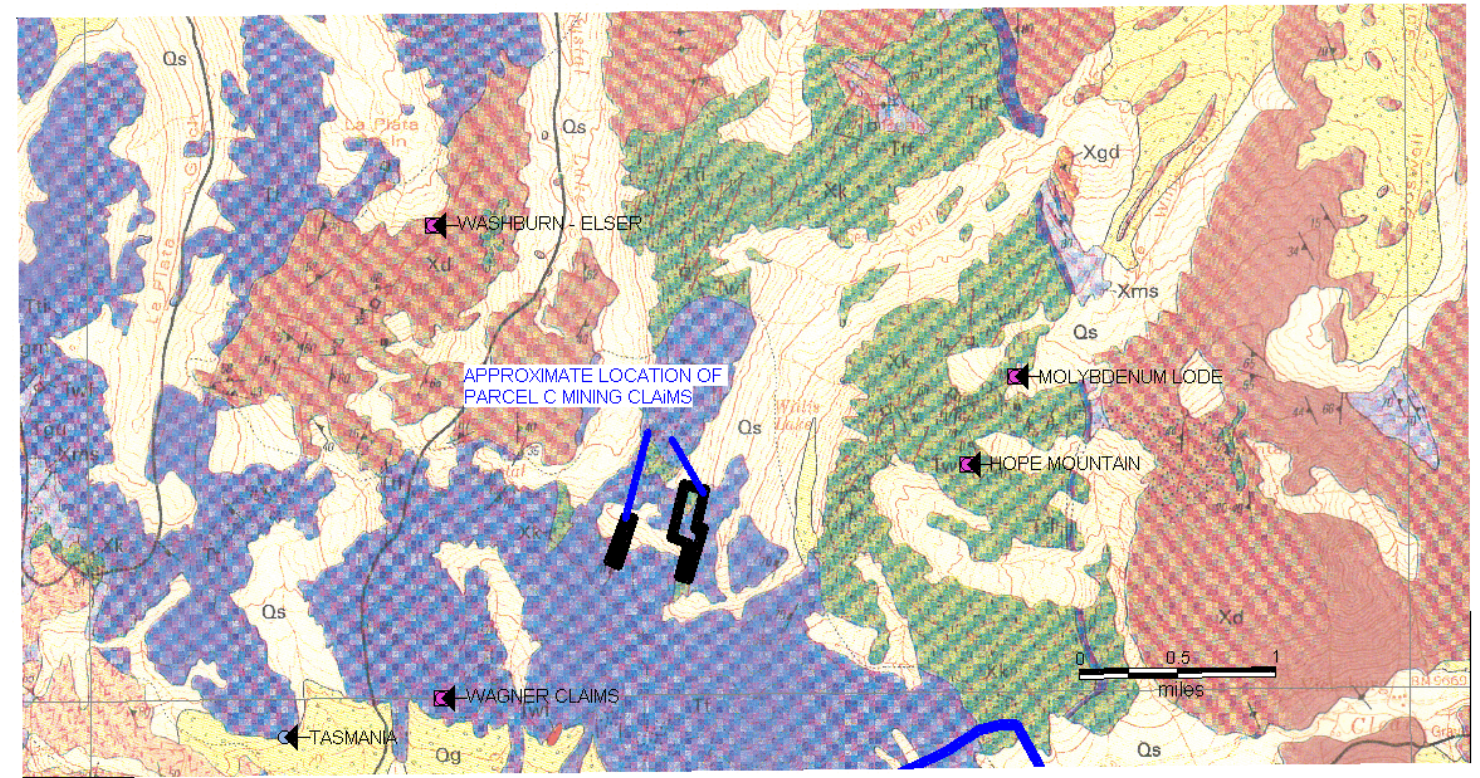




\title{
LOCATABLE MINERAL REPORT FOR THE FISH CREEK LAND EXCHANGE OFFER, SAN JUAN NATIONAL FOREST, SAN JUAN, LA PLATA, AND DOLORES COUNTIES, COLORADO
}

\author{
By
}

Anna B. Wilson

U.S. Geological Survey

Administrative Report

April 25, 2005

The following report is based on information contained in USGS mineral resource and commodity files, mineral information databases (MRDS and MAS), and on reports and maps available in the USGS library. These data are occasionally augmented with unpublished documents, personal communications, and professional experiences. No field studies or on-site visits were performed in preparing this report. Emphasis is primarily on locatable mineral resources. Leasable and salable resources are covered only if they appear in the above documents. Mineral resource assessments are subjective: the opinions expressed herein are entirely those of the author. This report has not been reviewed for stratigraphic nomenclature. 


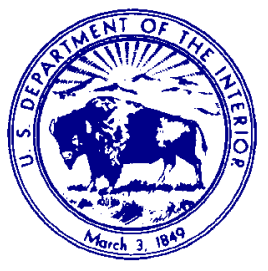

\section{U.S. Department of the Interior}

\section{U.S. Geological Survey}

Box 25046, MS 964

Denver Federal Center

Denver CO, 80225

303) 236-5593

awilson@usgs.gov

April 25, 2005

Mr. Randall Karstaedt

Director, Physical Resources

U.S. Forest Service

P.O. Box 25127

Lakewood, CO 80225-0127

Dear Mr. Karstaedt:

This report is in response to your February 24 request for information on locatable mineral resources in a land exchange proposal in which Morgan Land \& Cattle Partners, Ltd., and Harvey Peel, represented by Western Land Group, have offered certain non-Federal lands within the San Juan National Forest in exchange for Federal lands also within the San Juan National Forest.

In accordance with our long-term working agreement under Public Law 86-509, we are providing you with a report on the locatable mineral resources on the lands described in Exhibits $\mathrm{A}$ and B, which were included with your request. These lands comprise approximately 120 acres in San Juan, La Plata, and Dolores Counties, Colorado.

Sincerely yours,

Anna B. Wilson, Geologist

Mineral Resources Program, Central Region

Copies: $\quad$ C.J. Nutt

N. Hollenkamp

J.S. Dersch 
For the legal location description of lands considered for exchange exclusive of Reservations, Outstanding Rights, or other restrictions, refer to Exhibits A and B in Attachments A and B. The report request is Attachment C. Attachments D and $\mathrm{E}$ are geologic maps showing the approximate locations of the non-Federal parcels.

\section{$\underline{\text { Non-Federal Lands }}$}

Parcels 1 "Wall Street, Cherokee, Hailstone, and Jennie Lind lode mining claims" Parcel 2 "Sebastapool lode mining claim, and Parcel 3 "Oregon, Emma, and Galena lode mining claims"

Ophir 1:24,000, Silverton 1:100,000, Durango 1:250,000 quadrangles.

All the claims in Parcels 1 and 3 are in the vicinity of Ice Lake basin, south of Ophir. The geology was mapped (Attachment D) and the formations described by Luedke (1996) at 1:24,000-scale. Eocene Telluride Conglomerate (unit Tte) is the oldest formation exposed in any of the parcels. The conglomerate and minor sandstone contains pebble to cobble clasts in an arkosic and sandy matrix. Unconformably overlying the conglomerate is the Oligocene San Juan Formation (unit Tsj) of the Sapinero Mesa Tuff. The San Juan Formation is a 210-610 mthick pile of reworked lahar or mudflow breccia intermixed with sandy tuff and tuff conglomerate. In the vicinity of the Sebastapool claim, the San Juan Formation is extensively hydrothermally altered. Resting on the top of the uneven erosion surface on the San Juan Formation are flow breccias, tuffs, and flows of the Burns Member (unit Tsb) of the Silverton Volcanics. Oligocene ash-flow tuff (unit $\mathrm{Tt}_{1-7}$ ) overlies the Burns Member, and in this area, it is hydrothermally altered to quartz-sericite-clay, and locally to quartz-clay acid-sulfate minerals. Numerous veins or mineralized faults or fissures are present in the Burns Member and in the ash-flow tuff. Small dikes of Oligocene dacite (unit Tid) intrude the Burns Member.

Wall Street claim is in the Burns Member on the lowest slopes, and in hydrothermally altered ash-flow tuff at the higher elevations.

Hailstone claim is in the Burns Member, roughly parallel to one group of mineralized veins or fissures and perpendicular to both dacite dikes and another mineralized vein or fissure.

Cherokee claim is in the Burns Member parallel to a mineralized vein or fissure.

Jennie Lind claim parallels a vein in the Burns Member in the underlying San Juan Formation of the Sapinero Mesa Tuff.

Sebastapool claim is entirely in hydrothermally altered San Juan Formation.

Oregon, Emma, and Galena claims are in the Burns Member and San Juan Formations, overlying Eocene Telluride Conglomerate.

With the exception of the Sebastapool property, all of the claims are in the Ice Lake mining district, a description of which is in Neubert and others (1992, p. 190-196). All of the properties are in an area assessed as being favorable for the presence of polymetallic replacement and skarn deposits (hydrothermal deposits of $\mathrm{Ag}, \mathrm{Pb}, \mathrm{Zn}$, and $\mathrm{Cu}$ sulfide minerals in massive lenses, pipe-shaped bodies, and associated veins in limestone, dolostone, or other soluble strata that are replaced by ore) and for Creede-type epithermal veins hosted in Tertiary 
volcanic terrane. Each of the patented claims has high potential for the above deposit-types. However, the very small size of the claims and lack of apparent mining in the area, in spite of intense prospecting, suggests that any of these deposits would be small and likely not economic (at current metal prices at the time of this report). Interestingly, these claims are all in an area assigned "favorable" potential for oil and gas accumulations of the Silverton Delta play. In this play conventional accumulations occur in permeable deltaic sandstones (that are equivalents of the Hermosa Group) along the flank of the Paradox Basin (Van Loenen and Gibbons, 1997).

Additionally, the Sebastapool claim is in an area assessed as favorable for stockwork molybdenum (and may also contain tin, tungsten, and bismuth) and for porphyry coppermolybdenum deposits (and may also contain Ag and Au) (Van Loenen and Gibbons, 1997). This hydrothermally-altered area, which includes the Sebastapool claim, is known as the Mount Moly system. It is a subeconomic $\sim 26$ Ma porphyry molybdenum (+/- copper) system with strongly developed quartz-sericite-pyrite alteration and disseminated pyrite (D.J. Bove, USGS, 3/16/05, oral commun.).

Parcel 4 "Republic and Aztec lode mining claims"

Columbine Pass 1:24,000, Silverton 1:100,000, Durango 1:250,000 quadrangles.

Geology in Missouri Gulch in the vicinity of the Republic and Aztec claims is mapped as 1,350 $\mathrm{Ma} \pm 50$ Middle Proterozoic Trimble Granite stock (Barker, 1969, p. 27-28.) (unit Ytr, Attachment E, after Schmitt and Raymond, 1977). The Trimble Granite stock intrudes approximately $1460 \mathrm{Ma}$ Eolus Granite, which forms two composite batholiths (Barker, 1969, p. 25-27). Veins appear to be related to the hypabyssal granite (unit Tio) and rhyolite porphyry (unit Tiy) plug and related rocks, more than a half-mile from the northern end of the claim block, in Chicago Basin (Schmitt and Raymond, 1977; Neubert and others, 1992). The mining claims parallel a north-northeast striking fracture or vein (Schmitt and Raymond, 1977). It is not clear from the juxtaposition of the geologic map with the claim map if the claim follows the vein at the surface or if the data layers are offset due to scale or projection issues (Attachment E).

The claims are in an area assessed as favorable for the presence of polymetallic veins, skarns, and replacement deposits adjacent to stockwork molybdenum or molybdenum-mineralized porphyry stocks (Van Loenen and Gibbons, 1997). It is also assessed as favorable for vein uranium deposits related to $1.4 \mathrm{Ga}$ and 10-Ma granites intruding Middle and (or) Early Proterozoic rocks (Van Loenen and Gibbons, 1997). The entire Needle Mountains mining district may have produced a total of $\$ 12,500$, mostly as gold and silver values, prior to 1900. Known mines in the vicinity of the parcel with recorded production are the Eureka $(\$ 5,000)$, Aetna $(\$ 5,000)$, Pittsburgh $(\$ 2,000)$, and Aztec $(\$ 500)$ (Steven and others, 1969, p. 92). By virtue of being a patented claim, at one time this property was demonstrated to have a viable deposit. Therefore, resource potential is high. However, it is unlikely to be economic under current (2005) conditions. 


\section{Federal Lands}

\section{Parcel 1NF}

Clyde Lake 1:24,000, Dove Creek 1:100,000, Cortez 1:250,000 quadrangles.

The parcel is in the Permian Cutler and Triassic Dolores Formations (Cross and Ransome, 1905; Haynes and others, 1972). The Cutler Formation is a fluvial micaceous arkosic sandstone, siltstone, and conglomerate; the Dolores Formation is fluvial siltstone, sandstone, and shale with a few layers of limestone-shingle conglomerate (Haynes and others, 1972).

The nearest prospects are more than a mile away, but little is known about them. The Little Silver mine in Copper Gulch and the Teaser Prospect (2 miles south of the Little Silver) have too low concentrations of base and precious metals to be considered a resource and did not warrant an economic evaluation (Neubert and others, 1992, p. 26, 28). No resource potential for locatable or salable minerals was identified in the entire township (Van Loenen and Gibbons, 1997).

\section{Parcel 2NF}

Baldy Mountain 1:24,000, Durango 1:100,000, Durango 1:250,000 quadrangles.

No maps or legal description were included with the report request. However, this parcel is in an area for which unpublished reconnaissance mapping by W.J. Hail (USGS, undated) was used for the compilation of the Durango quadrangle (Steven and others, 1974). No other published geologic maps with greater detail could be located.

No favorable resource potential for any locatable commodities is indicated for the entire township (Van Loenen and Gibbons, 1997). Therefore, resource potential for locatable minerals is low. For leasable commodities such as coal, coal-bed gas, natural gas, and oil and gas, there is much favorable ground in the township (Van Loenen and Gibbons, 1997).

\section{LIST OF ATTACHMENTS:}

A. Exhibit A. Legal description of non-Federal land considered in this exchange (provided by U.S.D.A. Forest Service).

B. Exhibit B. Legal description of Federal land considered in this exchange (provided by U.S.D.A. Forest Service).

C. Report request (provided by U.S.D.A. Forest Service).

D. Geologic map showing approximate locations of non-Federal parcels 1-3 and the Ice Lake mineralized area (after Luedke, 1996; Wilson, 2003 and unpublished data, 2005).

E. Geologic map showing approximate location of Aztec and Republic claims in the Needle Mountains mineralized area (Schmitt and Raymond, 1977; Wilson, 2003 and unpublished data, 2005). 


\section{REFERENCES:}

Barker, Fred, 1969, Precambrian geology of the Needle Mountains, southwestern Colorado: U.S. Geological Survey Professional Paper 644-A, p. 35 p.

Cross, Whitman, and Ransome, F.L., 1905, Description of the Rico quadrangle, Colorado: U.S. Geological Survey Geologic Atlas, Folio 130, scale 1:62,500.

Haynes, D.D., Vogel, J.D., and Wyant, D.G., compilers, 1972, Geology, structure, and uranium deposits of the Cortez quadrangle, Colorado and Utah: U.S. Geological Survey Miscellaneous Geologic Investigations Map I-629, scale 1:250,000.

Luedke, R.G., 1996, Geologic map of the Ophir quadrangle, San Juan, San Miguel, and Dolores Counties, Colorado: U.S. Geological Survey Geologic Quadrangle Map GQ-1760, scale $1: 24,000$.

Neubert, J.T., Ellis, C.E., Hannigan, B.J., Jeske, R.E., Martin, C.M., Thompson, J.R., Tuftin, S.E., Wood, R.H., II, and Zelten, J.E., 1992, Mineral appraisal of the San Juan National Forest, Colorado, with a section on Industrial Minerals by Raby, A.G.: U.S. Bureau of Mines Mineral Land Assessment Open-File Report MLA-2-92, 311 p.

Schmitt, L.J., Jr., and Raymond, W.H., 1977, Geology and mineral deposits of the Needle Mountains district, southwestern Colorado: U.S. Geological Survey Bulletin 1434, 40 p.

Steven, T.A., Lipman, P.W., Hail, W.J., Jr., Barker, Fred, and Luedke, R.G., compilers, 1974, Geologic map of the Durango quadrangle, southwestern Colorado: U.S. Geological Survey Miscellaneous Investigations Series Map I-764, scale 1:250,000.

Steven, T.A., Schmitt, L.J., Jr., Sheridan, M.J., and Williams, F.E., 1969, Mineral resources of the San Juan Primitive Area, Colorado: U.S. Geological Survey Bulletin 1261-F, 187 p.

Van Loenen, R.E., and Gibbons, A.B., 1997, Mineral resource potential and geology of the San Juan National Forest, Colorado: U.S. Geological Survey Bulletin 2127, 140 p.

Wilson, A.B., 2003, Databases and simplified geology for mineralized areas, claims, mines and prospects in Colorado: U.S. Geological Survey Open-File Report 03-090. 
Attachment A. Exhibit A-Legal description of non-Federal land considered in this exchange exclusive of Outstanding Rights and Reservations (provided by U.S.D.A. Forest Service).

\section{$\underline{\text { EXHIBIT A }}$}

Property that the Non-Federal Parties will consider exchanging:

\section{New Mexico Principal Meridian, San Juan County, Colorado}

\section{Parcel 1 - Township 41 North, Range 8\&9 West}

The WALL STREET lode mining claim, Survey No. 1725, Ice Lake Mining District, San Juan County, Colorado, according to the patent recorded July 24, 2001 as Reception No. 141250;

The CHEROKEE lode mining claim, Survey No. 11545, Ice Lake Mining District, San Juan County, Colorado, according to the patent recorded July 24, 2001 as Reception No. 141253;

The HAIL STONE lode mining claim, Survey No. 11544, Ice Lake Mining District, San Juan County, Colorado, according to the patent recorded July 24, 2001 as Reception No. 141251; and

The JENNIE LIND lode mining claim, Survey No. 11543, Ice Lake Mining District, San Juan County, Colorado, according to the patent recorded July 24, 2001 as Reception No. 141252.

All totaling 39.385 acres, more or less.

\section{Parcel 2 - Township 41 North, Range 8 West}

SEBASTAPOOL lode mining claim, U.S. Mineral Survey No. 1617, Animas Mining District, San Juan County, Colorado.

All totaling 10.33 acres, more or less.

\section{Parcel 3 - Township 41 North, Range 8 West}

OREGON lode mining claim, U.S. Mineral Survey No. 16725; EMMA lode mining claim, U.S. Mineral Eurvey No. 16725; and GALENA lode mining claim, U.S. Mineral Survey No. 16725; all situate in the Ice Lake or Red Mountain Mining District, San Juan County, Colorado.

All totaling 27.258 acres, more or less

\section{New Mexico Principal Meridian, La Plata County, Colorado}

\section{Parcel 4 - Township 38 North, Range 7 West}

REPUBLIC lode mining claim, Survey No. 14379, Needle Mountain Mining District, La Plata County, Colorado, according to the patent filed for record October 3, 2002 as Reception No. 839553; and

AZTEC lode mining claim, Survey No. 14379, Needle Mountain Mining District, La Plata County, Colorado, according to the patent filed for record October 3, 2002 as Reception No. 839553.

All totaling 20.662 acres, more or less.

Containing an aggregate of 97.635 acres, more or less, in San Juan and La Plata Counties, Colorado. 


\section{Attachment B. Exhibit B--Legal description of Federal land considered in this exchange(provided by U.S.D.A. Forest Service).}

EXHIBIT B

Property that the U.S.D.A. Forest Service will consider exchanging:

\section{New Mexico Principal Meridian, Dolores County, Colorado}

\section{Farcel 1NF. - Township 40 North, Range 13 West}

Section 13: W1/2 of Lot 2.

Ait totaling 21.605 acres, more or less.

(NOTE: A Supplemental Plat will need to be provided by the USDI-Bureau of Land Management prior to closing of this exchange.)

\section{Parcel 2NF - Township 35 North. Range 6 West}

Section 13: a sixty (60) foot wide and approximately 800 foot long non-exclusive access easement, centerline survey to be provided.

Land reservations of the U.S.D.A. Forest Service, exceptions to title and uses to be recognized on Parcel 1NF:

\section{Reservations:}

1. Reserving to the United States a right-of-way thereon for ditches or canals constructed by the authority of the United States Act of August 30, 1890 (26 Stat. 391; 43 U.S.C. 845).

Outstanding Rights: None

Other:

1. Landowner, its successors and assigns, do hereby covenant and agree that there will be no new construction, filling of land, or reductions in water supply on the 2 acres of wetlands and Southwestern Willow Flycatcher habitat identified in Exhibit (to be determined), attached hereto and made a part hereof, unless specific permission is granted by the U.S. Forest Service. Nothing in this covenant shall preclude Landowner, its successors and assigns, from engaging in activities consistent with customary agricultural practices such as grazing, ditch maintenance and repair. This covenant shall remain in effect until such time as the United States determines that this requirement is no longer necessary. Removal of this covenant will be documented by execution and recordation of an appropriate document by the authorized officer. For monitoring purposes, the United States shall be permitted access across lands of the Landowner to inspect the wetlands and Southwestern Willow Flycatcher habitat identified herein.

2. The Transferee shall hold harmless, defend, and indemnify the United States from and against any suit, claim, demand or action, liability, judgment, cost or other fee arising out of any claim for environmental remediation costs, personal injury or property damage that results from, or is in any manner predicated upon the release of any hazardous substance, pollutant or contaminant, or petroleum or petroleum derivative that has been released on the property described as Parcel $1 \mathrm{NF}$ as of the date of convevance. This obligation to hold harmless, defend and indemnify the United States shall survive the conveyance of the property via warranty deed.

3. Special Use Permit issued to Dolores County dated June 2, 1998 for operation and maintenance of the county shops shall be relinquished at or prior to closing of this transaction. 


\section{Attachment C. Report Request (provided by U.S.D.A. Forest Service).}

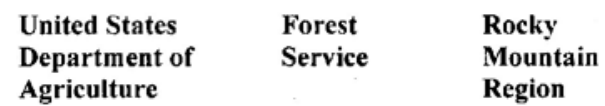

Region
P.O. Box 25127

Lakewood, CO 80225-0127

Delivery: 740 Simms Street

Golden, CO 80401

Voice: 303-275-5350

TDD: $303-275-5367$

File Code: $5430-2-1$

Date:

Anna Wilson

FEB 242005

Geologist

Central Mineral Resources

U.S. Geological Survey, MS 905

Box 25046, Denver Federal Center

Denver, CO 80225

Dear Ms. Wilson:

Morgan Land \& Cattle Partners, Ltd., and Harvey Peel, represented by Western Land Group, Inc., whose address is 507 South Sherman Street, Denver, Colorado (Fish Creek exchange), have offered certain non-Federal lands within the San Juan National Forest, in exchange for Federal lands also within the San Juan National Forest. These lands are generally described in Exhibits $\mathrm{A}$ and $\mathrm{B}$ enclosed herewith. The lands to be exchanged are depicted on the maps also provided.

In accordance with the working agreement under Public Law 86-509, please provide a report on the locatable mineral resources on the lands described in Exhibits A and B. Please specify in your report the mineral or minerals involved. Please send your report to the letterhead address.

If you have any questions, you may contact Nancy Hollenkamp at (303) 275-5382.

Sincerely,

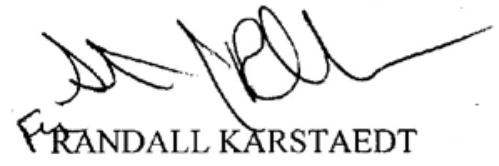

Director, Physical Resources

Enclosures

cc: Cindy Hockelberg 
Attachment D. Geologic map showing approximate locations of non-Federal parcels 1-3 (red outlines) and the Ice Lake mineralized area (blue outline) (after Luedke, 1996; Wilson, 2003 and unpublished data, 2005). Rock units of interest include: Tid, Oligocene Dacite (teal); $\mathrm{Tt}_{1-7}$, Oligocene ash-flow tuff (green); Tsb, Oligocene Burns Member of Silverton Volcanics (pink); Tsj, Oligocene San Juan Formation (orange); and Tte, Eocene Telluride Conglomerate (violet). Mine locations, shown as circles and squares, are from the USGS MAS and MRDS databases, respectively (Wilson, 2003). These mine locations have not been verified and may be unreliable. (Map scale is unknown)

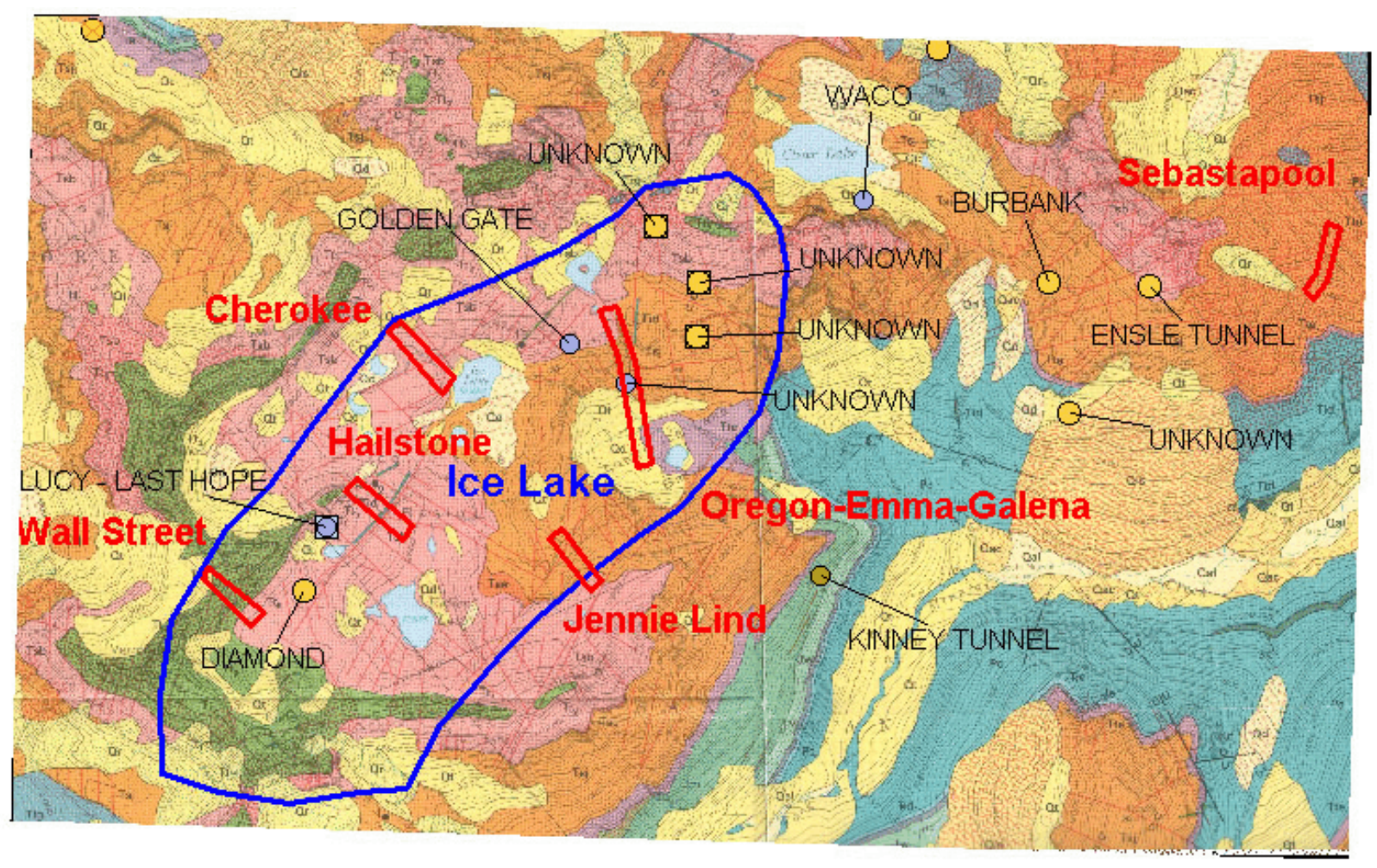


Attachment E. Geologic map showing approximate location of Aztec and Republic claims in the Needle Mountains mineralized area (after Schmitt and Raymond, 1977; Wilson, 2003 and unpublished data, 2005). Rock units of interest include: Tiy, rhyolite porphyry (medium pink); Tio, granite porphyry (light pink); Ytr, Trimble Granite (dark gray); and Ye, Eolus Granite (white). Mine and prospect data are from the MAS (circles) and MRDS (squares) databases (Wilson, 2003). These locations have not been verified and may be unreliable.

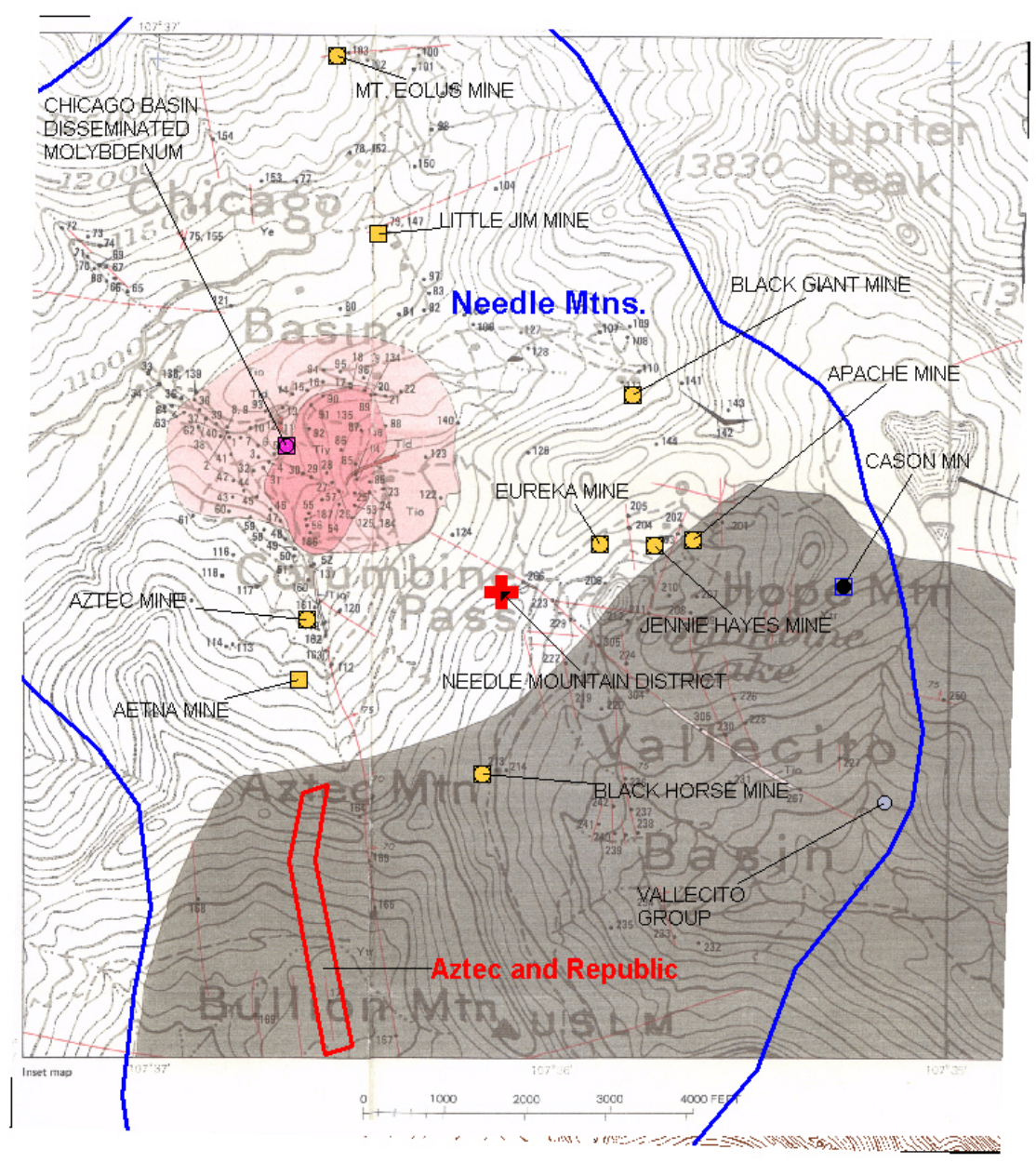




\title{
LOCATABLE MINERAL REPORT FOR THE KENT/LINDSAY EXCHANGE OFFER, UNCOMPAHGRE NATIONAL FOREST, OURAY COUNTY, COLORADO
}

\author{
By \\ Anna B. Wilson \\ U.S. Geological Survey
}

January 19, 2005

The following report is based on information contained in USGS mineral resource and commodity files, mineral information databases (MRDS and MAS), and on reports and maps available in the USGS library. These data are occasionally augmented with unpublished documents, personal communications, and professional experiences. No field studies or on-site visits were performed in preparing this report. Emphasis is primarily on locatable mineral resources. Leasable and salable resources are covered only if they appear in the above documents. Mineral resource assessments are subjective: the opinions expressed herein are entirely those of the author. 


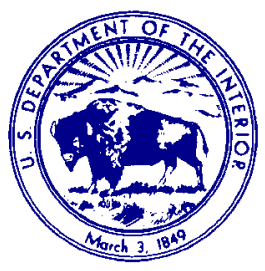

\section{U.S. Department of the Interior}

\section{U.S. Geological Survey}

Box 25046, MS 964

Denver Federal Center

Denver CO, 80225

303) 236-5593

awilson@usgs.gov

January 19, 2005

Mr. Randall Karstaedt

Director, Physical Resources

U.S.D.A. Forest Service

P.O. Box 25127

Lakewood, CO 80225-0127

Dear Mr. Karstaedt:

This report is in response to your January 13 request for information on locatable mineral resources in a land exchange proposal in which Kelvin Kent and Rebecca Lindsay have offered certain non-Federal lands within the Uncompahgre National Forest in exchange for Federal lands also within the Uncompahgre National Forest.

In accordance with the working agreement under Public Law 86-509, we are providing you with a report on the locatable mineral resources on the lands described in Exhibits A and B, which were included with your request. These lands comprise approximately 60.6 acres in Ouray County, Colorado.

Sincerely yours,

Anna B. Wilson, Geologist

Mineral Resources Program, Central Region

Copies:

C.J. Nutt

N. Hollenkamp

J.S. Dersch 
The report request is in Attachment A. For the legal location description of lands considered for exchange, exclusive of reservations and outstanding rights, refer to Exhibits $\mathrm{A}$ and $\mathrm{B}$ in Attachment B. Attachment $\mathrm{C}$ is a geologic map showing the location of the exchange parcels.

\section{$\underline{\text { Non-Federal Lands }}$}

Mt. Sneffels mining claims

Ironton 1:24,000, Silverton 1:100,000, Durango 1:250,000 quadrangles.

The claim block is at the southern end of Imogene Basin near its head, south of Camp Bird. The area is mapped entirely as Miocene Burns Formation (Attachment C) of the Silverton Volcanic Group (Burbank and Luedke, 1964). The formation is described as "medium to dark thick massive flows and flow breccias, tuffs, and fluidal-banded flows of mainly rhyodacitic composition" (Burbank and Luedke, 1964) and is riddled with mineralized faults or fissures.

The parcel appears to be located in the San Juan mineralized area (Wilson and others, 2000; Wilson, 2003) but outside the Sneffels and Red Mountain mining districts (Davis and Streufert, 1990). This area is included in the mineral resource assessment of the Gunnison, Uncompahgre, and Grand Mesa (GMUG) National Forests (Bankey, 2004). Published maps for the resource assessment are such small-scale that it is not feasible to locate the parcel precisely on them, nor would it be advisable. The parcel is in areas assessed as favorable for granite porphyry and granodiorite porphyry molybdenum deposits (see Silverton caldera tracts, Bove and others, 2004, p. 112, tract 4, and p. 116, tract 9), polymetallic veins (see San Juan Mountains tract, Wilson and others, 2004a, p. 159, tract F5), and polymetallic replacement deposits (see Ouray and San Juan West tracts, Wilson and others, 2004b, p. 172, tract F11).

\section{Federal Lands}

$\underline{\text { Kent expansion }}$

Ouray 1:24,000, Montrose 1:100,000, Montrose 1:250,000 quadrangles.

The sliver of land in this exchange is too small for an accurate resource appraisal. It was difficult to locate the parcel with any certainty on a 1:24,000-scale map to compare with known geology and mineralization. The location shown on Attachment $\mathrm{D}$ is approximate.

The parcel appears to be located in Pleistocene Wisconsin stage glacial drift (Luedke and Burbank, 1962). Pleistocene and Holocene landslide deposits nearly surround the parcel (Attachment D).

The parcel is located in the San Juan mineralized area and immediately outside the Ouray mineralized area (Wilson and others, 2000; Wilson, 2003). The parcel is south of the Ouray mining district (Davis and Streufert, 1990). This area is included in the mineral resource assessment of the Gunnison, Uncompahgre, and Grand Mesa (GMUG) National Forests (Bankey, 2004). Published maps for the resource assessment are such small scale that it is not 
feasible to locate the parcel precisely on them, nor would it be advisable. The parcel is on the margin of the area assessed as favorable for granite porphyry (see Silverton caldera tract, Bove and others, 2004, p. 112, tract 5), polymetallic veins (see San Juan Mountains tract, Wilson and others, 2004a, p. 159, tract F5), and polymetallic replacement deposits (see Ouray and San Juan West tracts, Wilson and others, 2004b, p. 172, tract F11).

\section{LIST OF ATTACHMENTS:}

A. Report Request (provided by U.S. Forest Service).

B. $\quad$ Exhibits A and B (provided by U.S. Forest Service).

C. Portion of geologic map Ironton quadrangle (Burbank and Luedke, 1964) showing approximate location of non-Federal parcels.

D. Portion of geologic map of Ouray quadrangle (Luedke and Burbank, 1962) showing approximate location of Federal parcel and approximate outlines of Ouray and San Juan mineralized areas (from Wilson and others, 2000; Wilson, 2003). 


\section{REFERENCES:}

Bankey, Viki, ed., 2004, Resource potential and geology of the Grand Mesa, Uncompahgre, and Gunnison (GMUG) National Forests and vicinity, Colorado: U.S. Geological Survey Professional Paper 2213.

Bove, D.J., Knepper, D.H., Jr., Bankey, Viki, Spanski, G.T., and Smith, S.M., 2004, Mineral resource assessment for porphyry molybdenum deposits, in Bankey, Viki, ed., Resource potential and geology of the Grand Mesa, Uncompahgre, and Gunnison (GMUG) National Forests and vicinity, Colorado: U.S. Geological Survey Professional Paper 2213, p. 105-123.

Burbank, W.S., and Luedke, R.G., 1964, Geologic map of the Ironton quadrangle, Colorado: U.S. Geological Survey Geologic Quadrangle Map GQ-291, scale 1:24,000.

Davis, M.W., and Streufert, R.K., 1990, Gold occurrences of Colorado: Colorado Geological Survey Resource Series 28, 101 p.

Luedke, R.G., and Burbank, W.S., 1962, Geologic map of the Ouray quadrangle, Colorado: U.S. Geological Survey Geologic Quadrangle Map GQ-152, scale 1:24,000.

Wilson, A.B., 2003, Databases and simplified geology for mineralized areas, claims, mines and prospects in Colorado: U.S. Geological Survey Open-File Report 03-090. [http://pubs.usgs.gov/of/2003/ofr-03-090/]

Wilson, A.B., Nash, J.T., Spanski, G.T., Bankey, Viki, and Smith, S.M., 2004a, Mineral resource assessment for polymetallic vein deposits, in Bankey, Viki, ed., Resource potential and geology of the Grand Mesa, Uncompahgre, and Gunnison (GMUG) National Forests and vicinity, Colorado: U.S. Geological Survey Professional Paper 2213, p. 150-163.

Wilson, A.B., Spanski, G.T., Bankey, Viki, and Smith, S.M., 2004b, Mineral resource assessment for polymetallic replacement deposits, in Bankey, Viki, ed., Resource potential and geology of the Grand Mesa, Uncompahgre, and Gunnison (GMUG) National Forests and vicinity, Colorado: U.S. Geological Survey Professional Paper 2213, p. 164-176.

Wilson, A.B., Spanski, G.T., Crane, M.J., and Woodard, M.D., 2000, Databases and spatial data model for mineralized areas, mines, and prospects in the Grand Mesa, Uncompahgre, and Gunnison (GMUG) National Forests, Colorado: U.S. Geological Survey Open-File Report 00-298. [http://pubs.usgs.gov/of/2000/ofr-00-0298/] 


\section{Attachment A. Report request (provided by U.S. Forest Service).}

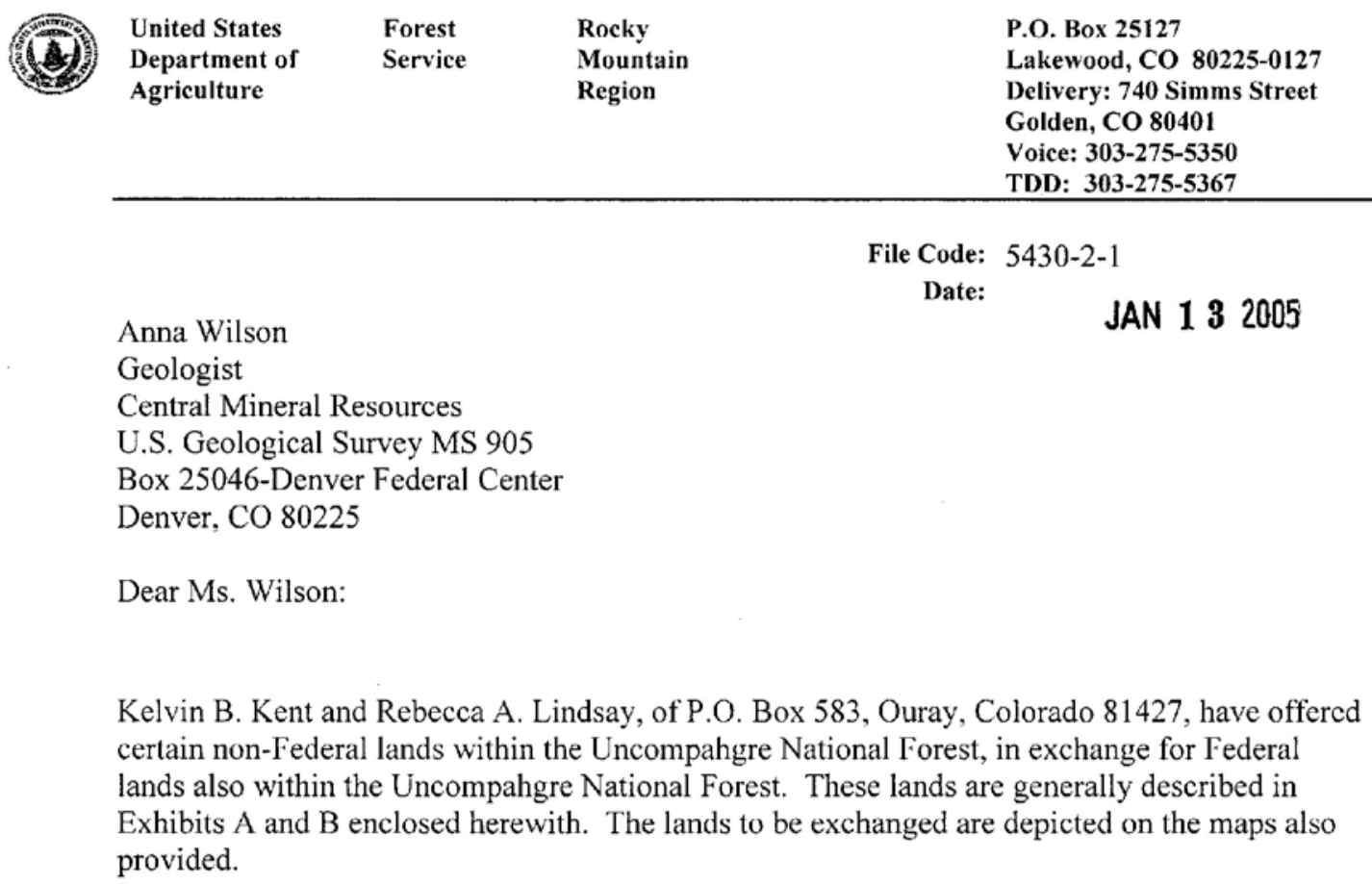

In accordance with the working agreement under Public Law 86-509, please provide a report on the locatable mineral resources on the lands described in Exhibits A and B. Please specify in your report the mineral or minerals involved. Please send your report to the letterhead address.

If you have any questions, you may contact Nancy Hollenkamp at (303) 275-5382.

Sincerely,

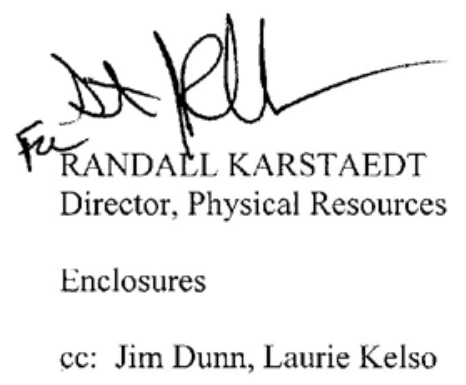




\section{Attachment B. Exhibits A and B (provided by U.S. Forest Service)}

\section{EXHIBIT A}

Property that the Non-Federal Party will consider exchanging:

New Mexico Principal Meridian, Ouray County, Colorado

August Flower, Gold Coin, High Ball, Fillipino, Cracker Jack, Luzon and King Edward Mining Claims, Mineral Survey \#19190, in the Mt. Sneffels Mining District, and embracing portions of Townships 42 and 43 North, Range 8 West,

EXCEPT those portions thereof lying within Gertrude Lode Mining Claim, Survey No. 1548A; Snow Bank Lode Mining Claim, Survey No. 6049, War Eagle Lode Mining Claim, Survey No. 17424; and Juneau No. 2, Dodo and Kootenai Lode Mining Claims, Survey No. 14450.

Containing 59.577 acres, more or less.

\section{EXHIBIT B}

Property that the U.S.D.A. Forest Service will consider exchanging:

\section{New Mexico Principal Meridian, Ouray County, Colorado}

A parcel of Federal land located adjacent to and just south of the existing Kent property, more particularly described at this time as a 1.059 acre parcel adjacent to Lot 3 Campbell Subdivision and Part of Waldrum Exemption No. 2 at Mineral Farms, Ouray, Colorado.

On an FS map the area in not surveyed, but the parcel is located in a protracted diagram.

The Mineral Farms Subdivision is shown as being located in Township 43 North, Range 7 West NMPM, Section 6, SW1/4 SW1/4.

Containing 1.059 acres, more or less.

(NOTE: A survey, under BLM instructions, will need to be completed prior to closing of this transaction.) 
Attachment C. Portion of geologic map Ironton quadrangle (Burbank and Luedke, 1964) showing approximate location of non-Federal parcels. Tsb, Burns Formation of the Silverton Volcanic Group.

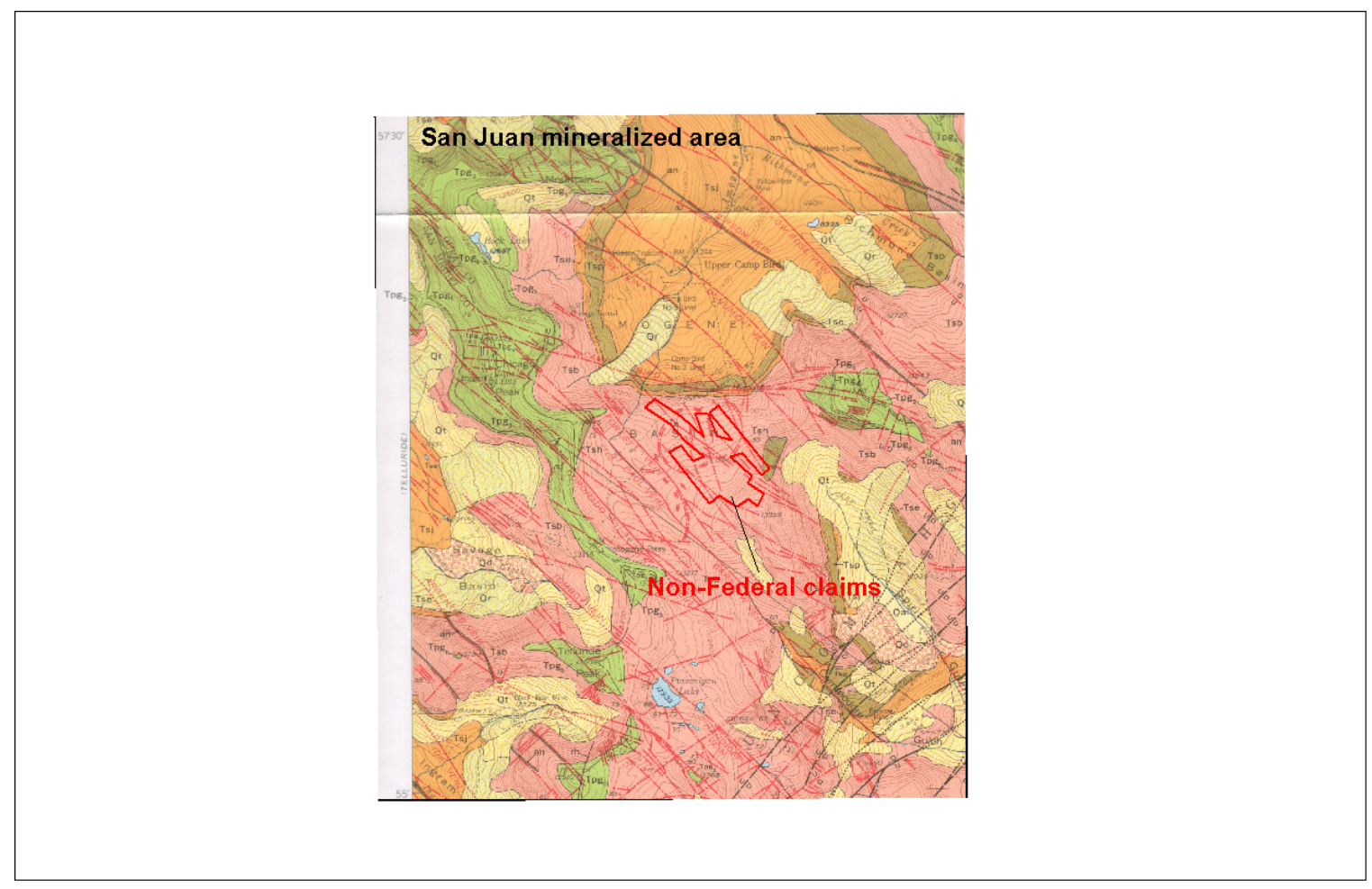


Attachment D. Portion of geologic map of Ouray quadrangle (Luedke and Burbank, 1962) showing approximate location of Federal parcel and approximate outlines of Ouray and San Juan mineralized areas (from Wilson and others, 2000; Wilson, 2003). Qs, Pleistocene and Holocene landslide deposits; Qd, Pleistocene Wisconsin-stage glacial drift; IPh, Pennsylvanian Hermosa Formation.

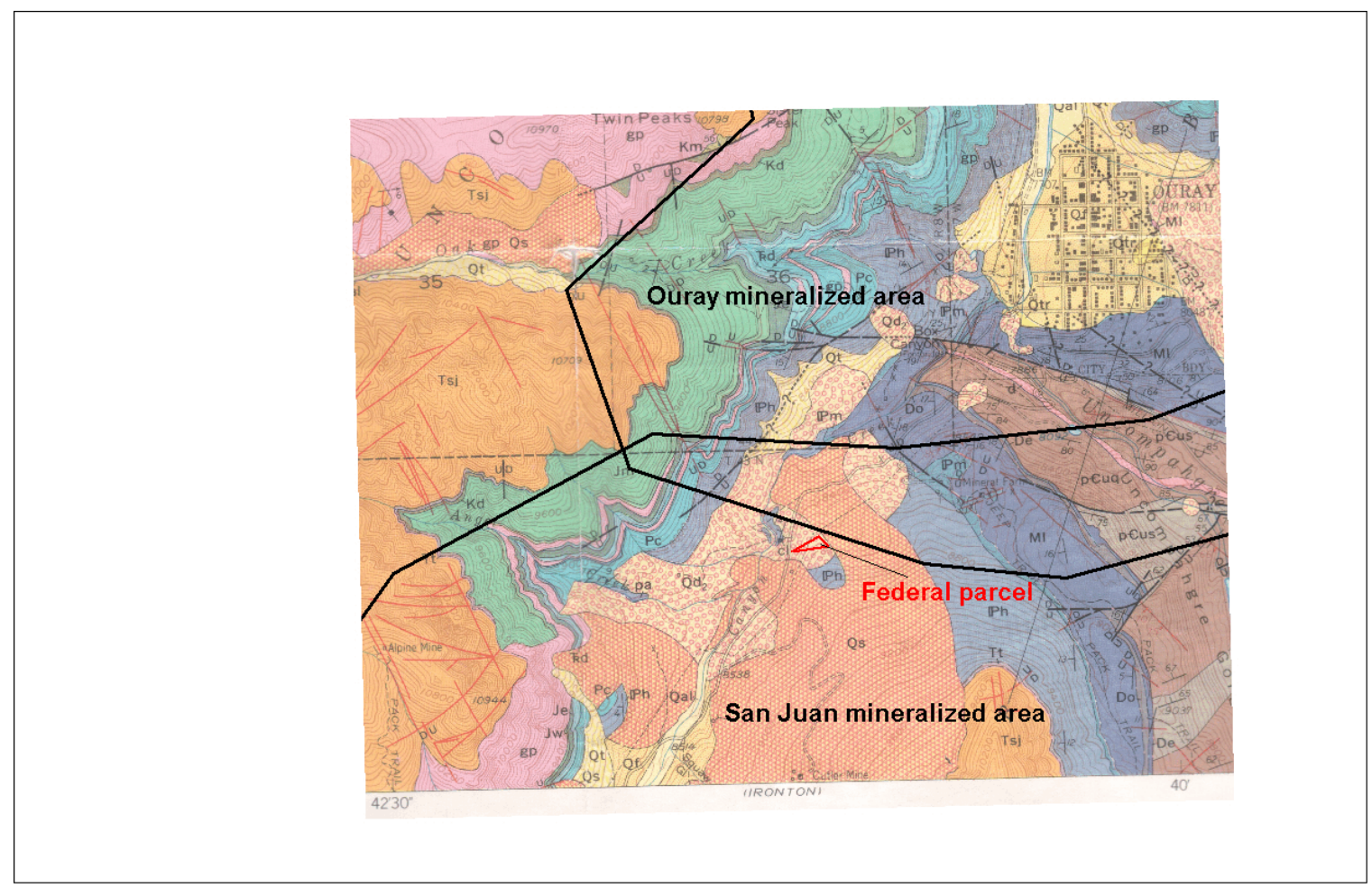




\title{
LOCATABLE MINERAL REPORT FOR THE TELLURIDE AIRPORT LAND EXCHANGE OFFER, UNCOMPAHGRE NATIONAL FOREST, SAN MIGUEL COUNTY, COLORADO
}

\author{
By \\ Anna B. Wilson \\ U.S. Geological Survey \\ Administrative Report \\ August 25, 2005
}

The following report is based on information contained in USGS mineral resource and commodity files, mineral information databases (MRDS and MAS), and on reports and maps available in the USGS library. These data are occasionally augmented with unpublished documents, personal communications, and professional experiences. No field studies or on-site visits were performed in preparing this report. Emphasis is primarily on locatable mineral resources. Leasable and salable resources are covered only if they appear in the above documents. Mineral resource assessments are subjective: the opinions expressed herein are entirely those of the author. This report has not been reviewed for stratigraphic nomenclature. 


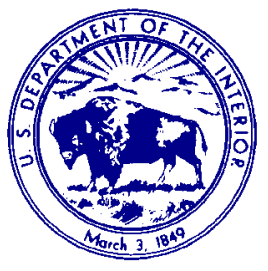

U.S. Department of the Interior

U.S. Geological Survey

Box 25046, MS 964

Denver Federal Center

Denver CO, 80225

(303) 236-5593

awilson@usgs.gov

August 25, 2005

Mr. Randall Karstaedt

Director, Physical Resources

U.S. Forest Service

P.O. Box 25127

Lakewood, CO 80225-0127

Dear Mr. Karstaedt:

This report is in response to your June 28 request for information on locatable mineral resources in a land exchange proposal in which the Telluride Airport Authority has offered certain nonFederal lands within the Uncompahgre National Forest in exchange for Federal lands also within the Uncompahgre National Forest.

In accordance with our long-term working agreement under Public Law 86-509, we are providing you with a report on the locatable mineral resources on the lands described in Exhibits A and B, which were included with your request. These lands comprise approximately 95.7 acres in San Miguel County, Colorado.

Sincerely yours,

Anna B. Wilson, Geologist

Mineral Resources Program, Central Region

Copies:

C.J. Nutt

N. Hollenkamp

J.S. Dersch 
For the legal location description of lands considered for exchange, refer to Exhibits A and B in Attachment A. The report request is Attachment B. Attachments C, D, and E are geologic maps showing the approximate locations of the non-Federal parcels.

\section{Non-Federal Lands}

Parcels 1 "Wynne Property"

Ophir 1:24,000, Silverton 1:100,000, Durango 1:250,000 quadrangles.

The Wynne parcel is immediately west of Ophir Loop. The bedrock geology is mapped as Upper Jurassic Morrison Formation intruded by Oligocene granodiorite (Luedke, 1996; Attachment C).

The parcel is at the margin of the Ophir mineralized area, the historic Iron Springs Mining District. Although not included in the USGS mine and prospect databases (Wilson, 2003; and A.B. Wilson, unpublished data, 2005), the parcel is a patented claim and is near other patented lode claims, some with a history of production. Therefore, mineral resource potential for commodities such as gold, silver, and lead is expected to be high.

Parcel 2 "Greenberg properties"

Ophir 1:24,000, Silverton 1:100,000, Durango 1:250,000 quadrangles.

Most of the Greenberg parcel is mapped as rhyodacite tuff breccia of the Miocene(?) San Juan Formation (Tsj, orange), which is cut by veins and mineralized fissures (red) (Burbank and Luedke, 1966; Attachment D).

The parcel is made up of three patented claims: Little Bessie, Modena, and Gertrude Lodes. At the time the claims were patented, the claim holder had to demonstrate that the claimed lands contained viable and economic mineral deposits. There is no information in the literature citing the mineral commodities expected or produced. Proximity to the Nellie, Wasatch, Roy Johnson, and other mines (Wilson, 2003; and A.B. Wilson, unpublished data, 2005) and the similar geologic setting suggest that the most likely sought commodities-silver, gold, and lead-would have been the same as on those properties: silver, gold, and lead. Therefore, mineral-resource potential for these commodities on the Greenberg properties is high.

\section{Federal Lands}

Telluride Airport Authority

Gray Head 1:24,000, Silverton 1:100,000, Durango 1:250,000 quadrangles.

The Airport parcel is in an area that is underlain by most of the Upper Jurassic and Upper Cretaceous stratigraphic section (Bush and others, 1951; Attachment E). At the lowest elevations in Deep Creek, Upper Jurassic Entrada Sandstone is exposed, overlain successively by Wanaka Formation, the Salt Wash sandstone and Brushy Basin shale members of the Morrison 
Formation, and capped by Upper Cretaceous Dakota Sandstone on the plateau (Bush and others, 1951). The sedimentary rocks are cut by the N68W-trending Vanadium fault which is downthrown on the northeast.

Mineral prospects in Deep Creek are only a few hundred feet north of the parcel. Based on the geologic map (Bush and others, 1961), it is probable that the workings in Deep Creek explored vein or replacement deposits directly associated with the Vanadium fault in the Wanakah Formation. Deep Creek mine (location uncertain) may have been mined for calcium, but no information is available. Unverified information in the MRDS and MAS databases (Wilson, 2003) suggests that the other mines in Deep Creek may be the Blue Bird, Blue Bell, Crescent City, and(or) Lakeview. None of the references attributed to these mines contains specific information about the mine, and no information could be located for any of these "mines" although the databases suggest that silver was the primary commodity, and there may have been some lead. It is unclear if the mines in Deep Creek were productive. It also is possible that this is a case of mistaken identity. The "newMRDS" database (USGS, 2005, unpublished data) describes the location as a placer deposit, but the publication cited (Bush and others, 1959) for the Placerville quadrangle (to the northwest) does not appear to contain information about the deposit. If location information is correct, the potential for small, silver replacement deposits is high. The parcel is several miles east of the known vanadium and chromium belts (Fischer, 1968, fig. A); resource potential for these commodities is low.

\section{LIST OF ATTACHMENTS:}

A. Exhibits A and B. Legal description of land considered in this exchange (provided by USDA Forest Service).

B. Report request (provided by USDA Forest Service).

C. Geologic map showing approximate location of the Wynne property (after Luedke, 1996; A.B. Wilson, unpublished data, 2005).

D. Geologic map showing approximate locations of the Greenberg properties (after Burbank and Luedke, 1966; A.B. Wilson, unpublished data, 2005).

E. Geologic map showing approximate locations of the Airport lands adjacent to the Airport (after Bush and others, 1961; A.B. Wilson, unpublished data, 2005). 


\section{REFERENCES:}

Burbank, W.S., and Luedke, R.G., 1966, Geologic map of the Telluride quadrangle, southwestern Colorado: U.S. Geological Survey Geologic Quadrangle Map GQ-504, scale 1:24,000.

Bush, A.L., Bromfield, C.S., Marsh, O.T., and Taylor, R.B., 1961, Preliminary geologic map of the Gray Head quadrangle, San Miguel County, Colorado: U.S. Geological Survey Mineral Investigations Field Studies Map MF-176, scale 1:24,000.

Bush, A.L., Bromfield, C.S., and Pierson, C.T., 1959, Areal geology of the Placerville quadrangle, San Miguel County, Colorado: U.S. Geological Survey Bulletin 1072-E, p. 295-384, scale 1:24,000.

Fischer, R.P., 1968, Vanadium deposits of the Placerville area, San Miguel County, Colorado, in Shomaker, John, Guidebook of San Juan-San Miguel-La Plata region, New Mexico and Colorado: New Mexico Geological Society $19^{\text {th }}$ Field Conference, p. 100-103.

Luedke, R.G., 1996, Geologic map of the Ophir quadrangle, San Juan, San Miguel, and Dolores Counties, Colorado: U.S. Geological Survey Geologic Quadrangle Map GQ-1760, scale $1: 24,000$.

Wilson, A.B., 2003, Databases and simplified geology for mineralized areas, claims, mines and prospects in Colorado: U.S. Geological Survey Open-File Report 03-090. http://pubs.usgs.gov/of/2003/ofr-03-090/ 
Attachment A. Exhibits A and B: Legal description of land considered in this exchange (provided by U.S.D.A. Forest Service).

\section{EXHIBIT A}

Property that the non-Federal party will consider exchanging:

\section{Parcel 1 Wynne Property:}

$\underline{\text { New Mexico Principal Meridian }}$

\section{T. 42 N., R. 9 W.}

Sections 32 and 33: Parcel 2 of the Roanoak Placer MS\# 15590, less the remediated mine tailings area as depicted on the unapproved plat entitled "Plat of Survey for the Wynne - U.S. Forest Service Land Exchange and the Reserved Right-of-way located in NE1/4, S32, T42N, R9W, N.M.P.M. and NW1/4, S33, T42N, R9W," San Miguel County, Colorado.

Containing $29.32 *$ acres, more or less.

( Note: Parcel will require completion of a Forest Service approved survey prior to closing of this transaction.)

\section{Parcel 2 Greenberg Properties:}

\section{$\underline{\text { New Mexico Principal Meridian }}$}

Modena Lode and Gertrude Lode, Mineral Survey No. 13375; Little Bessie Lode, Mineral Survey No. 5521; EXCEPTING therefrom any ground embraced within Mineral Surveys No. 2402 and 4748, Johnson Lode a/k/a M. Johnson Lode, Mineral Survey No. 18989; all located in the Upper San Miguel Mining District, San Miguel County, Colorado.

Containing 29.34 acres, more or less.

Containing an aggregate of 58.66 acres, more or less, San Miguel County, Colorado.

\section{EXHIBIT B}

Property that the U.S.D.A. Forest Service will consider exchanging:

New Mexico Principal Meridian

\section{T. 43 N., R. $10 \mathrm{~W}$.}

Section 25: a portion of the SW1/4.

Containing approximately $37^{*}$ acres, more or less, San Miguel County, Colorado.

(*Note: Parcel will require completion of a BLM cadastral survey prior to closing of this transaction.) 


\section{Attachment B. Report Request (provided by U.S.D.A. Forest Service).}

$\begin{array}{lll}\text { United States } & \text { Forest } & \text { Rocky } \\ \text { Department of } & \text { Service } & \text { Mountain } \\ \text { Agriculture } & & \text { Region }\end{array}$
Agriculture
Region
P.O. Box 25127

Lakewood, CO 80225-0127 Delivery: 740 Simms Street Golden, CO 80401

Voice: 303-275-5350

TDD: $303-275-5367$

File Code: 5430

Date:

JUN 282005

Anna Wilson, Geologist

U.S. Geological Survey

Central Mineral Resources MS 905

Box 25046, Denver Federal Center

Denver, CO 80225

Dear Ms. Wilson:

The Telluride Regional Airport Authority of 1500 Last Dollar Road, Suite 1, Telluride, Colorado 81435 has offered certain non-Federal lands within the Uncompahgre National Forest in exchange for Federal lands also within the Uncompahgre National Forest. These lands are generally described in Exhibits A and B enclosed herewith. The lands to be exchanged are also depicted on the enclosed maps.

In accordance with the working agreement under Public Law 86-509, please provide a report on the locatable mineral resources on the lands described in Exhibits A and B. Please specify in your report the mineral or minerals involved. Please send your report to the letterhead address.

If you have any questions, please contact Nancy Hollenkamp at 303-275-5382.

Sincerely,

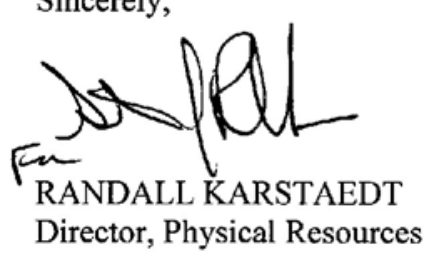

Enclosures

cc: Dee A Closson, Jim Dunn 


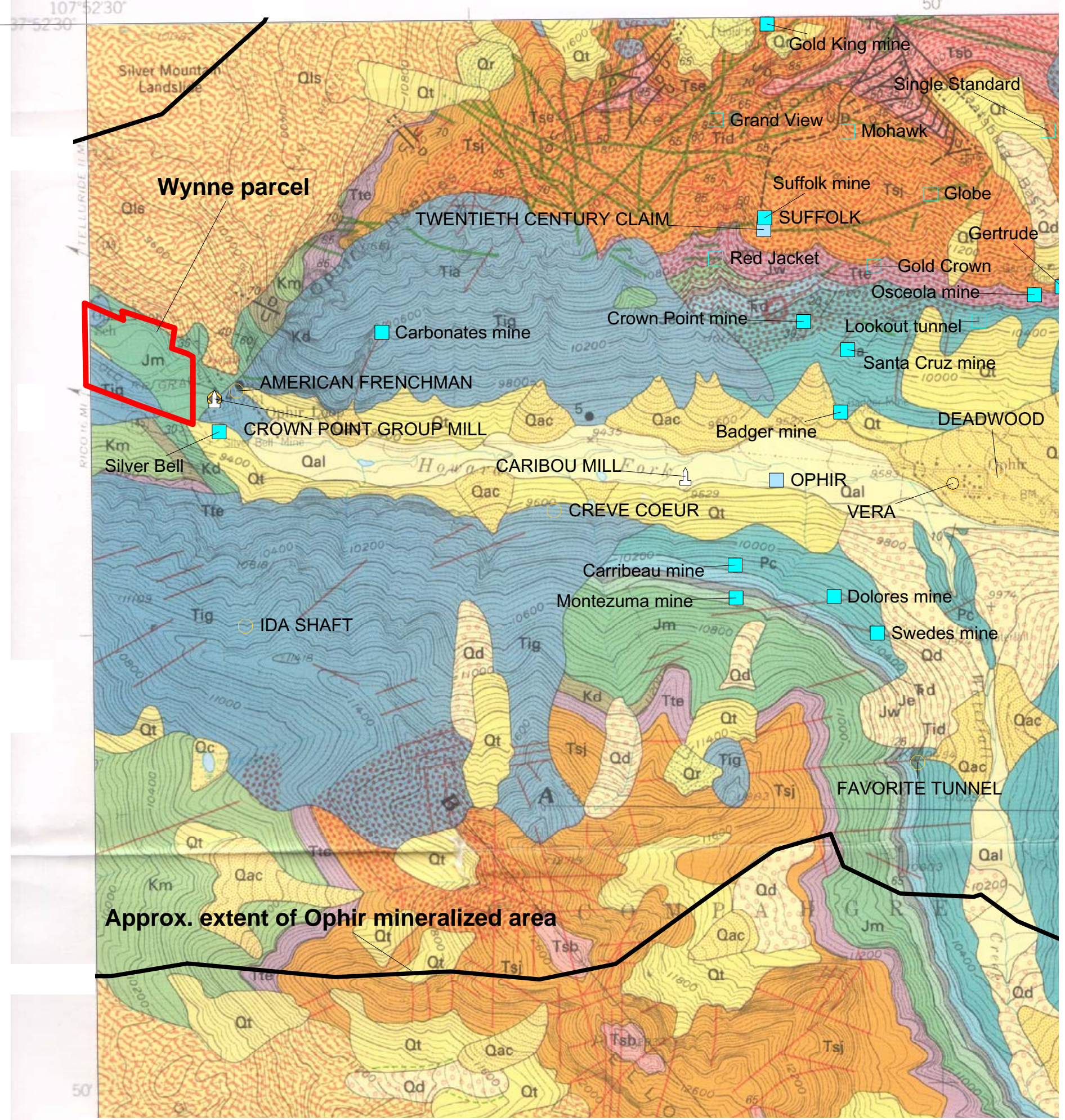




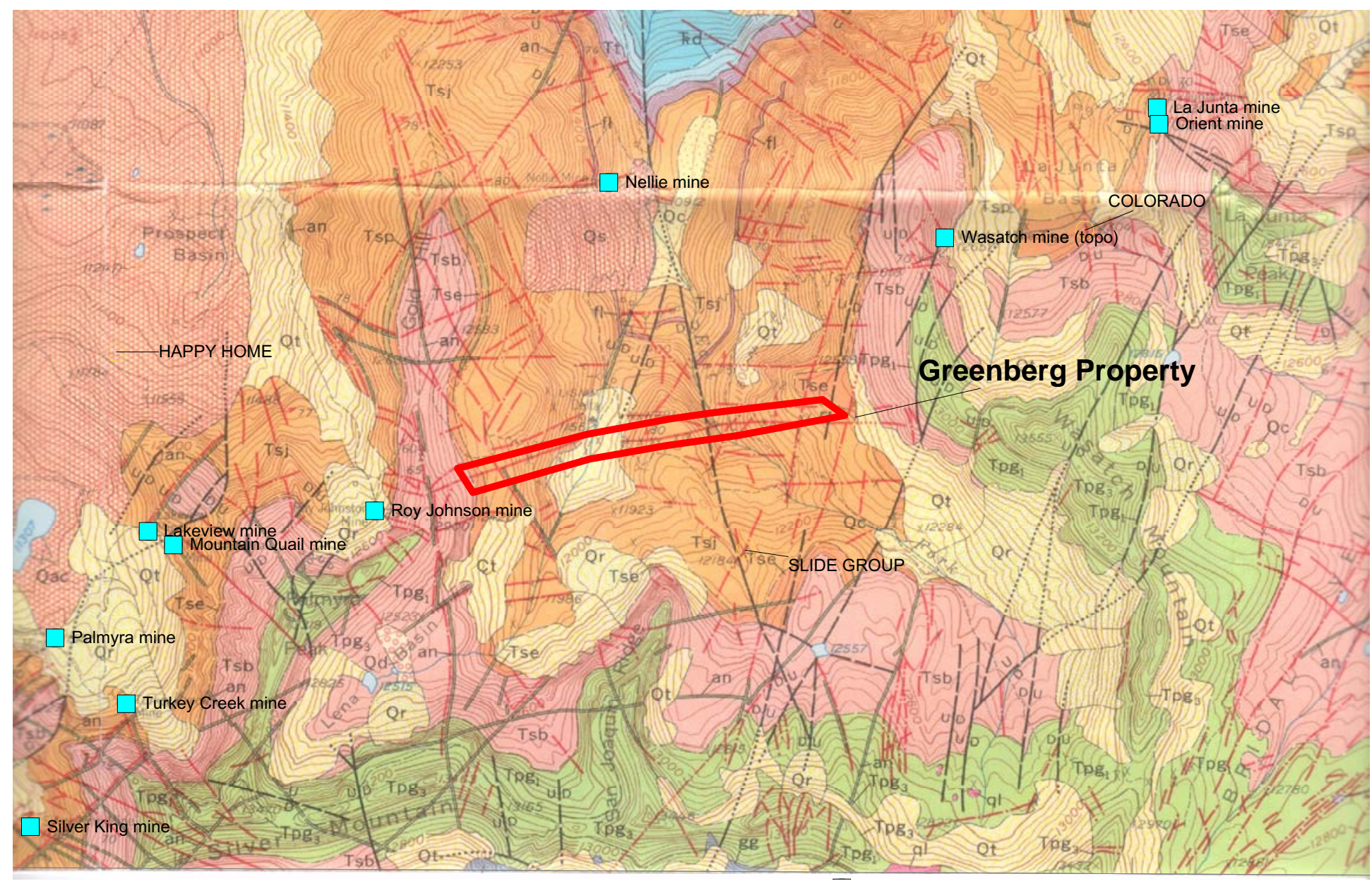




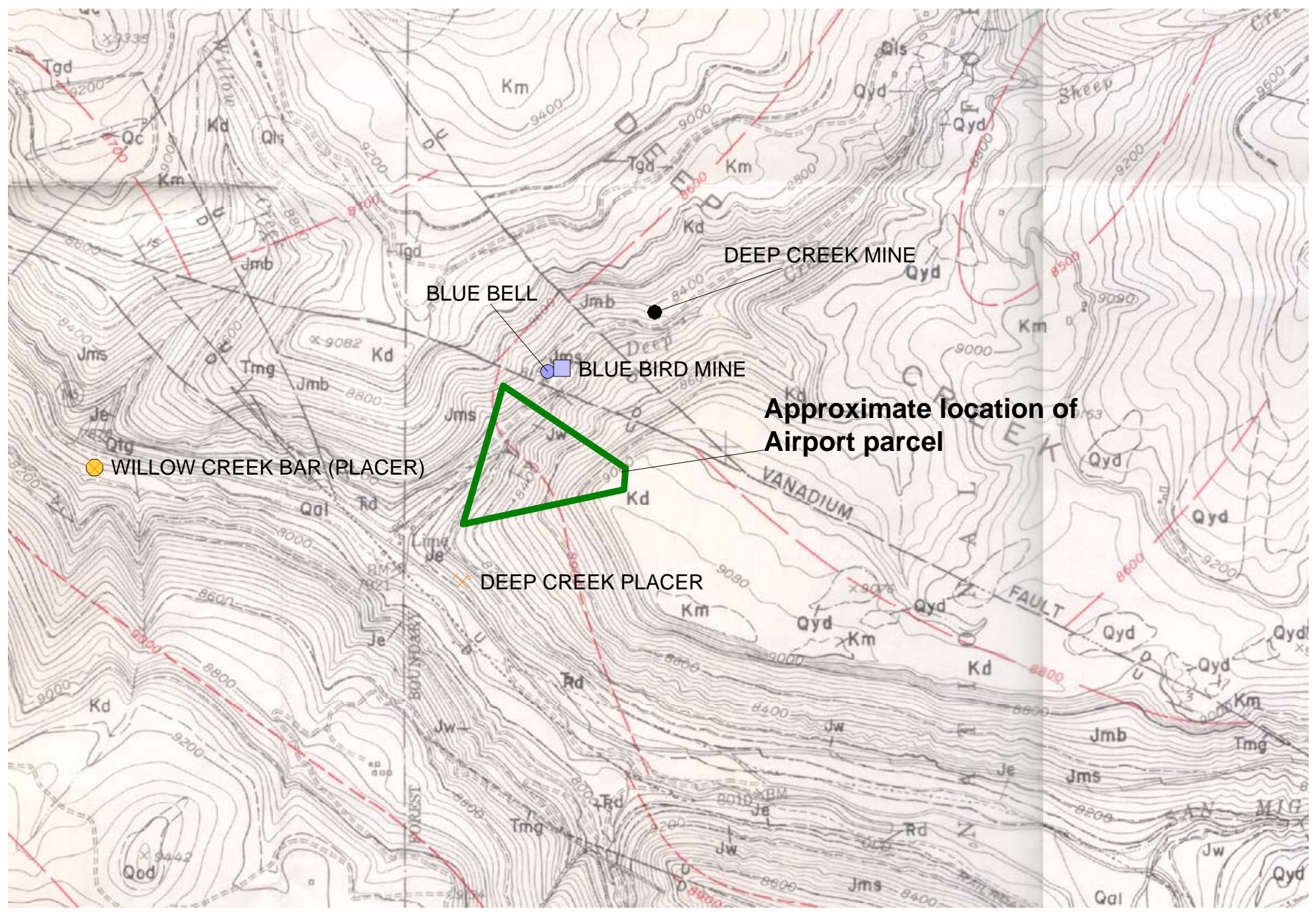




\title{
LOCATABLE MINERAL REPORT FOR THE SOUTH GAME CREEK (VAIL CORPORATION) EXCHANGE, WHITE RIVER NATIONAL FOREST, EAGLE COUNTY, COLORADO
}

\author{
By \\ Anna B. Wilson \\ U.S. Geological Survey \\ Administrative Report
}

December 1, 2004

The following report is based on information contained in USGS mineral resource and commodity files, mineral information databases (MRDS and MAS), and on reports and maps available in the USGS library. These data are occasionally augmented with unpublished documents, personal communications, and professional experiences. No field studies or on-site visits were performed in preparing this report. Emphasis is primarily on locatable mineral resources. Leasable and salable resources are covered only if they appear in the above documents. Mineral resource assessments are subjective: the opinions expressed herein are entirely those of the author. 


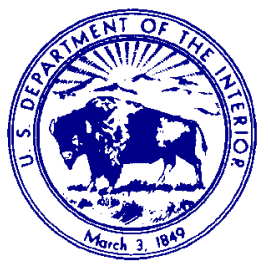

U.S. Department of the Interior

U.S. Geological Survey

Box 25046, MS 964

Denver Federal Center

Denver CO, 80225

(303) 236-5593

FAX (303) 236-3200

awilson@usgs.gov

January 14, 2005

Mr. Randall Karstaedt

Director, Physical Resources

U.S. Forest Service

PO Box 25127

Lakewood, CO 80225-0127

Dear Mr. Karstaedt:

This report is in response to your November 4 request for information on locatable mineral resources in a land exchange proposal in which the Vail Corporation has offered certain nonFederal lands within the White River National Forest in exchange for Federal lands, also within the White River National Forest.

In accordance with our long-term working agreement under Public Law 86-509, we are providing you with a report on the locatable mineral resources on the lands described in Exhibits $\mathrm{A}$ and $\mathrm{B}$, which were included with your request. These lands comprise approximately 615 acres in Eagle County, Colorado.

Sincerely yours,

Anna B. Wilson, Geologist

Mineral Resources Program, Central Region

Copies: $\quad$ C.J. Nutt

N. Hollenkamp

J.S. Dersch 
The report request is Attachment A (provided by the U.S. Forest Service). Refer to Attachment $\mathrm{B}$ for the location description of lands considered for exchange. (For simplicity, land reservations, outstanding rights, and other exclusions listed in Exhibits A and B provided by the U.S. Forest Service are not included in Attachment B.) Attachment C is a simplified geologic map showing the approximate locations of the Federal and non-Federal parcels.

\section{$\underline{\text { Non-Federal Lands }}$}

Parcel A: South Game Creek Bowl

Minturn 1:24,000, Leadville 1:100,000, Leadville 1:250,000 quadrangles.

The South Game Creek parcel is located in Game Creek. The bedrock geology is Middle Pennyslvanian Minturn Formation overlain by unconsolidated Holocene and Pleistocene landslide deposits and thick colluvium (Tweto and others, 1978; Day and others, 1999). Minturn Formation is composed of "grit, conglomerate, sandstone, shale, and intercalated beds of carbonate rocks" (Tweto and Lovering, 1977).

There are no known mines, prospects or mining districts in these host rocks in the vicinity of the parcel (Wilson, 2003). The closest mining district, Gilman-Redcliff, is 3 to 7 miles to the south. In the resource assessment of the White River National Forest, Toth and others (1993) did not assign any potential for locatable mineral resources to the area surrounding this parcel. Therefore, mineral resource potential for locatable minerals in the Game Creek parcel is considered to be low.

Parcel B: Vassar Meadows

Fulford 1:24,000, Vail 1:100,000, Leadville 1:250, 000 quadrangles.

Geologically, the Vassar Meadows parcel is mapped as Pleistocene (Bull Lake and younger) unconsolidated glacial drift overlying Lower Triassic and Permian State Bridge Formation (Attachment C) lying within the southeastern end of the downthrown, fault-bounded Hardscrabble Mountain block (Tweto and others, 1978). The lower elevations of the parcel are riparian wetlands in Quaternary alluvium. The sides of the valley are underlain by State Bridge Formation, overlain by varying thicknesses of colluvium. Additional geologic mapping and studies that could be consulted include Hubert (1954), Gableman (1949, 1950), Lueck (1970), and Richards (1982).

Parcel B lies 2 to 3 miles west of the Polar Star and Johnson mines and the Fulford and Brush Creek mining areas (Gableman, 1949, 1950; Lueck, 1970; Richards, 1982; Brown, 1990; Wilson, 2003). The area labeled "Fulford District" on Attachment C includes the Brush Creek district in the north and the Fulford district in the south (Vanderwilt, 1947, p. 77-78). (According to Vanderwilt, Brush Creek district, active from 1912 to 1926, contained silver veins in Dakota Sandstone. Mineralization in the Fulford district was said to be similar to Brush Creek, although it is described as lead-silver in Paleozoic dolomite beds.) No mineral resource potential was assigned to the Vassar Meadows area by Toth and others (1993). Therefore, mineral resource potential for locatable minerals in Vassar Meadows is considered to be low. 


\section{Federal Lands}

Parcel 1: Front Door

Empire 1:24,000, Denver West 1:100,000, Denver 1:250,000 quadrangles.

Parcel 1, the Front Door, is an approximately 5 acre parcel located at the base of the Vail ski area adjacent to high-density resort development. At the detailed scale of the provided parcel map compared with the much smaller scale $(1: 48,000)$ geologic map, it is not possible to provide a detailed geologic summary. When geologic mapping of this area was conducted (1940-41, 1946, 1961), the ski area did not exist. The area was mapped as Middle Pennsylvanian Minturn Formation, which is composed of grit, conglomerate, sandstone, and shale, with intercalated beds of carbonate rocks (Tweto and Lovering, 1977). Several carbonate beds in the Robinson Limestone Member may be in or adjacent to the Front Door parcel. The Minturn Formation is mostly gray, but it may be red in the upper part and in an irregular zone near the base. The parcel appears to be on the east flank of the Vail syncline.

There are no known mines, prospects, or locatable mineral occurrences in the vicinity. Toth and others (1993) assessed this area as having no mineral resource potential. Therefore, mineral resource potential for locatable minerals in Vassar Meadows is considered to be low.

\section{LIST OF ATTACHMENTS:}

A. $\quad$ Report request (provided by U.S. Forest Service).

B. Exhibits A and B. Location description exclusive of land reservations, outstanding rights, and other exclusions (provided by U.S. Forest Service).

C. Simplified geologic map showing locations of the parcels (modified from Tweto and Lovering, 1977; Tweto and others, 1978; Day and others, 1999; Wilson, 2003).

\section{REFERENCES:}

Brown, S.D., 1990, Mineral appraisal of the White River National Forest, Colorado: U.S. Bureau of Mines MLA 9-90, 380 p.

Day, W.C., Green, G.N., Knepper, D.H., Jr., and Phillips, R.C., 1999, Spatial geologic data model for the Gunnison, Grand Mesa, Uncompahgre National Forests mineral resource assessment area, southwestern Colorado and digital data for the Leadville, Montrose, Durango, and the Colorado parts of the Grand Junction, Moab, and Cortez $1^{\circ} \mathrm{X} 2^{\circ}$ geologic maps: U.S. Geological Survey Open-File Report 99-427. http://pubs.usgs.gov/of/1999/ofr-99-0427/arc_quad/leadvlle/

Gabelman, J.W., 1949, Geology and ore deposits of the Fulford mining district, Eagle County, Colorado with reconnaissance of the Brush Creek mining district: Golden, Colo., Colorado School of Mines Ph.D. dissertation, 188 p. 
Gabelman, J.W., 1950, Geology of the Fulford and Brush Creek mining districts, Eagle County, Colorado: Colorado Mining Association, Minerals Yearbook, p. 50-52.

Hubert, J.F., 1954, Structure and stratigraphy of an area east of Brush Creek, Eagle County, Colorado: Boulder, University of Colorado M.S. thesis, 104 p.

Lueck, E.W., 1970, The geology of the Fulford mining district (Cenozoic), Eagle County, Colorado: Iowa City, University of Iowa M.S. thesis, 78 p.

Richards, B.D., 1982, Geology of the Mississippian Leadville Limestone; Fulford area, Eagle County, Colorado: Geological Society of America Abstracts with Programs, v. 14, no. 3, $135 \mathrm{p}$.

Toth, M.I., Wilson, A.B., Cookro, T.M., Bankey, Viki, Lee, G.K., and Case, J.E., 1993, Mineral resource potential and geology of the White River National Forest and the Dillon Ranger District of the Arapaho National Forest, Colorado, with a section on Salable commodities, by J.S. Dersch: U.S. Geological Survey Bulletin 2035, 117 p.

Tweto, Ogden, and Lovering, T.S., 1977, Geology of the Minturn 15-minute quadrangle, Eagle and Summit Counties, Colorado: U.S. Geological Survey Professional Paper 956, 96 p., 1 pl., scale 1:48,000.

Tweto, Ogden, Moench, R.H., and Reed, J.C., Jr., 1978, Geologic map of the Leadville $1^{\circ}$ X $2^{\circ}$ quadrangle, northwestern Colorado: U.S. Geological Survey Miscellaneous Investigations Series Map I-999, scale 1:250,000.

Vanderwilt, J.W., 1947, Mineral Resources of Colorado: State of Colorado Mineral Resources Board, p. 77-78.

Wilson, A.B., 2003, Databases and simplified geology for mineralized areas, claims, mines and prospects in Colorado: U.S. Geological Survey Open-File Report 03-090. 


\section{Attachment A. Report request (provided by U.S. Forest Service)}

$\begin{array}{lll}\begin{array}{l}\text { United States } \\ \text { Department of }\end{array} & \text { Forest } & \text { Rocky } \\ \text { Agriculture } & \text { Service } & \begin{array}{l}\text { Mountain } \\ \text { Region }\end{array}\end{array}$

P.O. Box 25127

Lakewood, CO 80225-0127

Delivery: $\mathbf{7 4 0}$ Simms Street

Golden, CO 80401

Voice: 303-275-5350

TDD: 303-275-5367

File Code: 5430-2-1

Date:

\begin{abstract}
Anna Wilson
Geologist

Central Mineral Resources

U.S. Geological Survey MS 905

Box 25046, Denver Federal Center

Denver, CO 80225
\end{abstract}

Dear Ms. Wilson:

The Vail Corporation, a Colorado corporation, of P.O. Box 7, Vail, Colorado 81658, has offered certain non-Federal lands within the White River National Forest, in exchange for Federal lands also within the White River National Forest. These lands are generally described in Exhibits A and $\mathrm{B}$ provided herewith. The lands to be exchanged are depicted on the maps also provided.

In accordance with the working agreement under Public Law 86-509, please provide a report on the locatable mineral resources on the lands described in Exhibits A and B. Please specify in your report the mineral or minerals involved. Please send your report to the letterhead address.

If you have any questions, you may contact Nancy Hollenkamp at (303) 275-5382.

Sincerely,

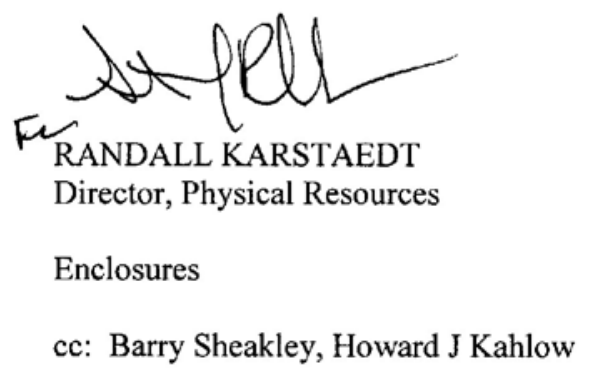




\section{Attachment B. Exhibits A and B. Location description exclusive of land reservations, outstanding rights, and other exclusions (provided by U.S. Forest Service).}

\section{EXHIBIT A}

Property that the Non-Federal Party will consider exchanging:

\section{Non-Federal Parcel A: South Game Creek Bowl}

The SE1/4NE1/4 and the N1/2SE1/4 of Section 24, Township 5 South, Range 81 West of the Sixth Principal Meridian Eagle County, State of Colorado.

Containing 135.511 acres, more or less.

\section{Non-Federal Parcel B: Vassar Meadows}

The W1/2NE1/4, SW1/4SE1/4NE1/4, E1/2NW1/4, SE1/4NW1/4NW1/4, SW1/4NW1/4, $\mathrm{N} 1 / 2 \mathrm{SW} 1 / 4, \mathrm{~N} 1 / 2 \mathrm{~S} 1 / 2 \mathrm{SW} 1 / 4, \mathrm{NW} 1 / 4 \mathrm{SE} 1 / 4, \mathrm{~N} 1 / 2 \mathrm{SW} 1 / 4 \mathrm{SE} 1 / 4, \mathrm{E} 1 / 2 \mathrm{SE} 1 / 4 \mathrm{SW} 1 / 4 \mathrm{SE} 1 / 4$, SE1/4SE1/4, S1/2NE1/4SE1/4 and NW1/4NE1/4SE1/4 of Section 22, Township 6 South, Range 83 West of the Sixth Principal Meridian, Eagle County, State of Colorado.

Containing 475 acres, more or less.

\section{EXHIBIT B}

Property that the U.S.D.A. Forest Service will consider exchanging:

\section{Federal Parcel 1: Front Door:}

A parcel of land situate in the Southwest $1 / 4$ Northwest $1 / 4$ of Section 8 , Township 5 South, Range 80 West of the $6^{\text {th }}$ Principal Meridian, Eagle County, State of Colorado being all of Lot 1 and a portion of Lot 3 to be surveyed and designated as a Lot or Lots, all in said Section 8. Containing approximately 5.0 acres, more of less (to be determined.) 
Attachment C. Simplified geologic map showing location of the parcels (modified from Tweto and Lovering, 1977; Tweto and others, 1978; Day and others, 1999; Wilson, 2003). Qa, Holocene and Pleistocene alluvium; Q1, Holocene and Pleistocene landslide and colluvuim; Qd, Pleistocene glacial drift; TKi, Larmide intrusive rocks; TRPs, Lower Triassic and Permian State Bridge Formation; Pm, Middle Pennsylvanian Minturn Formation. Circles and squares are locations of mines or prospects from the MAS and MRDS databases (Wilson, 2003), respectively. Due to overprinting of multiple entries in the same locations, the color of these points is meaningless. (For more detailed information, see the original maps.) Approximate scale, 1 mile

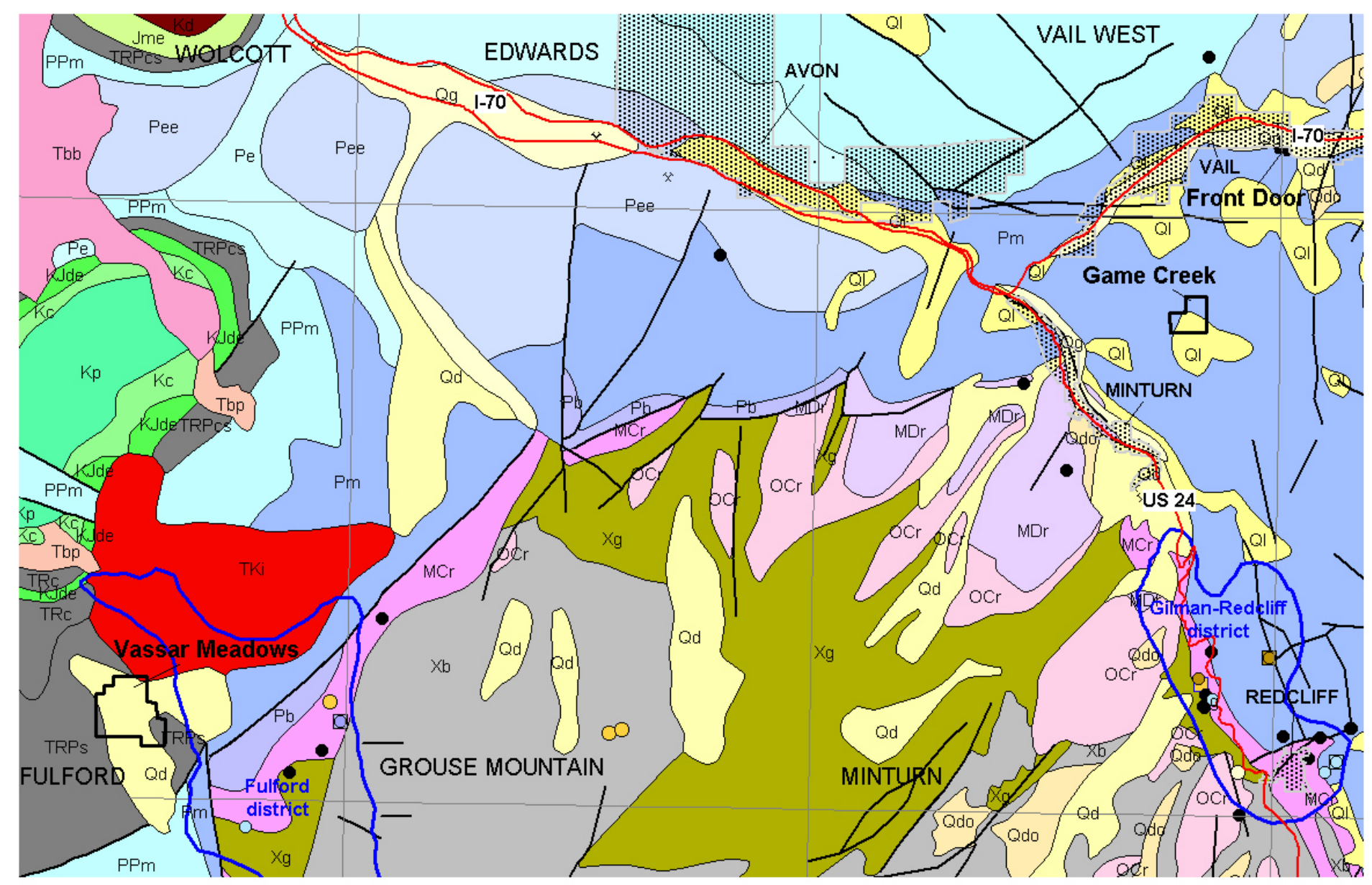


SOUTH DAKOTA 


\section{LOCATABLE MINERAL REPORT FOR THE CATTAIL LAND EXCHANGE OFFER, BLACK HILLS NATIONAL FOREST, CUSTER AND FALL RIVER COUNTIES, SOUTH DAKOTA}

By

Anna B. Wilson

U.S. Geological Survey

Administrative Report

March 8, 2005

The following report is based on information contained in USGS mineral resource and commodity files, mineral information databases (MRDS and MAS), and on reports and maps available in the USGS library. These data are occasionally augmented with unpublished documents, personal communications, and professional experiences. No field studies or on-site visits were performed in preparing this report. Emphasis is primarily on locatable mineral resources. Leasable and salable resources are covered only if they appear in the above documents. Mineral resource assessments are subjective: the opinions expressed herein are entirely those of the author. 


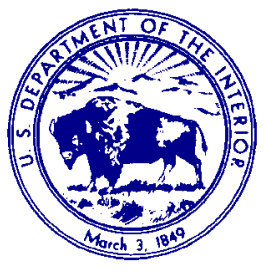

\section{U.S. Department of the Interior}

\section{U.S. Geological Survey}

Box 25046, MS 964

Denver Federal Center

Denver CO, 80225

(303) 236-5593

FAX (303) 236-3200

awilson@usgs.gov

April 1, 2005

Mr. Randall Karstaedt

Director, Physical Resources

U.S.D.A. Forest Service

P.O. Box 25127

Lakewood, CO 80225-0127

Dear Mr. Karstaedt:

This report is in response to your February 9 request (received February 15) for information on locatable mineral resources in the Cattail land exchange proposal in which The Nature Conservancy and Oonagh Wood and Leonard Wood have offered certain non-Federal lands within the Black Hills National Forest in exchange for Federal lands also within the Black Hills National Forest.

In accordance with our long-term working agreement under Public Law 86-509, we are providing you with a report on the locatable mineral resources on the lands described in Exhibits $\mathrm{A}$ and $\mathrm{B}$, which were included with your request. These lands comprise approximately $1,342.04$ acres in Custer and Fall River Counties, South Dakota.

Sincerely yours,

Anna B. Wilson, Geologist

Mineral Resources Program, Central Region

Copies: $\quad$ C.J. Nutt

N. Hollenkamp

J.S. Dersch 
For the legal location description of lands considered for exchange, refer to Exhibits A and B in Attachments A and B. The report request is Attachment C. Simplified geologic maps for the properties are in Attachments D, E, and F.

\section{$\underline{\text { Non-Federal Lands }}$}

TNC property-Lithograph North and Lithograph South

Jewel Cave 1:24,000, Tinton 1:62,500, Sundance 1:100,000, Gillette 1:250,000 quadrangles.

The area is mapped as Lower Permian and Pennsylvanian Minnelusa Formation (PIPm, Attachment D) (Darton and Page, 1925; DeWitt and others, 1989; Martin and others, 2004). It is a light-brown to red and gray sandstone, solution breccia (anhydrite in subsurface), limestone, and shale. The TNC property appears to be located near the lower part of the formation, where there may be weak uranium anomalies.

The TNC property is in an area without potential for locatable commodities (DeWitt and others, 1986) and is not within known metallic mineral areas (Wilson and DeWitt, 1995). Therefore, locatable mineral resource potential on this parcel is very low. The property is in an area assigned low potential (with a low degree of certainty) for small- to medium-sized stratabound oil and gas deposits (DeWitt and others, 1986).

Wood property-Bogli Ranch

Minnekahta NE 1:24,000, Hot Springs 1:100,000, Hot Springs 1:250,000 quadrangles.

Bogli Ranch property is mapped as Lower Permian and Pennsylvanian Minnelusa Formation (PIPm, Attachment E; Martin and others, 2004). The Permian (upper) part of the unit is mostly "brecciated red and yellow sandstone and yellow to gray thin-bedded limestone." The base of the unit is "a prominent mudstone called the 'red marker'." The Pennsylvanian section is "slightly brecciated yellowish-gray dolomite and yellow calcareous sandstone," locally containing thin carbonaceous shale (Wolcott and others, 1962).

Bogli Ranch is in an area without potential for locatable commodities (DeWitt and others, 1986) and is south of known metallic mineral areas (Wilson and DeWitt, 1995). Therefore, locatable mineral resource potential on this parcel is very low. The property is in an area assigned low potential (with a low degree of certainty) for small- to medium-sized stratabound oil and gas deposits (DeWitt and others, 1986). 


\section{Federal Lands}

\section{Buck Canyon property}

Cascade Springs 1:24,000, Fall River 1:100,000, Hot Springs 1:250,000 quadrangles.

Buck Canyon parcel is on the northeast side of Falls Canyon in the Jurassic to Lower Cretaceous Inyan Kara Group rocks (Post, 1967; Martin and others, 2004). The oldest rocks exposed in the canyon are the uppermost member of the Upper Jurassic Sundance Formation, the Redwater Shale Member. This is overlain stratigraphically and topographically by Unkpapa Sandstone. These units are shown on the detailed 1:24,000-scale map (Post, 1967) but not on the simplified State-scale geologic map (Martin and others, 2004; Attachment F). Overlying the Unkpapa is a thin band of mudstone overlain by cliff-forming, fine grained channel sandstone of the Lower Cretaceous Chilson Member of the Lakota Formation (Post, 1967). Variegated mudstone and minor sandstone of the Fuson Member of the Lakota Formation may overlie the Chilson (Post, 1967) at the extreme eastern margin of the property. Lakota Formation (and its members), is the lower part of the Inyan Kara Group, unit Kfl on Attachment F.

Buck Canyon parcel is in an area with high potential for medium-sized roll-front deposits containing uranium and vanadium (DeWitt and others, 1986). The property is in an area assigned low potential for small bedded sedimentary coal deposits (DeWitt and others, 1986). At the scale of the assessment, it is possible that the parcel is at the margin of an area assessed with moderate potential for medium-sized stratabound oil and gas deposits (DeWitt and others, 1986).

\section{Green Canyon property}

Angostura Reservoir 1:24,000, Fall River 1:100,000, Hot Springs 1:250,000 quadrangles.

Green Canyon parcel is on the east flank of the Cascade anticline, in Lower Cretaceous middle and upper parts of the Fall River Formation. Fall River Formation, the upper part of the Inyan Kara Group (unit Kfl, Attachment F), consists of interbedded sandstone and mudstone. The parcel may be overlain by poorly sorted sand and gravel Quaternary terrace deposits (unit Qt, Attachment F) (Connor, 1963).

Green Canyon parcel is in an area with moderate potential for small- to medium-sized roll-front deposits containing uranium and vanadium (DeWitt and others, 1986). However, there are no known deposits on the east flank of the Cascade anticline. The property is in an area assigned low potential (with a low degree of certainty) for small- to medium-sized stratabound oil and gas deposits (DeWitt and others, 1986). 


\section{Cattail property}

Cascade Springs 1:24,000, Fall River 1:100,000, Hot Springs 1:250,000 quadrangles.

The Cattail parcel is between Falls and Lindsley Canyons in Lower Cretaceous Lakota and Fall River Formations of the Inyan Kara Group rocks (Post, 1967; Martin and others, 2004, unit Kfl). The oldest rocks exposed are cliff-forming channel sandstones of the Chilson Member of the Lakota Formation overlain by variegated mudstone and minor sandstone of the Fuson Member. The lowest unit of the Fall River Formation is a siltstone. In the parcel, it is overlain by a cliffforming sandstone in the middle unit of the Fall River Formation topped by red to variegated mudstone and sandstone of the upper unit (Post, 1967).

Buck Canyon parcel is in an area with high potential for medium-sized roll-front deposits containing uranium and vanadium (DeWitt and others, 1986). The property is in an area assigned low potential for small bedded sedimentary coal deposits and moderate potential for medium-sized stratabound oil and gas deposits (DeWitt and others, 1986).

\section{Ruby Creek property}

Berne 1:24,000, Mount Rushmore 1:100,000, Hot Springs 1:250,000 quadrangles.

Proterozoic quartz-biotite-garnet schist (unit Xbs, Attachment D) underlies most of the Ruby Creek property which is near the axis of the Park Dome (Redden, 1968). There may be small, layered pegmatite bodies on the property.

Ruby Creek property is less than $0.5 \mathrm{~km}$ west of the Ballard, Crown, and Rachel D. mines (DeWitt and others, 1988). The first two mines are pegmatites with large amounts of mica, the last is a deposit rich in feldspar. These deposits formed about 1.6 to $1.8 \mathrm{Ga}$ (billion years ago). Immediately west of the property is the Custer Park No. 2 Placer. The area is in the Park mineralized area which contains deposits of potassium feldspar and mica (Wilson and DeWitt, 1995). The parcel is in an area assigned high potential for small- to medium-sized deposits of pegmatite commodities (such as feldspar, mica, lithium, beryllium, tantalum, and tungsten) with the exception of tin (DeWitt and others, 1986). 
Argyle property

Pringle 1:24,000, Mount Rushmore 1:100,000, and Hot Springs 1:250,000 quadrangles.

Lower Permian and Pennsylvanian Minnelusa Formation (unit PIPm, Attachment E) underlies the Argyle property (Darton and Paige, 1925; DeWitt and others, 1989). It is a light-brown to red and gray sandstone, solution breccia (anhydrite in subsurface), limestone, and shale.

The Argyle property is in an area without potential for locatable commodities (DeWitt and others, 1986) and is outside the areas identified as metallic mineral areas (Wilson and DeWitt, 1995). Therefore, locatable mineral resource potential on this parcel is very low. The property is in an area assigned low potential (with a low degree of certainty) for small- to medium-sized stratabound oil and gas deposits (DeWitt and others, 1986).

\section{LIST OF ATTACHMENTS:}

A. Exhibit A. Legal description of non-Federal land considered in this exchange (provided by U.S. Forest Service).

B. Exhibit B. Legal description of Federal land considered in this exchange (provided by U.S. Forest Service).

C. Report request (provided by U.S.D.A. Forest Service).

D. Simplified geologic map (after Martin and others, 2004) showing approximate location of TNC (Lithograph) and Ruby Creek Properties in the Jewel Cave and Berne quadrangles.

E. Simplified geologic map (after Martin and others, 2004) showing approximate location of Wood (Bogli Ranch) and Argyle Properties in the Minnekahta NE and Pringle quadrangles.

F. Simplified geologic map (after Martin and others, 2004) showing approximate location of Black Canyon, Cattail, and Green Canyon Properties in the Cascade Springs and Angostura Reservoir quadrangles. 


\section{REFERENCES:}

Connor, J.J., 1963, Geology of the Angostura Reservoir quadrangle, Fall River County, South Dakota: U.S. Geological Survey Bulletin 1063-D, p. 85-126, scale 1:24,000.

Darton, N.H., and Paige, Sidney, 1925, Central Black Hills [quadrangle], South Dakota: U.S. Geological Survey Geologic Atlas of the United States, Folio 219, scale 1:125,000.

DeWitt, Ed, Redden, J.A., Buscher, David, and Wilson, A.B., 1989, Geologic map of the Black Hills area, South Dakota and Wyoming: U.S. Geological Survey Miscellaneous Investigations Series Map I-1910, scale 1:250,000.

DeWitt, Ed, Redden, J.A., Wilson, A.B., and Buscher, David, 1986, Mineral resource potential and geology of the Black Hills National Forest, South Dakota and Wyoming, with a section on Salable commodities, by John S. Dersch: U.S. Geological Survey Bulletin 1580,135 p., 4 plates.

DeWitt, Ed, Buscher, David, Wilson, A.B., and Johnson, Tom, 1988, Map showing locations of mines, prospects, and patented mining claims, and classification of mineral deposits in the Berne 7 1/2-minute quadrangle, Black Hills, South Dakota: U.S. Geological Survey Miscellaneous Field Studies Map MF-1978-L, scale 1:24,000.

Martin, J.E., Sawyer, J.F., Fahrenbach, M.D., Tomhave, D.W., and Schulz, L.D., 2004, Geologic map of South Dakota: South Dakota Geological Survey General Map 10, scale 1:500,000.

[www.jurassic2.sdgs.usd.edu/pubs/pdf/SDGeomap_20040630.pdf/]

Post, E.V., 1967, Geology of the Cascade Springs quadrangle, Fall River County, South Dakota: U.S. Geological Survey Bulletin 1063-L, p. 443-504, scale 1:24,000.

Redden, J.A., 1968, Geology of the Berne quadrangle, Black Hills, South Dakota: U.S. Geological Survey Professional Paper 297-F, scale 1:24,000.

Wilson, A.B., and DeWitt, Ed, 1995, Maps showing metallic mineral districts and mines in the Black Hills, South Dakota and Wyoming: U.S. Geological Survey Miscellaneous Investigations Series Map I-2445, scale 1:100,000.

Wolcott, D.E., Bowles, C.G., Brobst, D.A., and Post, E.V., 1962, Geologic and structure map of the Minnekahta NE quadrangle, Fall River and Custer Counties, South Dakota: U.S. Geological Survey Mineral Investigations Field Studies Map MF-242, scale 1:24,000. 
Attachment A. Legal description of non-Federal land considered in this exchange (provided by U.S. Forest Service), excluding Outstanding Rights and Reservations.

\section{$\underline{\text { EXHIBIT A }}$}

Property that non-Federal parties will consider exchanging: (SEE ATTACHED MAPS)

\section{TNC property}

\section{Black Hills Meridian, Custer County, South Dakota}

H.E.S. No. 351 located in the Southwest Quarter of the Southeast Quarter (SW1/4SE1/4) and the Southeast Quarter of the Southwest Quarter (SE1/4SW1/4) of Section 32 in Township 3 South, Range 3 East and in the Northeast Quarter (NE1/4) and the East Half of the Northwest Quarter (E1/2NW1/4) of Section 5 in Township 4 South of Range 3 East of the Black Hills Meridian, Custer County, South Dakota, as described in Patent reocrded in Deed Book 11, Page 456; EXCEPTING therefrom Tracts Ashlee and Britney of Kelley Subdivision located in said H.E.S. 351 , as shown on the amended plat filed in Plat Book 11, Page 451; and

H.E.S. No. 353 located in Sections 4, 5 and 9 in Township 4 South or Range 3 East of the Black Hills Meridian, Custer County, South Dakota, as described in Patent recorded in Deed Book 11, Page 519; EXCEPTING therefrom Tract A of said H.E.S. No. 353, as shown on the plat filed in Plat Book 4, Page 149; AND EXCEPTING therefrom Tract B of said H.E.S. 353, as shown on the plat filed in Plat Book 6, Page 112.

Containing 237.6 acres, more or less.

\section{Wood property}

\section{Black Hills Meridian, Custer County, South Dakota}

\section{T. 6 S., R. 5 E.,}

Sec. 31, East Half of the Southeast Quarter (E1/2SE1/4)

Sec. 32, Southwest Quarter (SW1/4) and the West Half of the Southeast Quarter (W1/2SE1/4)

Containing 320.0 acres, more or less.

Containing an aggregate of 557.6 acres, more or less.

Land reservations of the non-Federal parties, exceptions to title

Reservations: None 
Attachment B. Legal description of Federal land considered in this exchange (provided by U.S. Forest Service), excluding Outstanding Rights and Reservations.

\section{EXHIBIT B}

Property that the U.S.D.A Forest Service will consider exchanging: (SEE ATTACHED MAPS)

\section{Black Hills Meridian, Fall River and Custer Counties, South Dakota}

\section{Buck Canyon property}

T. 8 S., R. 4 E.

Sec. 14, SW1/4NE1/4.

Containing 40.0 acres, more or less, in Fall River County.

\section{Green Canyon property}

T. 9S., R. 6E.

Sec. 6, Lot 5 .

Containing 33.69 acres, more or less, in Fall River County.

\section{Cattail property}

T. 8 S., R. 4 E.

Sec. $24, \mathrm{~N} 1 / 2 \mathrm{SE} 1 / 4$.

T. 8 S., R. 5 E.

Sec. 19 , lots 3 and 4 .

Containing 159.92 acres, more or less, in Fall River County.

\section{Ruby Creek property}

T. 3 S., R. 4 E.

Sec. 9, lot 4;

Sec. 16, lots 3 and 9, and E1/2NW1/4.

Containing 110.83 acres, more or less, in Custer County.

\section{Argyle property}

T. 6 S., R. 4 E.

Sec. 23, SE1/4SE1/4;

Sec. 24, S1/2NE1/4, N1/2SW1/4, S1/2SW1/4 and SE1/4.

Containing 440.0 acres, more or less, in Custer County.

Containing an aggregate of 784.44 acres, more or less. 


\section{Attachment C. Report request (provided by U.S. Forest Service).}

$\begin{array}{lll}\text { United States } & \text { Forest } & \text { Rocky } \\ \text { Department of } & \text { Service } & \text { Mountain } \\ \text { Agriculture } & & \text { Region }\end{array}$

Department of

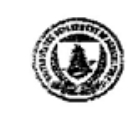

\section{.}

$-1$

File Code: $5430-2-1$
Date:

Anna Wilson

Geologist

U.S. Geological Survey MS 905

Central Mineral Resources

Box 25046, Denver Federal Center

Denver, CO 80225

Dear Ms. Wilson:

The Nature Conservancy, a nonprofit corporation of the District of Columbia, of 8100 Sheridan Lake Road, Rapid City, SD 57702, and Oonagh Wood and Leonard J. Wood, of Pringle, SD, have offered certain non-Federal lands within the Black Hills National Forest, in exchange for Federal lands also within the Black Hills National Forest. These lands are generally described in Exhibits A and B enclosed herewith. The lands to be exchanged are depicted on the maps also provided.

In accordance with the working agreement under Public Law 86-509, please provide a report on the locatable mineral resources on the lands described in Exhibits A and B. Please specify in your report the mineral or minerals involved. Please send your report to the letterhead address.

If you have any questions, you may contact Nancy Hollenkamp at (303) 275-5382.

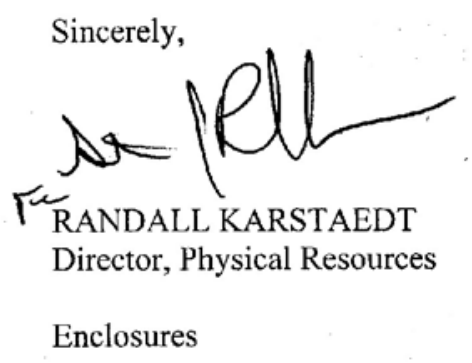

cc: Glenn Kostelecky 
Attachment D. Simplified geologic map (after Martin and others, 2004) showing the approximate location of the TNC (Lithograph) and Ruby Creek properties in the Jewel Cave and Berne quadrangles. The TNC (Lithograph) property is entirely within Pennsylvanian to early Permian Minnelusa Formation (PIPm). The Ruby Creek property is in Proterozoic metamorphosed black shale (Xbs) and metamorphosed tuffaceous shale (Xms).

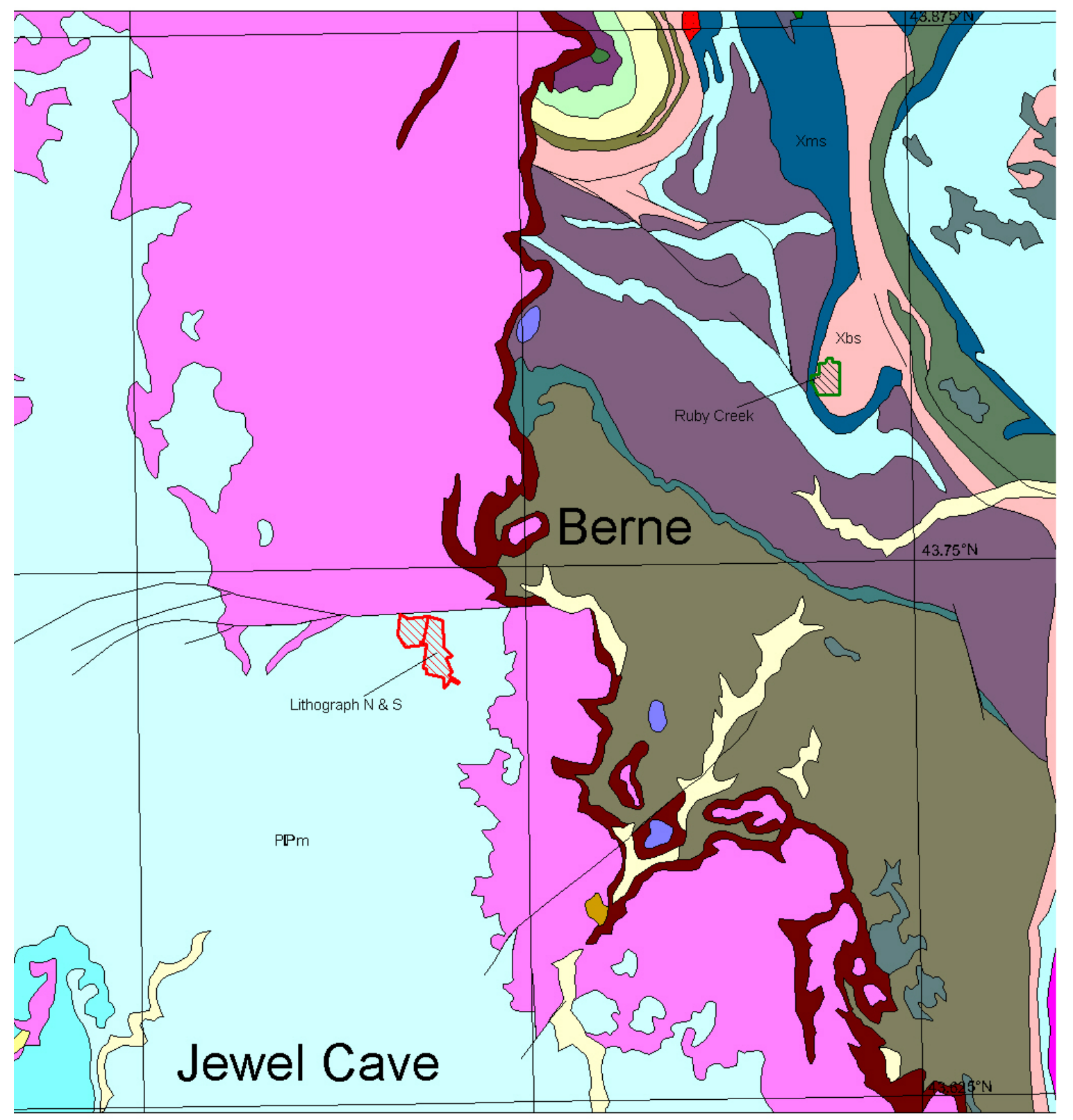


Attachment E. Simplified geologic map (after Martin and others, 2004) showing the approximate location of the Wood (Bogli Ranch) and Argyle properties in the Minnekahta NE and Pringle quadrangles. Both properties are entirely within Pennsylvanian to early Permian Minnelusa Formation (PIPm).

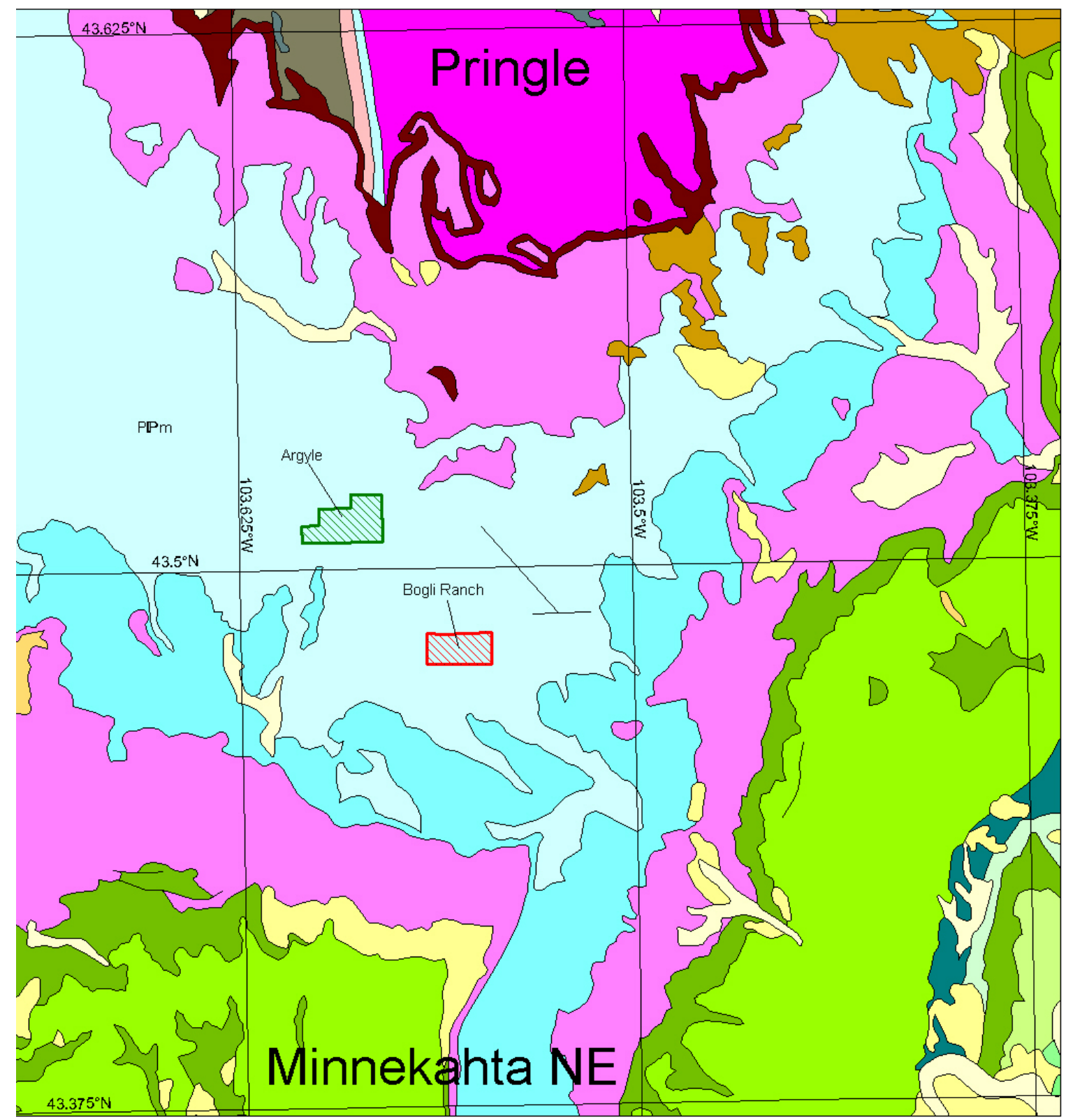


Attachment F. Simplified geologic map (after Martin and others, 2004) showing approximate location of Black Canyon, Cattail, and Green Canyon properties. On this simplified geologic map, all three properties are shown entirely within the Fall River and Lakota Formations (Kfl) of the Lower Cretaceous Inyan Kara Group.

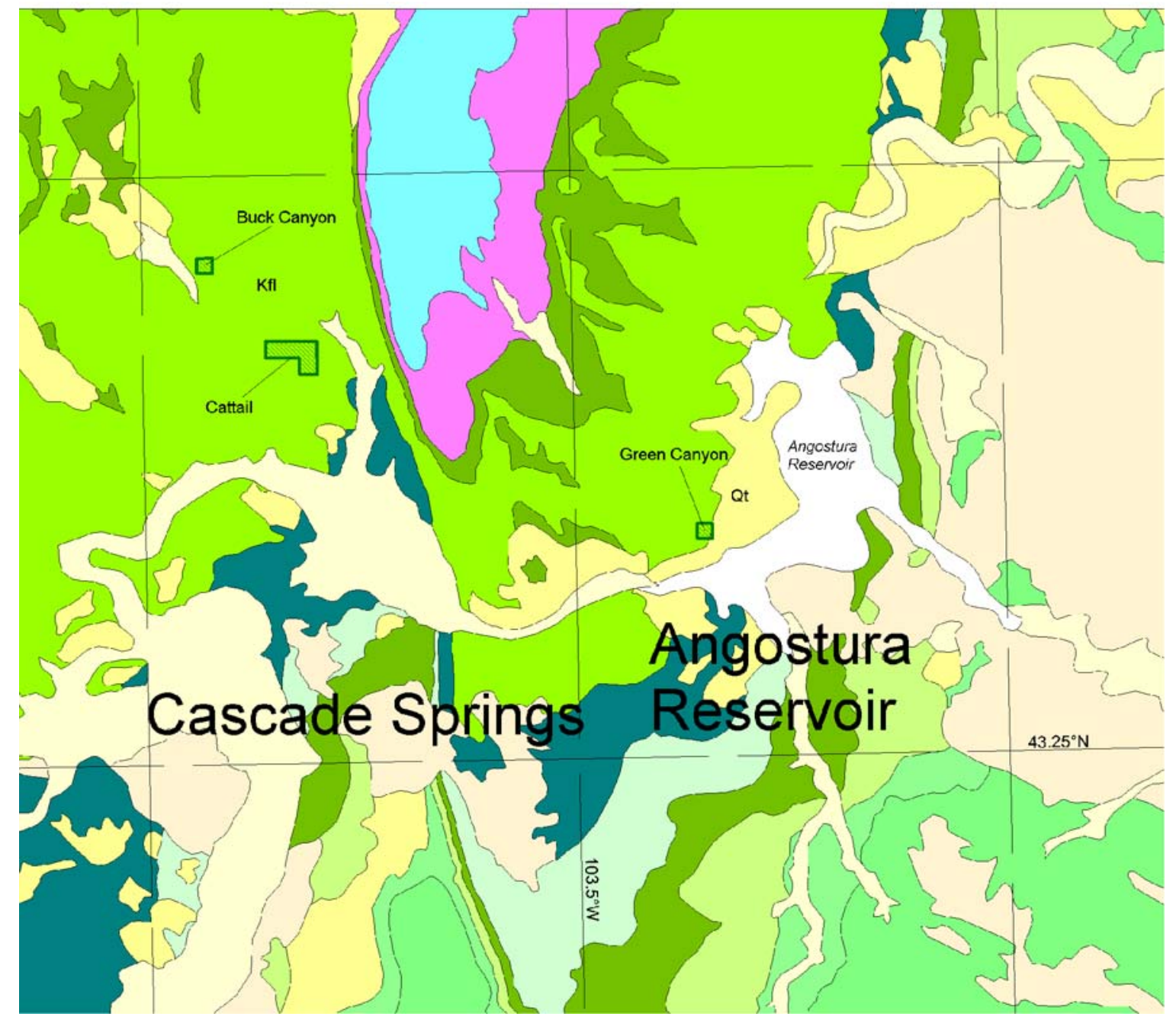




\section{LOCATABLE MINERAL REPORT FOR THE COLE DRAW (EDOFF) EXCHANGE OFFER, BUFFALO GAP NATIONAL GRASSLAND, NEBRASKA NATIONAL FOREST, PENNINGTON AND CUSTER COUNTIES, SOUTH DAKOTA}

By

Anna B. Wilson

U.S. Geological Survey

Administrative Report

March 24, 2003

The following report is based on information contained in USGS mineral resource and commodity files, mineral information databases (MRDS and MAS), and on reports and maps available in the USGS library. These data are occasionally augmented with unpublished documents, personal communications, and professional experiences. No field studies or on-site visits were performed in preparing this report. Emphasis is primarily on locatable mineral resources. Leasable and salable resources are covered only if they appear in the above documents. Mineral resource assessments are subjective: the opinions expressed herein are entirely those of the author. 


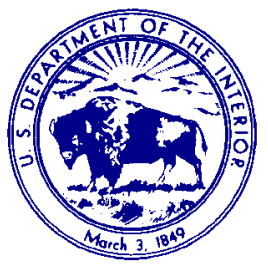

U.S. Department of the Interior

U.S. Geological Survey

Box 25046, MS 964

Denver Federal Center

Denver CO, 80225

(303) 236-5593

FAX (303) 236-3200

awilson@usgs.gov

March 24, 2003

Mr. M. M. Underwood

Director, Physical Resources

U.S. Forest Service

PO Box 25127

Lakewood, CO 80225-0127

Dear Mr. Underwood:

This report is in response to your January 6 request for information on locatable mineral resources in a land exchange proposal in which Lorence, Scott, and Veronica Edoff have offered certain non-Federal lands within Buffalo Gap National Grassland in exchange for Federal lands also within Buffalo Gap National Grassland, Nebraska National Forest.

In accordance with our long-term working agreement under Public Law 86-509, we are providing you with a report on the locatable mineral resources on the lands described in Exhibits $\mathrm{A}$ and $\mathrm{B}$, which were included with your request. These lands comprise 1,634.32 acres in Pennington and Custer counties, South Dakota.

Sincerely yours,

Anna B. Wilson, Geologist

Mineral Resources Program, Central Region

Copies: $\quad$ W.C. Day

E.A. du Bray

N. Hollenkamp

J.S. Dersch 
For the legal location description of lands considered for exchange, refer to Exhibits A and B in Attachments A and B. Original report request is in Attachment C.

\section{Non-Federal Lands}

Scenic SW, Creston 1:24,000, Wall 1:100,000, Hot Springs 1:250,000 quadrangles.

The southern parcel is mapped by King and Raymond (1971) as Cretaceous Pierre Shale (Attachment D), described as "black shale containing layers with large calcareous concretions and marine fossils.

The northern parcel is not mapped at detailed scale. Extrapolating from the King and Raymond map and comparing it to the State-scale geologic map suggests that the parcel may also be Pierre Shale. Without more detailed maps or a site visit, this is purely hypothetical.

\section{Federal Lands}

Scenic SW, Folsom, and Creston 1:24,000, Wall 1:100,000, Hot Springs 1:250,000 quadrangles.

All of the Federal parcels are mapped (King and Raymond, 1971) as Cretaceous Pierre Shale (see description above). It is expected that the parcels along the Cheyenne River are overlain by Quaternary deposits, but the geologic map does not show these units.

\section{Mineral Assessment for all Lands in the Exchange}

There are no known locatable mineral deposits near the parcels involved in the exchange (McFaul and others, 2000; Causey, 1998, Frank, 1999). The potential for locatable mineral resources is low. 


\section{REFERENCES:}

Causey, J. D., 1998, MAS/MILS mineral location database information: U.S. Geological Survey, Spatial Data Delivery Website.

[No longer available online in this format]

Frank, D.G. , 1999, Mineral Resource Data System (MRDS) data in Arc View Shape File Format, for Spatial Data Delivery Project, 1999: Not a formal series. Data provided for Spatial Data Delivery Project sddmrds version 1.1 Mineral Resource Data System data for Spatial Data Delivery Project, February, 1999, U.S. Geological Survey, Spokane, Washington. [No longer available online in this format]

King, R.U., and Raymond, W.H., 1971, Geologic map of the Scenic area, Pennington, Shannon, and Custer Counties, South Dakota: U.S. Geological Survey Miscellaneous Geologic Investigations Map I-662, scale 1:31,680.

McFaul, E.J., Mason, G.T., Jr., Ferguson, W.B., and Lipin, B.R., 2000, U.S. Geological Survey Mineral Databases-MRDS and MAS/MILS: U.S. Geological Survey Digital Data Series DDS-52. [Use of this data CD is not recommended.]

\section{LIST OF ATTACHMENTS:}

A. Exhibit A, Non-Federal land (provided by U.S. Forest Service).

B. Exhibit B, Federal land (provided by U.S. Forest Service).

C. Report request (provided by U.S. Forest Service)

D. Geologic map showing location of parcels exclusive of non-Federal lands in T. 2 S., R. $12 \mathrm{E}$. 


\section{Attachment A. Exhibit A (provided by U.S. Forest Service) EXHIBIT A}

Property that the Non-Federal Party will consider exchanging:

N - 1: Lorence M. Edoff, Father and Scott M. Edoff, Son, As Tenants in Common.

Black Hills Meridian, Pennington County, South Dakota
T. 2 S., R. 12 E.,
Acres
sec. $7, \mathrm{SE}^{1 / 4}$;
160
sec. $8, W^{1} / 2 S W 1 / 4$;
80

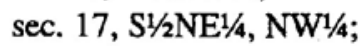
240
sec. $18, \mathrm{NE}^{1 / 4}$.
160

N - 2: Lorence M. Edoff, A Single Person: $1 / 2$ Undivided interest to Scott M. Edoff and Veronica A.

Edoff, Husband and Wife, as Joint Tenants with Rights of Survivorship and not as Tenants in Common.

Black Hills Meridian Pennington County, South Dakota

T. 3 S., R. 12 E., sec. $4, S^{1} 1 / 2 N W^{1} 1 / 4, E^{1} / 2 W^{1} / 4$.

The areas described aggregate 800.00 acres.

\section{THE EDOFF FAMILY HAS AGREED TO AND IS CURRENTLY WORKING WITH THEIR ATTORNEY TO HAVE TITLE TO THE ABOVE DESCRIBED NON-FEDERAL LAND VESTED INTO ONE ENTITY.}

Land reservations of the Non-Federal Party and exceptions to title:

Reservations: None

\section{Outstanding Rights:}

1. $\mathrm{N}-1 \& \mathrm{~N}-2$ : Statutory section line right-of-way 33 feet on either side of all section lines, pursuant to SDCL, Chapter 31-18.

\section{Other:}

1. If the mineral report shows that the locatable, leasable, and salable potential is low and the appraisals show there is no mineral value, the non-Federal parties will convey minerals.

2. Real Estate Mortgage dated May 29, 1992, executed by Scott M. Edoff and Veronica A. Edoff, husband and wife, and Lorence M. Edoff and Wanda L. Edoff, husband and wife, to Farm Credit Bank of Omaha to secure the payment of $\$ 220,000.00$ plus interest, filed June 1, 1992 and recorded in Book 45 of Mortgages on page (s) 9250 in the Office of the Register of Deeds, Pennington County, South Dakota, shall be released at or prior to closing. 


\section{Attachment B. Exhibit B (provided by U.S. Forest Service)}

\section{EXHIBIT B}

The following is the legal description of the Federal parcels to be conveyed:

Black Hills Meridian Custer County, South Dakota

T. 3 S., R. 11 E., Acres sec. $1, \mathrm{SW}^{1 / 4} \mathrm{SE}^{1 / 4}, \mathrm{NW}^{1 / 4} \mathrm{SE}^{1 / 4} ; \quad 80$ sec. 12, SE1/4NE1/4, NE $1 / 4 \mathrm{SE}^{1 / 4}$; sec. 13, NW1/4NE1/4, SW1/4NE1/4, NE1/4NW1/4, SE1/4SW1/4. 160

T. 3 S., R., 12 E., sec. $6, N^{1} 1 / 4 N^{1} 1 / 4$.

T. 2 S., R. 12 E., sec. 31 , lots $1,2,3$, and $4, E^{1} / 2 W^{1} 1 / 4, N^{1} / 4 S^{1} 1 / 4, S^{1} 1 / 4 S^{1} / 4, S^{1} / 2 E^{1} / 4$, $\mathrm{NW}^{1 / 4} \mathrm{SE}^{1 / 4}$ sec. 33 , lot 4 .

\section{Black Hills Meridian, Pennington County, South Dakota}

T. 2 S., R. 12 E., sec. 21 , lot 1 .

The areas described aggregate 834.32 acres.

\section{Reservations: None}

\section{Outstanding Rights: None}

\section{Other:}

1. If the mineral report shows that the locatable, leasable, and salable potential is low and the appraisals show there is no mineral value, the United States will convey minerals.

2. Special Use Permit issued for a buried telephone cable to Fort Randall Telephone Co. shall be waived and a replacement easement shall be issued by the non-Federal party at or prior to closing. 


\section{Attachment C. Report request (provided by U.S. Forest Service)}

$\begin{array}{lll}\text { United States } & \text { Forest } & \text { Rocky } \\ \text { Department of } & \text { Service } & \begin{array}{l}\text { Mountain } \\ \text { Region }\end{array} \\ \text { Agriculture } & & \end{array}$

Anna Wilson

Geologist

Central Mineral Resources

U.S. Geological Survey MS 905

Box 25046, Denver Federal Center

Denver, CO 80225

Dear Ms. Wilson:

Lorence M. Edoff, and Scott M. and Veronica A. Edoff, husband and wife, all as joint tenants, of Hermosa, South Dakota, have offered certain non-Federal lands within the Buffalo Gap National Grassland, administered by the Nebraska National Forest, in exchange for Federal lands also within the Buffalo Gap National Grassland, administered by the Nebraska National Forest. These lands are generally described in Exhibits A and B enclosed herewith. The lands to be exchanged are depicted on the maps also provided.

In accordance with the working agreement under Public Law 86-509, please provide a report on the locatable mineral resources on the lands described in Exhibits A and B. Please specify in your report the mineral or minerals involved. Please send your report to the letterhead address.

If you have any questions, you may contact Nancy Hollenkamp at (303) 275-5382.

Sincerely,

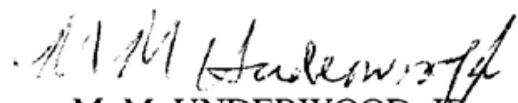

M. M. UNDERWOOD, JR.

Director, Physical Resources

Enclosures

cc: Kevin Heikkila
P.O. Box 25127

Lakewood, CO 80225-0127

Delivery: 740 Simms Street

oice: 303-275-5350

File Code: $5430-2-1$

Date:

JAN - 62003 
Attachment D. Geology of the Scenic area (after King and Raymond, 1971). Green area is Cretaceous Pierre Shale, yellow is Oligocene Chadron Formation. Thin band of grass green barely visible between the two units is upper part of Pierre shale where highly colored shale formed from Eocene weathering to a maximum depth of 300 feet.

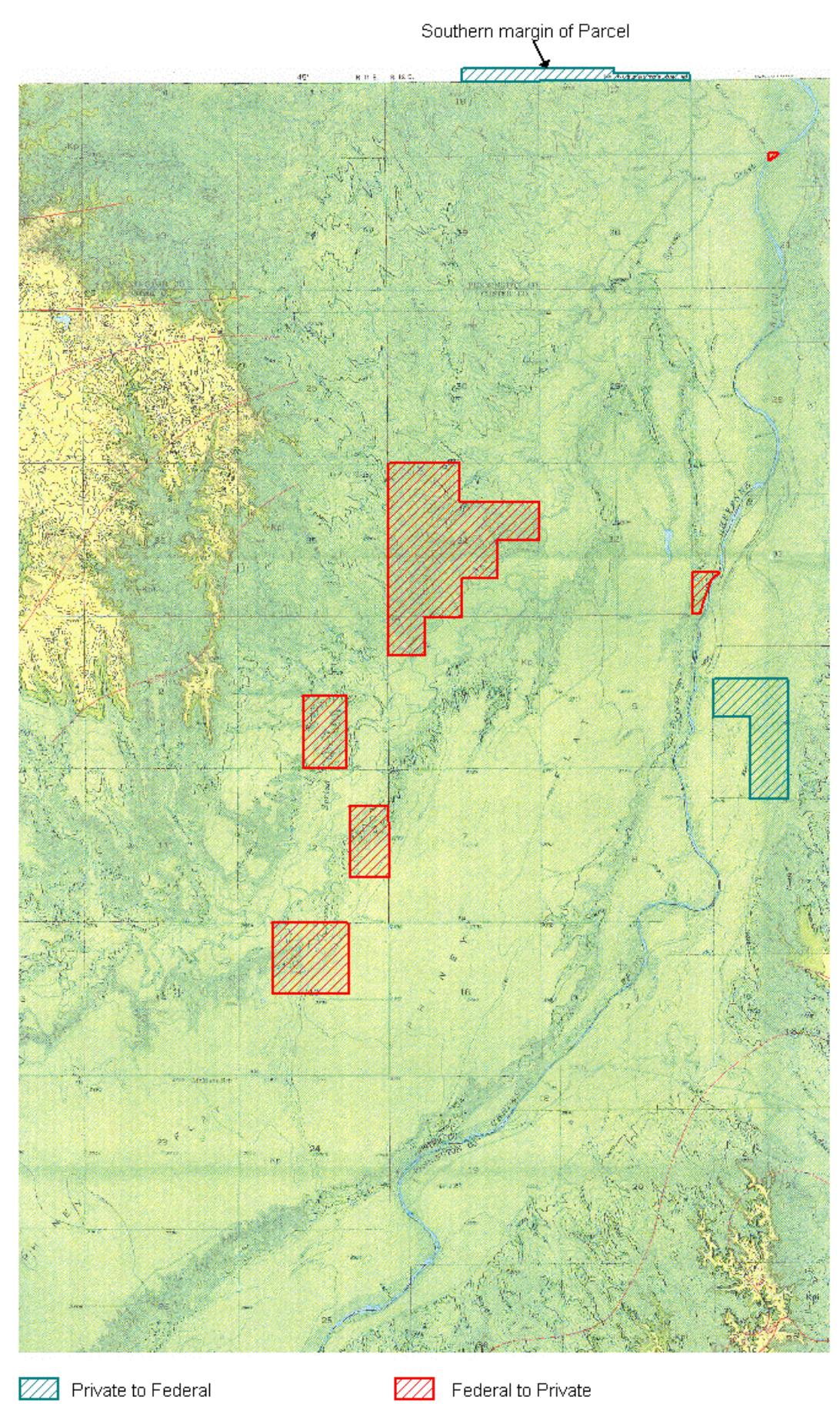




\title{
LOCATABLE MINERAL REPORT FOR THE \\ CORTNEY CREEK (SIDES RANCH) EXCHANGE OFFER, BUFFALO GAP NATIONAL GRASSLAND, NEBRASKA NATIONAL FOREST, FALL RIVER COUNTY, SOUTH DAKOTA
}

\author{
By \\ Anna B. Wilson \\ U.S. Geological Survey \\ Administrative Report
}

September 30, 2004

The following report is based on information contained in USGS mineral resource and commodity files, mineral information databases (MRDS and MAS), and on reports and maps available in the USGS library. These data are occasionally augmented with unpublished documents, personal communications, and professional experiences. No field studies or on-site visits were performed in preparing this report. Emphasis is primarily on locatable mineral resources. Leasable and salable resources are covered only if they appear in the above documents. Mineral resource assessments are subjective: the opinions expressed herein are entirely those of the author. 


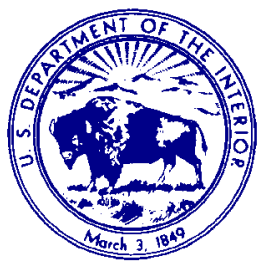

U.S. Department of the Interior

U.S. Geological Survey

Box 25046, MS 964

Denver Federal Center

Denver CO, 80225

(303) 236-5593

FAX (303) 236-3200

awilson@usgs.gov

September 30, 2004

Mr. Randall Karstaedt

Director, Physical Resources

U.S. Forest Service

PO Box 25127

Lakewood, CO 80225-0127

Dear Mr. Karstaedt:

This report is in response to your August 11 request for information on locatable mineral resources in a land exchange proposal in which Sides Ranch, Inc. has offered certain non-Federal lands within Buffalo Gap National Grassland in exchange for Federal lands also within Buffalo Gap National Grassland (administered by Nebraska National Forest).

In accordance with our long-term working agreement under Public Law 86-509, we are providing you with a report on the locatable mineral resources on the lands described in Exhibit B, which was included with your request. These lands comprise 658.78 acres in Fall River County, South Dakota. No report was requested for land in Exhibit A.

Sincerely yours,

Anna B. Wilson, Geologist

Mineral Resources Program, Central Region

Copies: $\quad$ C.J. Nutt

N. Hollenkamp

J.S. Dersch 
A location map is in Attachment A. For the legal location description of lands considered for exchange, refer to Exhibit B in Attachment B. The original report request is in Attachment C.

\section{Federal Lands}

Hay Butte Canyon 1:24,000, Hot Springs 1:100,000, Hot Springs 1:250,000 quadrangles.

The parcel is not mapped at detailed scale. At 1:500,000, entire parcel is mapped by Martin and others (2004) as Upper Cretaceous Pierre Shale. This shale unit is blue-gray to dark-gray, fissile to blocky shale with persistent beds of bentonite, black organic shale, and light-brown chalky shale. It may contain minor sandstone, conglomerate, and abundant carbonate and ferruginous concretions (Martin and others, 2004). Although this area is shown on several small scale or state-wide geologic map compilations (Martin and others, 2004; Ellis and Colton, 1994, DeWitt and others, 1989), it does not appear that any new geologic field mapping has been published in this area since 1902 (Darton, 1902). No larger scale maps of this area could be located.

There are no known locatable mineral deposits near the parcels involved in the exchange (U.S. Geological Survey, 2004). The potential for locatable mineral resources is considered to be low.

\section{REFERENCES:}

Darton, N.H., 1902, Oelrichs [quadrangle], South Dakota: U.S. Geological Survey Geological Atlas of the United States, Folio 85, scale 1:250,000.

DeWitt, Ed, Redden, J.A., Buscher, D.P., and Wilson, A.B., 1989, Geologic map of the Black Hills area, South Dakota and Wyoming: U.S. Geological Survey Miscellaneous Investigations Series Map I-1910, scale 1:250,000.

Ellis, M.S., and Colton, R.B., 1994, Geologic map of the Powder River basin and surrounding area, Wyoming, Montana, South Dakota, North Dakota, and Nebraska: U.S. Geological Suvey Miscellaneous Investigations Series Map I-2298, scale 1:500,000.

Martin, J.E., Sawyer, J.F., Fahrenbach, M.D., Tomhave, D.W., and Schulz, L.D., 2004, Geologic map of South Dakota: South Dakota Geological Survey General Map 10, scale 1:500,000.

U.S. Geological Survey, 2004, Mineral resources on-line spatial data, http://mrdata.usgs.gov/

\section{LIST OF ATTACHMENTS:}

A. Generalized location map (provided by U.S. Forest Service).

B. Exhibit B, Federal land (provided by U.S. Forest Service).

C. Report request (provided by U.S. Forest Service) 


\section{Attachment A. Generalized location map (provided by U.S. Forest Service)}

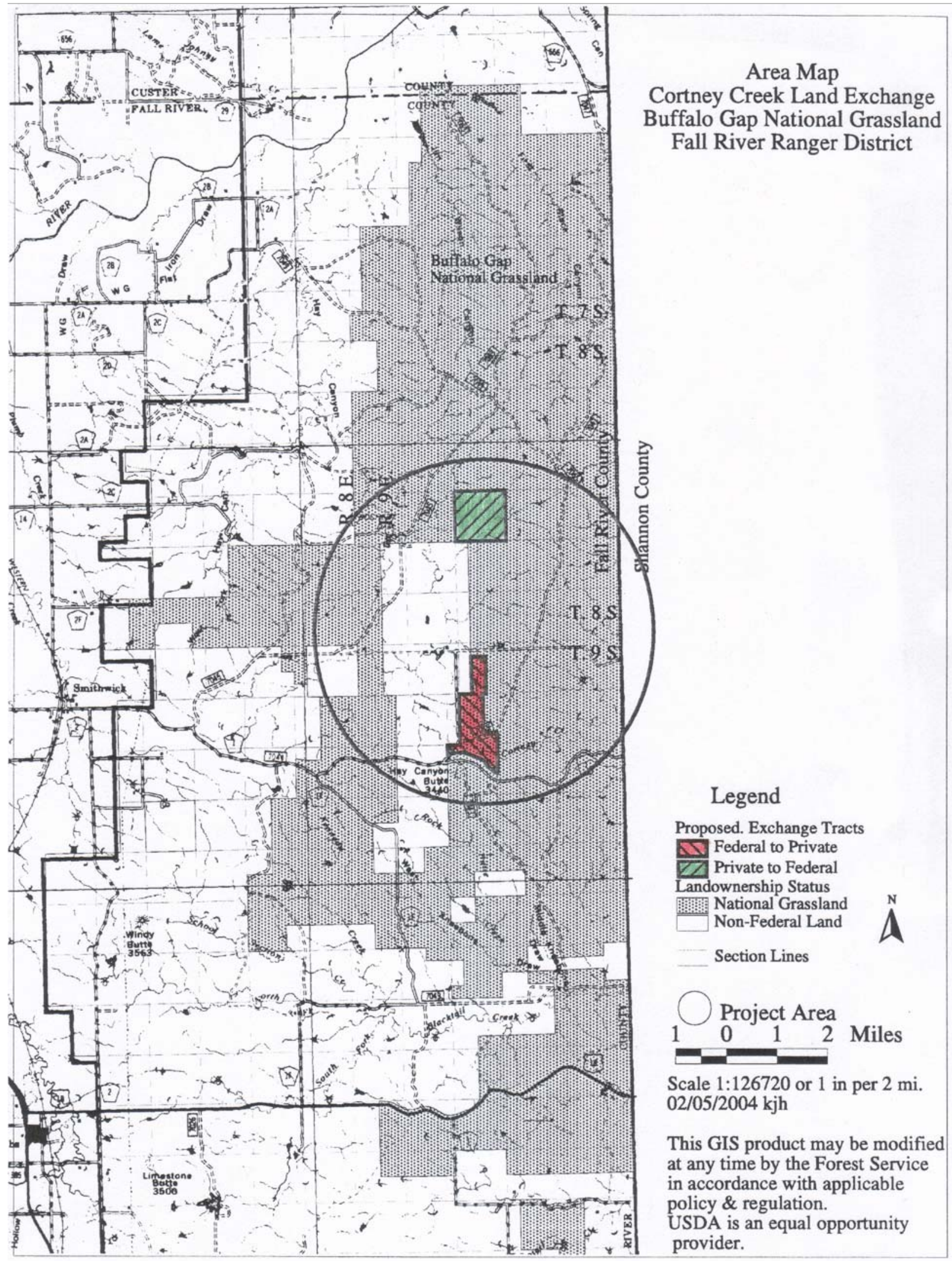




\title{
Attachment B. Exhibit B (provided by U.S. Forest Service)
}

\author{
$\underline{\text { EXHIBIT B }}$
}

Property that the U.S.D.A. Forest Service will consider exchanging:

T. 8 S., R. 9 E.;

\author{
Black Hills Meridian, Fall River County, South Dakota
}

Sec. 33: SE1/4NW1/4, E1/2SW1/4

T. 9 S., R. 9 E.;

Sec. 4: Lots 2 and 3, ,SE1/4NW1/4, E1/2SW1/4,SW1/4NE1/4,W1/2SE1/,SE1/4SE1/4.

Sec. 9: All of that portion of the North $1 / 2$ lying northerly and easterly of the northerly right-of-way line of Fall River County road No. 1 containing 175.46 acres and

All of that portion of the Southeast $1 / 4$ lying northerly of the centerline of Fall River County road No. 1. containing 3.62 acres of which 0.61 acres lies beneath the Right-of-Way.

The areas described aggregate 658.78 acres.

Land reservations of the U.S.D.A. Forest Service, exceptions to title and uses to be recognized:

\section{Reservations:}

1. Reserving to the United States of America a right-of-way thereon for ditches or canals constructed by the authority of the United States Act of August 30, 1890 (26 Stat. 391; 43 U.S.C. 845).

2. EXCEPTING AND RESERVING TO THE UNITED STATES, and its permittees, contractors and assigns, a perpetual easement, for an existing road (Forest Roads 7045), and all appurtenances thereto, along and across a strip of land, hereinafter defined as the "premises", together with such reasonable rights of temporary use of land immediately adjacent to said right-of-way as may be necessary for the maintenance and/or repair of said

road. Said easement being 2467.48 feet in length with a width of sixty-six (66) feet (33 feet on each side of centerline) and contains 3.74 acres, more or less of the existing road, with such additional width as is necessary to accommodate and protect cuts and fills, over and across portions of the E1/2SW1/4 and the W1/2SE1/4, Section 4, T9S, R9E, BHM, Fall River County, South Dakota for the existing, which provides public and administrative access to existing NFS land immediately east of the above described property. Said right of way is attached Exhibit "A" Road Right of Way Survey Located in the E1/2SW1/4 and the W1/2SE1/4, Section 4, T9S, R9E, BHM, Fall River County, South Dakota, dated February 3, 2003 by Ralph W. Turner, Registered Land Surveyor.

Road Rights-of-Way: Reserving to the United States of America a right-of-way within 
The said easement hereby reserved is for the construction, reconstruction, maintenance, and full, free, and quiet use and enjoyment of a road or as it shall be located and constructed the above deseribed premises.

The word "premises" when used herein means said strip of land, whether or not there is an existing road located thereon. Except where it is defined more specifically, the wor

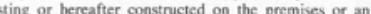
segment of such roads.

If the road is located substantially as described herein, the centerline of said road is as constructed is hereby deemed accepted by the Unired States/Forest Service and the Patentee as the true centerline of the premises reserved. If any subsequent survey of the road shows that any portion of the road, although located substantially as described, crosses lands of described herein, the casement shall be amended to include the additional lands traversed, if any lands described herein are not traversed by the road as constructed, the

The United States alone may extend rights and privileges for use of the prenives to other Government departments and azencies. States, pat heal sublivisions theneof, and to other users including members of the public.
und

The United States shall have the right to use the road on the premises without costs for all purposes deemed necessary of desirable in connection with the protection. administration. management and utilization of its lands or resources, now or hereafter owned or controliced. subject to such traffic-control regulations and rulcs at may reasonably impose upon of shall be responsible for all costs of construction, reconstruetion, repair and maintenance of the road.

The United States shall have the right to cut timber upon the premises to the extent necessary for constructing, reconstructing, and maintaining the road. Timber so cut shall,
unless otherwise agreed to, be cut into logs of lengths specified by the timber owner and decked along the road for disposal by the owner of such timber.

The Patentee has the right to use the road hereinafter to be constructed for all purposes deemed necessary or desirable by Patentee in connection with the protection, hereafter owned or controlled, subject, however, to traffice-control regulations as the United and the sharing of the cost of construction or reconstruction proportionate to use, in each case as authorized and provided by the regulations of the Secretary of Agriculture and as they may be amended and published in the Code of Federal Regulations.

Patentee has the right wo cross and rectoss the premises and road at any place by any
reasomable means and for any purpose in sach manner as will not interfere unreasonably with use of the road.

Patentec has the right to all timber now or hereffter growing on the premises, subject to the PROVIDED, that if the Regional Forester determines that the road, or any segment thereof. is no longer needed. for the purposes rescred, the essement shall temniaste. The Iermination shall be evisence by a

The foregoing reservation is in accordance with the provisions of the Act of February 28 ,
1925 ( 43 U. S.C. 486).

Waterline Rights-of-Way: Reserving to the United States of America a right-ofway within the NEy/SW/4 and the NW/4SE/4, Section 4, T9S, R9E, BHM Fall River County, South Dakota for an existing waterline that provides stockwater through the Forest Service, United States Department of Asriculture, and its assigns also rosest Service, to this existing waterline for its continued operation and maintenanoc. Said right of way is 1749.28 feet in length with a width of 50 feet (25 feet on each side of centerline) and contains 2.0 acres, more or less of the existing waterline. Reference Exhibit "B" Waterline Right of Way BHM Fall River county, South Dakota, deted January 30, 2003 by Ralph W. Turner, Registered Land Surveyor.

4. U. S. Water Right № $376-2$ Certificate of Construction of Works and Appropriation LUSD-T Job No. 223-120A dated Oetober 25, 1937 withdrawing from further appropristion 29.21 acre-feet per annum of water for storage; of waters of a dry draw in the county of $1920^{\circ}$ from the West Quanter Corner (W/6) of Township 8 South, Range $9 \mathrm{E}$ Esst, Section 33. Black Hills Meridian.

5. The United States Depantment of Agriculture, Fores Servize reserves unto itelf all right and titk to any and all features and artifiacts asvociated with Archneological Site

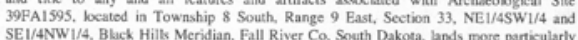

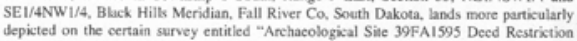

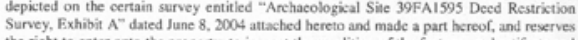
Survey, Exhibit A dated lune 8, 2004 attashed hereto and made a part hereof, and reserves
the right to chater onto the property, to inspect the condition of the features and artifiacts and the ascociated surface, and to remove said artifucts at any reasonable time upon writtea
notice to the owner of record. Reference the attached Exhibit "B" Archneological Site
39FA A 595 Deed Restriction Administrative Acesess Right of Way. dated Juas 8, 2004 . The Grantec, successors, heirs, and assigns covenant to maintain and preserve and not

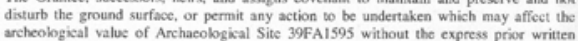
archeological value of Archacelogical Site $39 F A 1595$ without the experess proior written
permission of the United States Department of Agriculure. Forest Service signed by a fully permission of the United States Deparment of Agricullure. Forest Service signed by a fully
authorized representative thercof, with concurrence of the South Dakota State Hisotric Preservation OAficer.

The Partics agree and acknowledge that the photograph(s) referencing site 39FA1595,

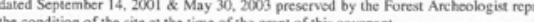

In the event of violation of any of the conditions, covenants, or restrictions in this instrument, whenever reasonably possible, the United States Department of Agriculture,
Forest Service will seve potice Forest Service will serve notice upon the owner of record, to cure sach violation. In the
event the viobtion is not cured within a reasonable time or that circumstances do not permit notice, the United States Department of Agriculture, Forest Service may enjoin said violation of take any other appropriate legal action. The owner of recond will be responsible and liable for all legal coses and expenses incurred in connection with such a
suit, including but not limited to court costs and attomey fees.

prior notice to the Grantee, convey agriculture, Forest Servise may at ins discretion, wihtout prior notice to the Grantee, conveys
contained herein to a third party.

The failure of the Unitcs States Deparment of Agriculure, Forest Service to exercise any right or remedy granted under this instrument shall not have the effect of waiving or
limining the exereise of any other right or remedy or the use of such right or remedy 11 any other time.

If the appropriate Regional Forester deternines that protection for Arehasological Site $39 F A 1595$ of any part thereof is no longer needed or necessary, with consurrence of the
South Dakota State Hiotric Proservation Officec, the reserved rights stendant protective covenans, sall temminate. Evidenec for such sermination shall be a statemeat in recordable form furnished by the appropriate Regional Forester to the
Grantors their heirs. we cecsors or assigns in interes. This reservation and accompanying covenants shall be a binding servitude upon the above-
described property and shall be deemed to run with the land. Execution of this deed shall

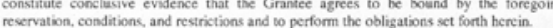

Outatanding Rixhts:

The rights of the United States and third parties recited in the patent from the United State.

Right-of-way easements for roads and highways granted, created or established by or otherwise, prior to the conveys
BHM Sec. 33, SEMANW/4.)

Right to any gravel for county purposes served by Fall River County, South Dakota, B.H.M., as follows:

Why of Section 33, by county deed dated March 8, 1945, recorded in the Office of Register of Deeds in Book 58 of Deeds at Page 408.

Right-of-way easement for public road and highways granted under the Act of October 13, 1964 from the United States of America to the county of Fall Raver of the State of South Dakota, datod August $1^{*}, 1983$. Subject to specified terms, provisions, and conditions. Affecting T. $9 \mathrm{~S}$, R. 9 E., Sec, 4, W1/2 (Fall River Co a/k/a Sides Ranch Road.

Rights of T.P.Fenton of Rapid City, South Dakota, under an oil and gas lease granted
to him by Fall River County, South Dakota, dated May 9, 1944, recorded in the OFie of the Register of De the NE1/ and the NW14 of Section 33, Township 8 South, Range 9 East (with other lands totaling 2440 acres) for the production, saving and taking care of oil, gas casinghead gas, easinghead gasoline and the injection of water, brine and other fluids into this surface strats, for a period of 10 years from the date of the lease or so long as oil, gas, casinghead gas, etcetera, is produced from the said lands of drilling one year from the date of the lease, the lease shall terminate unless the lessee pays the lessor ten cents per acre annually which shall operate as a rental to cover the privilege of deferring the commencement of a well for twelve months from ssid date. (Affects T. 8 S., R. 9E., BHM Sec. 33, SEYNWW.) Note: Ray S. Sides, decensed, and Helen Sides are the preents oc John S. Sides, President of Sides Ranch, inc. They conveyed this land, among other lands to the United States by Warranty Deed on

Rights of J.A.Pfeiler of Hot Springs, South Dakota, under a mineral deed dated October 1, 1945, recorded in the Office of the Register of Deeds in Book 230\% Miscellaneous at Pages 391 and 392, granted to him by Ray S. Sides and Helen M. Sides, husband and wife, conveying "all interest in and to all of the oil and gas and other minerals in and under and that may be producod from the following described lands situated in Pall River county, State of South Dakota, to-wit, North Half,

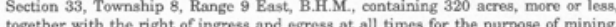
drilling, exploring, opernting and developing said lands for oil, gas and other minerals and storing, handling, transporting and marketing the same therefrom with the right to remove from said land all the grantees property and improvements. (Affects T. 8 S., R. 9E., BHM See. 33, SEYNWW,.) Note: Ray S. Sides, deceased, and Helen Sides are the parents of John S. Sides, President of Sides Ranch. Inc. They
conveyed this land, among other lands to the United States by Warranty Deed on December 17,1948 .

Fall River County Road \#1: To Fall River County Commissioners a Public Road the existing Fall River County Road $\# 1$ located in T. 9. S., R. 9 E., Section 9, NE1/4NE1/4.

Other:

Special Use permit: To Golden West Telephone Co. dated October 6, 1995 will be to delete buried telephone line in T. 9. S., R. 9 E., Sec 9 NW1/4NW $1 / 4$ located northerly and easterly of Fall River Co. Rd. $1 \mathrm{E}$.
continuod use of this portion of line will be executed at closing.

Special Use permit: To Fall River Water Users District dated November 16, 2000

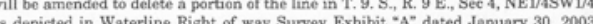
Balph W. Tumer LS 4093. An Easement for the continued use of this portion of line will be executed at closing.

Water Rights: Federal Land - T.8S, R9E. Sec. 33 NE1/4SW1/4, U.S. Water Right No. 376-2- Location Notice is dated June 29, 1937 by Oxcar Hermstad, Project Manager, Badlands. will be reserved by the United States of America

An Agreemeat between the USDA Forest Service and Sides Ranch, Inc. will be executed at closing to allow for the continued use of the resern
by Sides Ranch, lac specifically to water livestock.

Livestock Graxing Permits: The USDA Forest Service will provide materials for a catte guard to be installed by Sides Ranch, Inc. to be placed on Forest Road 7045 where the nun-Federal land If the mineral report shows the locatable, leasable, and salable potential is low and If the mineral report shows the locatable, leasable, and salable potential is low and
the appraisal shows there is no mineral value, the United States will convey
minerals, not outstanding to third parties. 


\section{Attachment C. Report request (provided by U.S. Forest Service)}

$\begin{array}{lll}\text { United States } & \text { Forest } & \text { Rocky } \\ \text { Department of } & \text { Service } & \text { Mountain } \\ \text { Agriculture } & & \text { Region }\end{array}$

P.O. Box 25127

Lakewood, CO 80225-0127

Delivery: 740 Simms Street

Golden, CO 80401

Voice: 303-275-5350

TDD: $303-275-5367$

File Code: $5430-2-1$

Date:

Anna Wilson

AUG 112004

Geologist

Central Mineral Resources

U.S. Geological Survey MS 905

Box 25046, Denver Federal Center

Denver, CO 80225

Dear Ms. Wilson:

Sides Ranch, Inc., a South Dakota corporation, of P.O. Box 137, Smithwich, South Dakota 57782 , has offered certain non-Federal lands within the Buffalo Gap National Grassland, in exchange for Federal lands also within the Buffalo Gap National Grassland (administered by the Nebraska National Forest). These lands are generally described in Exhibits A and B enclosed herewith. The lands to be exchanged are depicted on the maps also provided.

In accordance with the working agreement under Public Law 86-509, please provide a report on the locatable mineral resources on the land described in Exhibit B. It is not necessary to provide a report for the land in Exhibit A since the minerals were retained in patent by the State of South Dakota and are not available to be exchanged to the United States. Please specify in your report the mineral or minerals involved. Please send your report to the letterhead address.

If you have any questions, you may contact Nancy Hollenkamp at (303) 275-5382.

Sincerely,

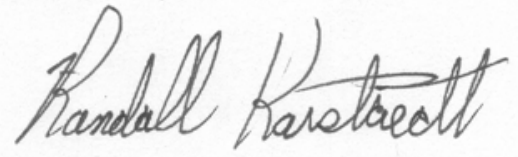

RANDALL KARSTAEDT

Director, Physical Resources

Enclosures

cc: Kevin Heikkila 


\title{
LOCATABLE MINERAL REPORT FOR THE INDIAN CREEK LAND EXCHANGE OFFER, BUFFALO GAP NATIONAL GRASSLAND, NEBRASKA NATIONAL FOREST, PENNINGTON AND CUSTER COUNTIES, SOUTH DAKOTA
}

\author{
By \\ Anna B. Wilson \\ U.S. Geological Survey \\ Administrative Report
}

January 6, 2005

The following report is based on information contained in USGS mineral resource and commodity files, mineral information databases (MRDS and MAS), and on reports and maps available in the USGS library. These data are occasionally augmented with unpublished documents, personal communications, and professional experiences. No field studies or on-site visits were performed in preparing this report. Emphasis is primarily on locatable mineral resources. Leasable and salable resources are covered only if they appear in the above documents. Mineral resource assessments are subjective: the opinions expressed herein are entirely those of the author. 


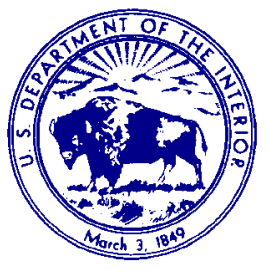

U.S. Department of the Interior

U.S. Geological Survey

Box 25046, MS 964

Denver Federal Center

Denver CO, 80225

(303) 236-5593

FAX (303) 236-3200

awilson@usgs.gov

January 6, 2005

Mr. Randall Karstaedt

Director, Physical Resources

U.S. Forest Service

PO Box 25127

Lakewood, CO 80225-0127

Dear Mr. Karstaedt:

This report is in response to your December 29 request (received January 5) for information on locatable mineral resources in a land exchange proposal in which the Dakota Partnership has offered certain non-Federal lands within Buffalo Gap National Grassland in exchange for Federal lands also within Buffalo Gap National Grassland (administered by Nebraska National Forest).

In accordance with our long-term working agreement under Public Law 86-509, we are providing you with a report on the locatable mineral resources on the lands described in Exhibits $\mathrm{A}$ and B, which were included with your request. These lands comprise 5,998 acres in Pennington and Custer Counties, South Dakota.

Sincerely yours,

Anna B. Wilson, Geologist

Mineral Resources Program, Central Region

Copies: $\quad$ C.J. Nutt

N. Hollenkamp

J.S. Dersch 
The original report request is in Attachment A. For the legal location description (exclusive of reservations and outstanding rights) of lands considered for exchange, refer to Attachments B and C. A simplified geologic map showing approximate parcel locations is in Attachment D.

\section{Non-Federal Lands}

Huetmacher Table, Scenic SW, and Sheep Mountain Table 1:24,000; Wall 1:100,000; Hot Springs 1:250,000 quadrangles.

The bedrock geology of all the non-Federal parcels was mapped at a scale of 1:31,680 (1/2 mile per inch) by King and Raymond (1971) and all of the rock unit descriptions that follow are from this map. In this region, Upper Cretaceous Pierre Shale, a black shale containing calcareous concretions and marine fossils, is locally capped with as much as $300 \mathrm{ft}$ of the "Interior Beds." Named for the town of Interior, this unit is composed of highly colored shales formed during the Eocene(?) from weathered the Pierre Shale. Oligocene Chadron Formation overlies the Pierre Shale (and Interior Beds). Chadron Formation is composed of gray to pink sandstone and clay, with locally prominent basal conglomerate and channel sandstone. It contains fossils of titanothere (an ancient rhino-like mammal). Oligocene Brule Formation tops the section. It contains pinkish-gray to greenish-gray clay, silt, sand, and volcanic ash containing channel sandstones, clastic dikes, and chalcedony veinlets. Oreodon (an ancient camel-like mammal) and turtle fossils are common in the Brule Formation.

Parcels:

P-1, on Zebell Table, contains all four of the above units (King and Raymond, 1971). However, at State-scale, this area is mapped as Quaternary eolian deposits that were deposited as sand sheets, dunes, and as a veneer on uplands (see Attachment D, after Martin and others, 2004).

P-2 is mostly Pierre Shale, with the three overlying units exposed near the south end (King and Raymond, 1971). The State-scale map (Martin and others, 2004) shows the northwestern end of the parcel in Quaternary alluvium and the southernmost end in Quaternary eolian deposits.

P-3 contains all four of the above units (King and Raymond, 1971). At State-scale (Martin and others, 2004), the parcel is shown almost entirely covered with Quaternary eolian deposits overlying undifferentiated White River Group, which contains Brule and Chadron Formations.

P-4 is mostly Pierre Shale overlain by Chadron Formation. No Interior Beds are mapped at the contact (King and Raymond, 1971). The State-scale map shows the lower elevations as Quaternary alluvium and the higher elevations in Pierre Shale and undifferentiated White River Group (Martin and others, 2004). There is a vague hint that a molybdenum and uranium prospect may exist in the vicinity (mrdata.usgs.gov), but the data are incomplete and unreliable.

P-5 is almost entirely in Chadron Formation (King and Raymond, 1971), part of the undifferentiated White River Group (Martin and others, 2004). A single uranium prospect, Hart Table prospect, may be located within a few miles to the east (mrdata.usgs.gov). 
No locatable minerals have been discovered or produced in the vicinity of these parcels. The mineral resource potential for locatable minerals on these five parcels is low.

\section{Federal Lands NF-4}

Folsom and Red Shirt NE 1:24,000; Wall 1:100,000, Hot Springs 1:250,000 quadrangles.

Parcel NF-4 is entirely within an area mapped as Pierre Shale (King and Raymond, 1971). The State geologic map (Martin and others, 2004) indicates the lower elevations are covered with Quaternary alluvium and the upper elevations with Quaternary terrace deposits.

There are no mines, prospects, or occurrences of any locatable minerals in the vicinity. Mineral resource potential for locatable minerals on this parcel is low.

\section{Federal Lands NF-1, NF-2, NF-3}

Fairburn NE 1:24,000; Mount Rushmore 1:100,000, Hot Springs 1:250,000 quadrangles.

As far as known, there is no detailed mapping of the area covering these three parcels. The entire area was mapped at 1:125,000 (Darton and Paige, 1925) as undifferentiated Brule and Chadron Formations. No larger scale maps of this area could be located. At State-scale (Martin and others, 2004, 1:500,000), parcels NF-1 and NF-3 are entirely within the White River Group, which includes the Brule and Chadron Formations. Pierre Shale is exposed in the southwestern part of Parcel NF-2 (Martin and others, 2004).

There are no known locatable mineral deposits near the parcels involved in the exchange (U.S. Geological Survey, 2004). (The feldspar deposit shown in the MAS dataset on the USGS mrdata.usgs.gov site on Red Shirt NE quad is erroneously located-it belongs in Cicero Peak quadrangle, four quadrangles to the west). The potential for locatable mineral resources is considered to be low. 


\section{REFERENCES:}

Darton, N.H., and Paige, Sidney, 1925, Central Black Hills, South Dakota: U.S. Geological Survey Geological Atlas of the United States, Folio 219, scale 1:125,000.

DeWitt, Ed, Redden, J.A., Buscher, D.P., and Wilson, A.B., 1989, Geologic map of the Black Hills area, South Dakota and Wyoming: U.S. Geological Survey Miscellaneous Investigations Series Map I-1910, scale 1:250,000.

King, R.U., and Raymond, W.H., 1971, Geologic map of the Scenic area, Pennington, Shannon, and Custer Counties, South Dakota: U.S. Geological Survey Miscellaneous Geologic Investigations Map I-662, scale 1:31,680.

Martin, J.E., Sawyer, J.F., Fahrenbach, M.D., Tomhave, D.W., and Schulz, L.D., 2004, Geologic map of South Dakota: South Dakota Geological Survey General Map 10, scale 1:500,000. [http://jurassic2.sdgs.usd.edu/pubs/pdf/SDGeomap_20040630.pdf]

U.S. Geological Survey, 2004, Mineral resources on-line spatial data, http://mrdata.usgs.gov/

\section{LIST OF ATTACHMENTS:}

A. Report request (provided by U.S. Forest Service).

B. Exhibit A, location of non-Federal land (provided by U.S. Forest Service).

C. Exhibit B, location of Federal land (provided by U.S. Forest Service).

D. Simplified geologic map (after Martin and others, 20̄0̈4). 


\section{Attachment A. Report request (provided by U.S. Forest Service)}

$\begin{array}{lll}\text { United States } & \text { Forest } & \begin{array}{l}\text { Rocky } \\ \text { Mountain } \\ \text { Department of }\end{array} \\ \text { Agriculture } & \text { Service } & \text { Region }\end{array}$

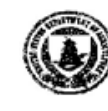
Agriculture
Anna Wilson

Geologist

U.S. Geological Survey MS 905

Central Mineral Resources

Box 25046-Denver Federal Center

Denver, CO 80225

Dear Ms. Wilson:

Dakota Partnership, a South Dakota partnership, whose address is P.O. Box 8303, Rapid City, South Dakota 57709, has offered certain non-Federal lands within the Buffalo Gap National Grassland, administered by the Nebraska National Forest, in exchange for Federal lands also within the Buffalo Gap National Grassland, administered by the Nebraska National Forest. These lands are described in Exhibits A and B enclosed herewith. The lands to be exchanged are depicted on the maps also provided.

In accordance with the working agreement under Public Law 86-509, please provide a report on the locatable mineral resources on the lands described in Exhibits A and B. Please specify in your report the mineral or minerals involved. Please send your report to the letterhead address.

If you have any questions, you may contact Nancy Hollenkamp at (303) 275-5382.

Sincerely,

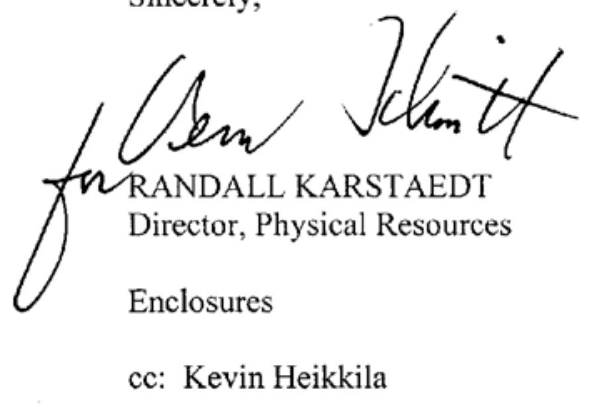


Attachment B. Exhibit A (provided by U.S. Forest Service)

\section{$\underline{\text { EXHIBIT A }}$}

Property that the Non-Federal Party will consider exchanging:

Black Hills Meridian, Pennington County, South Dakota

T. 3 S., R.11 E.,

Sec. 25, lots 6 and 8 ;

T. 3 S., R. 12 E.,

Sec. 19, lots 5 to 9 , inclusive, $\mathrm{NE}^{1 / 4} \mathrm{SW}^{1 / 4}, \mathrm{~N}^{1 / 2} \mathrm{SE}^{1 / 4}, \mathrm{SW}^{1 / 4} \mathrm{NE}^{1 / 4}$;

Sec. 20, SW11/4, NW1/4SE1/4, SW1/4SE1/4;

Sec. $22, N^{1} / 2 N^{1} 1 / 4$;

Sec. $28, \mathrm{SW}^{1} / 4 \mathrm{NW}^{1} / 4$;

Sec. 29, N1/2NW11/4, NW $1 / 4 \mathrm{SW}^{1} 1 / 4, \mathrm{SW}^{1} 1 / 4 \mathrm{NW}^{1 / 4}, \mathrm{~W}^{1} 1 / 2 \mathrm{NE}^{1 / 4}, \mathrm{SE}^{1 / 4} \mathrm{NE}^{1 / 4}$, $\mathrm{E}^{1 / 2} \mathrm{SE}^{1 / 4}, \mathrm{SW} 1 / 4 \mathrm{SE}^{1 / 4} / 4$

Sec. 30, lots 1 and 2, $\mathrm{SE}^{1 / 4} \mathrm{NE}^{1 / 4}, \mathrm{NE}^{1 / 4} \mathrm{SE}^{1 / 4}$;

Sec. 31 , lots 3 and $4, E^{1 / 2} \mathrm{SW}^{1 / 4}$;

Sec. $32, \mathrm{NE}^{1 / 4} \mathrm{NE}^{1 / 4}$;

Sec. 33, W1/2NW1/4, NW11/4SW1/4;

Sec. 35, N1/2NE1/4, SW11/4NE1/4, SE1/4NW1/4, E1/2SW1/4;

Sec. $36, \mathrm{SE}^{1 / 4}, \mathrm{~S}^{1 / 2} \mathrm{NE}^{1 / 4}$.

T. 4 S., R. 12 E., Sec. $2, \mathrm{NW}^{1 / 4} \mathrm{NE}^{1 / 4}, \mathrm{NE}^{1 / 4} \mathrm{NW}^{1 / 4}$.

The described areas aggregate 2196.50 acres. 
Attachment C. Exhibit B (provided by U.S. Forest Service)

\author{
EXHIBIT B
}

Property that the U.S.D.A. Forest Service will consider exchanging:

\title{
Black Hills Meridian, Custer County, South Dakota
}

T. 3 S., R. 11 E., Sec $26, W^{1 / 2} S^{1} 1 / 4, S^{1 / 4} S^{1} 1 / 4$;

Sec. $35, N^{1} 1 / 4 N^{1} / 4$.

T. 4 S., R. 9 E., Sec. 3, Lots 1-4, $\mathrm{S}^{1 / 2} \mathrm{NE}^{1 / 1} 4, \mathrm{~S}^{1 / 2} \mathrm{NW}^{1 / 4}, \mathrm{SE}^{1 / 4}, \mathrm{SW}^{1 / 4}$;

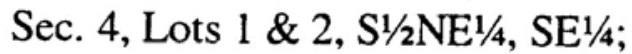

Sec. $5, \mathrm{~W}^{1} 1 / 2 \mathrm{SW}^{1 / 4}$;

Sec. $7, N^{1 / 4} N^{1 / 1 / 4}$;

Sec. $8, N W^{1 / 4} N^{1} 1 / 4$;

Sec. 9, NE1/4;

Sec. $10, N^{1} 1 / 4, E^{1 / 2}$;

Sec. $15, E^{1 / 2}$;

Sec. $20, E^{1 / 2}$;

Sec. $21, W^{1 / 2}, W^{1 / 2} S^{1 / 4}, W^{1 / 2 N} E^{1 / 4}$;

Sec. $28, \mathrm{~W}^{1 / 2}, \mathrm{~W}^{1 / 2} \mathrm{NE}^{1 / 4}, \mathrm{SE}^{1 / 4}$;

Sec. $29, E^{1 / 2} \mathrm{NE}^{1 / 4}, \mathrm{E}^{1 / 2} \mathrm{SE}^{1 / 4}, \mathrm{NW}^{1 / 4} \mathrm{NE}^{1 / 4}$.

The areas described aggregate 3801.38 acres. 
Attachment D. Simplified geologic map (after Martin and others, 2004) and approximate location of parcels considered for exchange (areas outlined in red are non-Federal parcels, areas in green are Federal parcels). Qal, Quaternary alluvium; Qt, Quaternary terrace deposits; Qe, Quaternary eolian; Tw, Tertiary (Oligocene and Eocene) White River Group (includes Brule and Chadron Formations); Kp, Upper Cretaceous Pierre Shale (includes Interior Beds).

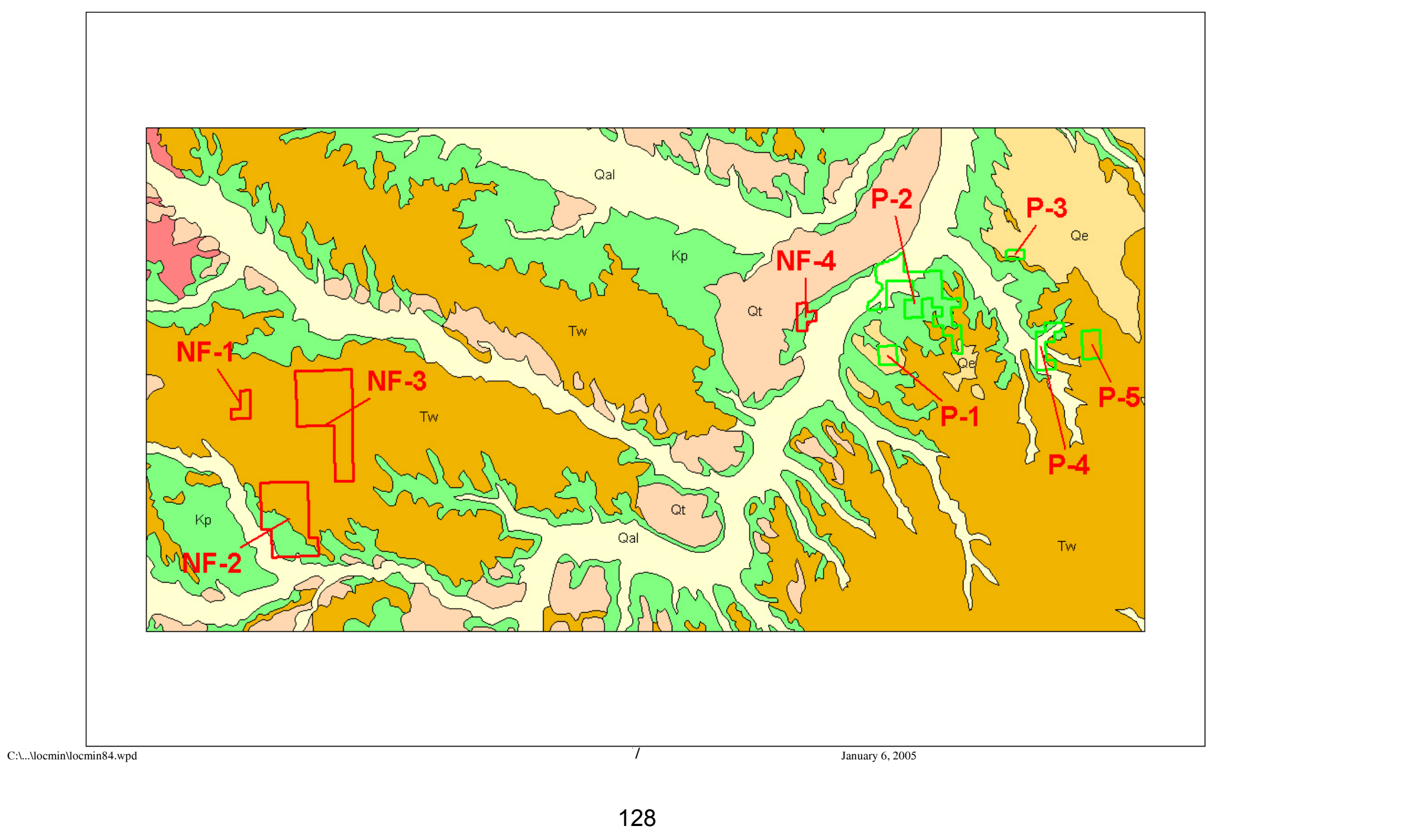




\title{
LOCATABLE MINERAL REPORT FOR THE MISSOURI BREAKS LAND EXCHANGE OFFER, FORT PIERRE NATIONAL GRASSLAND, NEBRASKA NATIONAL FOREST, STANLEY COUNTY, SOUTH DAKOTA
}

\author{
By \\ Anna B. Wilson \\ U.S. Geological Survey \\ Administrative Report
}

April 15, 2004

The following report is based on information contained in USGS mineral resource and commodity files, mineral information databases (MRDS and MAS), and on reports and maps available in the USGS library. These data are occasionally augmented with unpublished documents, personal communications, and professional experiences. No field studies or on-site visits were performed in preparing this report. Emphasis is primarily on locatable mineral resources. Leasable and salable resources are covered only if they appear in the above documents. Mineral resource assessments are subjective: the opinions expressed herein are entirely those of the author. 


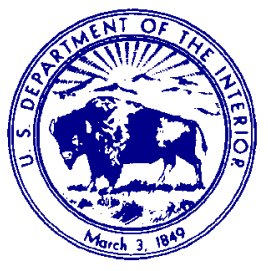

\section{U.S. Department of the Interior}

\section{U.S. Geological Survey}

Box 25046, MS 964

Denver Federal Center

Denver CO, 80225

(303) 236-5593

FAX (303) 236-3200

awilson@usgs.gov

April 15, 2004

Ms. Michele O'Connell

Acting Director, Physical Resources

U.S.D.A. Forest Service

PO Box 25127

Lakewood, CO 80225-0127

Dear Ms. O'Connell:

This report is in response to your January 23 request for information on locatable mineral resources in the Missouri Breaks land exchange proposal in which the Randy and Linda Stroup have offered certain non-Federal lands within the Fort Pierre National Grassland in exchange for Federal lands also within the Fort Pierre National Grassland.

In accordance with our long-term working agreement under Public Law 86-509, we are providing you with a report on the locatable mineral resources on the lands described in Exhibits $\mathrm{A}$ and $\mathrm{B}$, which were included with your request. These lands comprise approximately 512.59 acres in Stanley County, South Dakota.

Sincerely yours,

Anna B. Wilson, Geologist

Mineral Resources Program, Central Region

Copies: $\quad$ W.C. Day

E.A. du Bray

N. Hollenkamp

J.S. Dersch 


\section{Non-Federal and Federal Lands}

Rousseau 1:24,000, Canning 1:62,500, Pierre 1:100,000, Pierre 1:250,000 quadrangles.

All three parcels considered for this exchange are within about 2 square miles and have similar geologic settings. Each parcel contains the Virgin Creek Member of the Upper Cretaceous Pierre Shale (Crandell, 1954). The northern and southern parcels may include exposures of the underlying Verendrye Member, and the northernmost parcel also may include a small knob of the overlying Mobridge Member. From youngest to oldest, these units are described by Crandell (1954):

The Mobridge member consists of partly indurated calcareous shale. The proportion of calcium carbonate ranges from 15 to 27 percent. The member is gray where unoxidized and grayish orange where weathered. The shale tends to part along laminae, which range in thickness from one-sixtieth to onetenth of an inch. The color differences probably are related to variations in grain size, coarser grained laminae oxidizing more rapidly than the finer ones. Outcrops are restricted to seven small knobs in the southern part of the quadrangle from which the top of the member has been removed by erosion. The maximum thickness that remains is about 25 feet.

The Virgin Creek member consists of olive-gray to light olive-gray shale, claystone, mudstone, and intercalated beds of bentonite. The lower part of the member is predominantly shale that weathers into thin flakes and chips less than an inch in diameter. This lower part of the member contains 15 or more bentonite beds ranging in thickness from a fraction of an inch to 6 inches. The upper part of the member consists predominantly of claystone and mudstone that weather to gumbo. A zone of undetermined thickness at the top of the member is locally calcareous, although it has the same appearance as the underlying noncalcareous beds. Bentonite beds less than an inch thick are intercalated sporadically throughout the upper part of the member. The Virgin Creek member is very susceptible to slumping. The member is 120 feet thick in the southeast part of the Canning quadrangle [and may thicken to the west]. The top of the member is marked by a change in lithology from gray claystone to the grayishorange calcareous shale of the overlying Mobridge member.

The Verendrye member consists of 140 to 150 feet of light olive-gray to olive-gray mudstone and claystone and subordinate amount of shale. The member weathers to light olive-gray or brownish-gray gumbo. Because of the almost invariable gumbo cover, which is several inches to several feet thick, stratification is not readily visible on outcrops. The member contains concretions of iron-manganese carbonate that range from a few inches to several feet in diameter. These concretions are light olive-gray where fresh, dark purple where weathered. The Verendrye member forms smooth slopes wherever exposed and is subject to extensive slumping. The top of the member is marked by a transition from gumbo forming mudstone to shale and claystone of the Virgin Creek member that break down to small flakes and chips. This contact coincides with the base of a zone containing numerous bentonite beds in the lower part of the overlying Virgin Creek member. 
A prospect is located immediately to the northeast of the northernmost (Federal) parcel (USDA Forest Service, 1980). Glacial outwash and terrace deposits are mapped in that vicinity, so it is likely that the prospect is a sand and gravel deposit. This deposit should be examined to determine if it extends into the property considered in this exchange. Quaternary deposits having potential for sand and gravel are plentiful north of the Missouri River and east of the properties considered for this exchange.

Only the Pierre Shale is exposed in the study areas and "in general, Pierre shale is considered to be a poor material for use in constructing highway fills. In many places south and west of the Missouri River, however, no substitute is readily available (Crandell, 1954)." Crandell summarizes the resource potential negatively: "Nearly all the bedrock units and surficial deposits that occur in the quadrangle have been used at one time or another for fill material. In some cases such use has caused highway fill failure and other engineering difficulties."

Based on this assessment, mineral resource potential for locatable, leasable, and salable commodities on any of the parcels is low.

\section{REFERENCES:}

Crandell, D.R., 1954, Geologic map of the Canning Quadrangle, South Dakota: U.S. Geological Survey Geologic Quadrangle Map GQ-39, scale 1:62,500.

USDA Forest Service, 1980, Fort Pierre National Grassland, South Dakota-Grassland visitors map: U.S. Geological Survey, scale 1:126,720.

\section{LIST OF ATTACHMENTS:}
A. Report request (provided by USDA Forest Service).
B. Exhibit A. Legal description of non-Federal land considered in this exchange (provided by USDA Forest Service).
C. Exhibit B. Legal description of Federal land considered in this exchange (provided by USDA Forest Service).
D. Index map showing approximate locations of the land exchange parcels (provided by USDA Forest Service).
E. Simplified geologic map showing location of parcels. (After Crandell, 1954.) 


\section{Attachment A. Report request (provided by U.S. Forest Service)}

\begin{abstract}
United States
Department of Agriculture
\end{abstract}

$\begin{array}{ll}\text { Forest } & \text { Rocky } \\ \text { Service } & \text { Mountain } \\ & \text { Region }\end{array}$

P.O. Box 25127

Lakewood, CO 80225-0127

Delivery: $\mathbf{7 4 0}$ Simms Street

Golden, CO 80401

Voice: 303-275-5350

TDD: 303-275-5367
File Code: $5430-2-1$

Date:

JAN $2 \quad 32004$

\section{Anna Wilson}

Geologist

Central Mineral Resources

U.S. Geological Survey MS 905

Box 25046, Denver Federal Center

Denver, CO 80225

Dear Ms. Wilson:

Randy D. and Linda S. Stroup, of P.O. Box 14, Ft. Pierre, South Dakota 57532, have offered certain non-Federal lands within the Fort Pierre National Grassland, in exchange for Federal lands also within the Ft. Pierre National Grassland. These lands are generally described in Exhibits A and B enclosed herewith. The lands to be exchanged are depicted on the maps also provided.

In accordance with the working agreement under Public Law 86-509, please provide a report on the locatable mineral resources on the lands described in Exhibits A and B. Please specify in your report the mineral or minerals involved. Please send your report to the letterhead address.

If you have any questions, you may contact Nancy Hollenkamp at (303) 275-5382.

Sincerely,

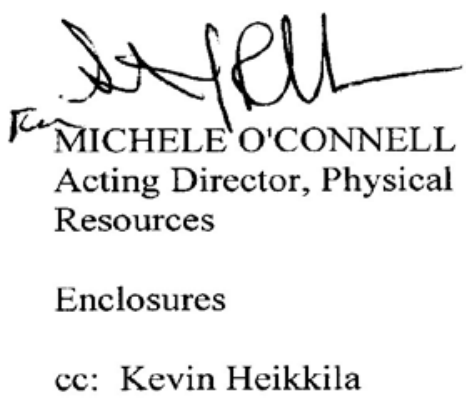




\section{Attachment B. Exhibit A (provided by U.S. Forest Service)}

\section{EXHIBIT A}

Property that the Non-Federal Party will consider exchanging:

Fifth Principal Meridian, Stanley County, South Dakota

T. 109 N., R. 77 W.,

Sec. 5, S1/2SE1/4;

Sec. 8, N1/2NE1/4 and E1/2SE1/4.

80.00 acres

160.00 acres

The area described contains 240.00 acres.

Subject to:

Reservations: None

Outstanding Rights:

1. through 6. - General exceptions. (Administratively acceptable)

7. Buried Exchange Facility Easement, to Northwestern Bell Telephone Company, an Iowa Corporation, its associated and allied companies, given for the purposes to construct, operate, maintain, replace, and remove a communications system, consisting of buried cable or wires, surface terminals, surface markers (at fence lines, if any) and associated equipment together with the right of access thereto for the purpose of exercising the rights herein granted, over and across the following: (Administratively acceptable)

a. Recorded December 14, 1976 @ 9:25 A.M. in Book 207 of Misc., Pages 627-628, conveying: T.109 N., R. 77 W., of $5^{\text {th }}$ Principal Meridian

Sec. 8: E1/2NE1/4Ne1/4; Sec. 9: N1/2N1/2NW1/4.

b. Recorded July 8, 1980 @ 3:42 P.M. in Book 218 of Misc., Pages 656-657, conveying: T. 109 N., R. 77 W., of $5^{\text {th }}$ Principal Meridian

Sec. 5: NE1/4SE1/4SE1/4.

8. Mortgage, dated December 22, 1993, executed by Randy D. Stroup and Linda S. Stroup, given to Hall and Hall Mortgage Corporation to secure the principal sum of $\$ 280,000.00$, interest thereon and any other obligations secured thereby. Due January 1, 2009. Recorded December 22, 1993 @ 4:15 P.M. in Book 249 of Mort., Pages 450-472. Assigned to Prudential Insurance Company of America Assignment of Mortgage dated January 24, 2994. Recorded January 27, 1994 @ 9:30 A.M. in Book 249 of Mort., Pages 556-559. (Unacceptable; remove - shall be released of record at or prior to closing of this transaction.)

Other:

1. The non-Federal party shall work with West Central Electric Coop, Inc., to obtain and record an easement for the existing $14.4 \mathrm{KV}$ overhead transmission lines that cross the east side of the parcels. This shall be completed at or prior to closing of this transaction.

2. If the mineral report shows that the locatable, leasable, and salable potential is low and the appraisals show there is no mineral value, the non-Federal party will convey minerals.

3. The non-Federal party agrees to provide all fencing materials and labor to reconstruct a three-wire fence along the east boundary of the Missouri Breaks Allotment if the land exchange is completed as proposed. This will deter livestock from entering onto the Presho County Road.

4. Livestock Grazing Permits: Randy Stroup hereby agrees to terminate any and all existing private grazing arrangement on the non-Federal lands identified for exchange to the United States upon completion of the exchange. This non-Federal land is already included in the Federal grazing permit for the Missouri Breaks Allotment issued to the Pioneer Grazing Association. (Note: Waiver of Grazing Authorization was signed August 12, 2003). 


\section{Attachment C. Exhibit B (provided by U.S. Forest Service). \\ EXHIBIT B}

Property that the U.S.D.A. Forest Service will consider exchanging:

Fifth Principal Meridian, Stanley County, South Dakota

T. 109 N., R. 77 W..

Sec. 4, Lot $3 \& 4$

Sec. 5, That part of section 5 lying northerly and easterly of the centerline

79.09 acres of Highway 1806 contains 193.5 acres of which 11.8 acres lies under the Hwy Right-of-Way.

193.50 acres

The area described contains 272.59 acres.

Subject to:

Reservations: None

Outstanding Rights: None

Other:

1. If the mineral report shows that the locatable, leasable, and salable potential is low and the appraisals show there is no mineral value, the Forest Service will convey minerals.

2. The Special Use Permit for the 14.4 KV overhead transmission line issued to West Central Electric Inc., will be amended and the non-Federal party will work with the permittee to issue a replacement easement that shall be executed at closing of this transaction. 
Attachment D. Index map showing location of Missouri Breaks Land Exchange and vicinity (provided by USDA Forest Service).

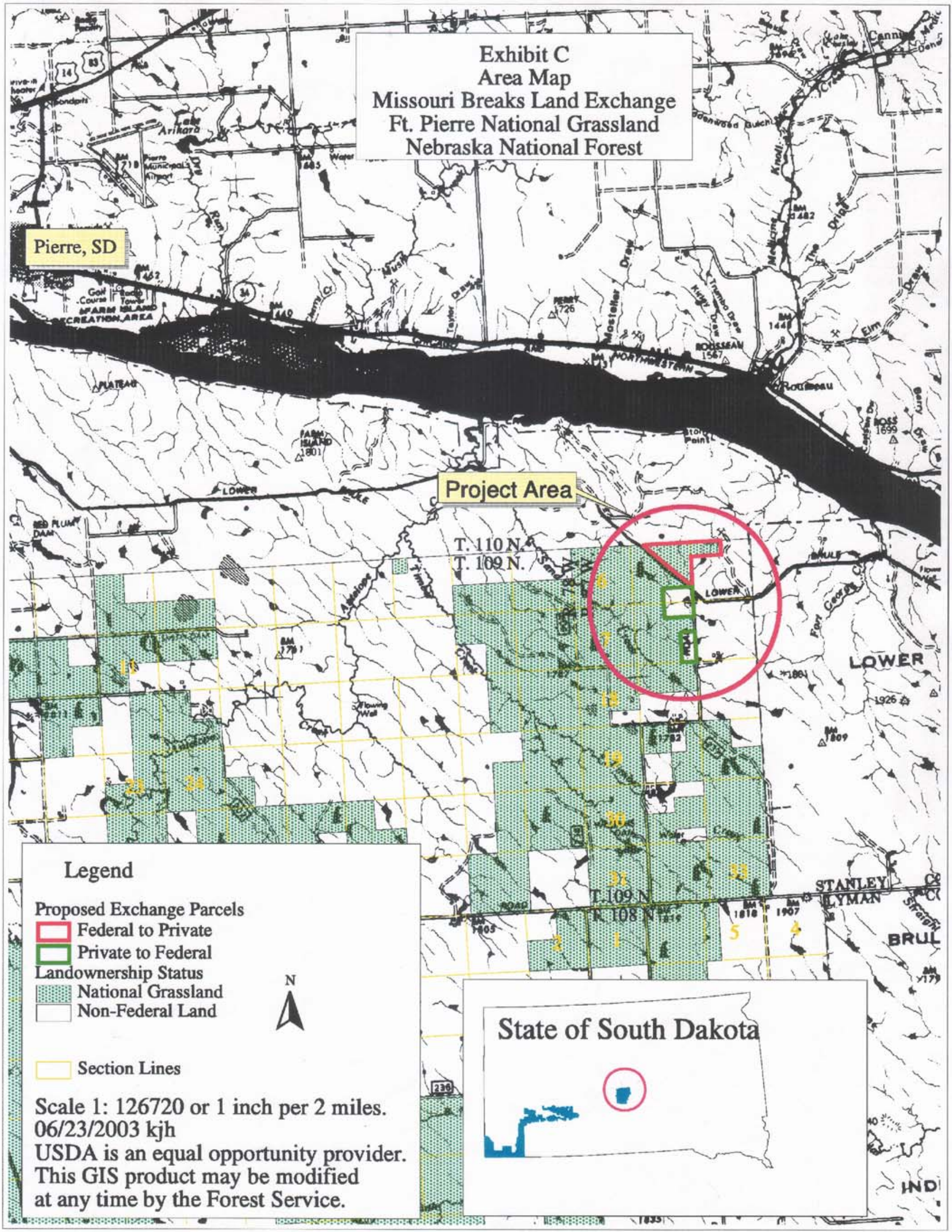




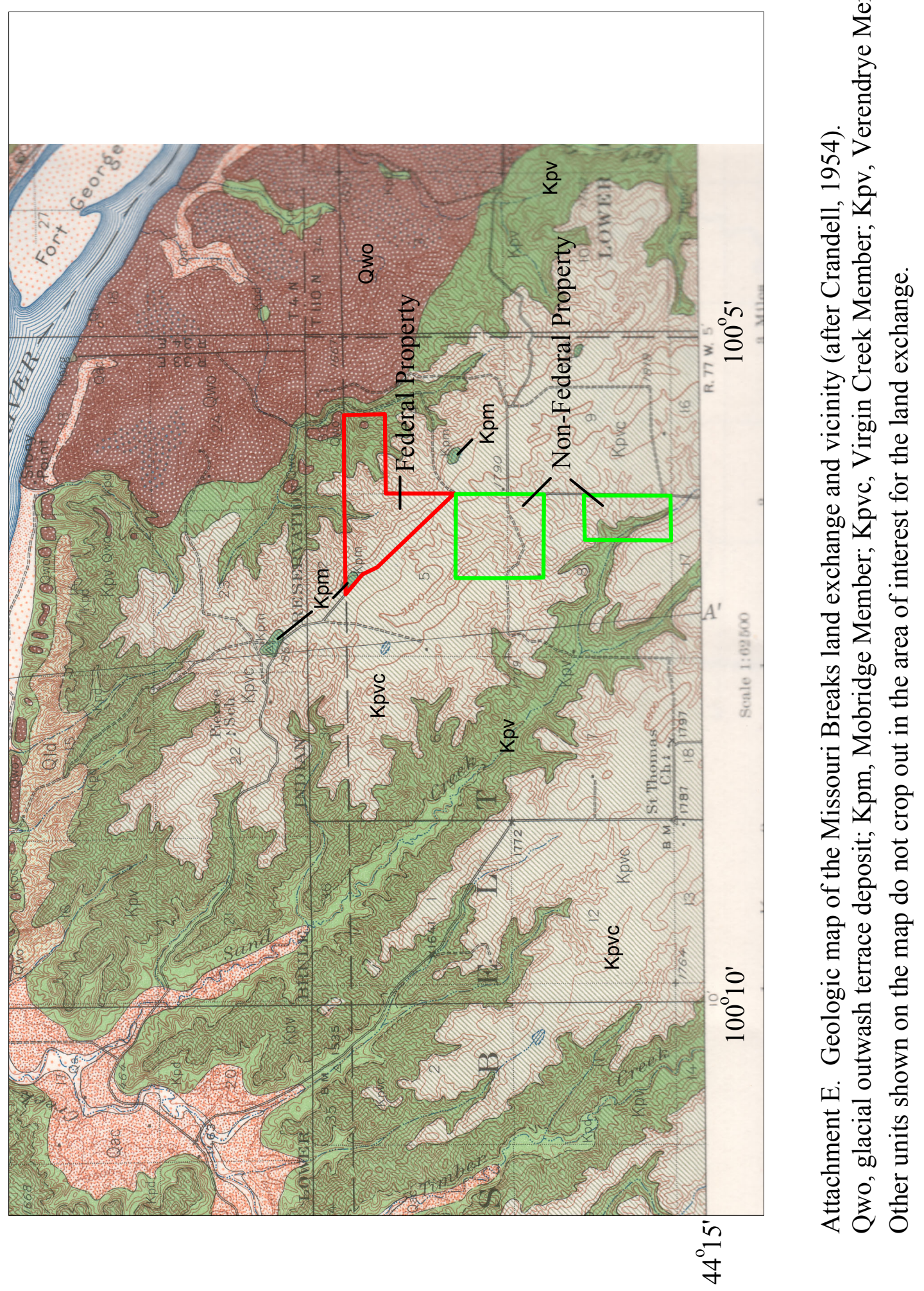




\section{WYOMING}




\title{
LOCATABLE MINERAL REPORT FOR THE CITY OF BUFFALO EXCHANGE OFFER, BLACK HILLS AND BIGHORN NATIONAL FORESTS, CROOK AND JOHNSON COUNTIES, WYOMING
}

\author{
By \\ Anna B. Wilson \\ U.S. Geological Survey \\ Administrative Report
}

December 12, 2003

The following report is based on information contained in USGS mineral resource and commodity files, mineral information databases (MRDS and MAS), and on reports and maps available in the USGS library. These data are occasionally augmented with unpublished documents, personal communications, and professional experiences. No field studies or on-site visits were performed in preparing this report. Emphasis is primarily on locatable mineral resources. Leasable and salable resources are covered only if they appear in the above documents. Mineral resource assessments are subjective: the opinions expressed herein are entirely those of the author. 


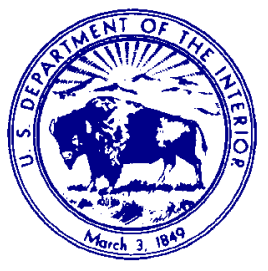

U.S. Department of the Interior

U.S. Geological Survey

Box 25046, MS 964

Denver Federal Center

Denver CO, 80225

(303) 236-5593

FAX (303) 236-3200

awilson@usgs.gov

December 12, 2003

Mr. Mike Doran

Acting Director, Physical Resources

U.S.D.A. Forest Service

PO Box 25127

Lakewood, CO 80225-0127

Dear Mr. Doran:

This report is in response to your November 17 request for information on locatable mineral resources in the Tie Hack Reservoir land exchange proposal in which the City of Buffalo, Johnson County, Wyoming, has offered certain non-Federal lands within the Black Hills National Forest in exchange for Federal lands within the Bighorn National Forest.

In accordance with our long-term working agreement under Public Law 86-509, we are providing you with a report on the locatable mineral resources on the lands described in Exhibits $\mathrm{A}$ and $\mathrm{B}$, which were included with your request. These lands comprise approximately 418.63 acres in Crook and Johnson Counties, Wyoming.

Sincerely yours,

Anna B. Wilson, Geologist

Mineral Resources Program, Central Region

Copies: $\quad$ W.C. Day

E.A. du Bray

N. Hollenkamp

J.S. Dersch 
For the legal location description of lands considered for exchange, refer to Exhibits A and B in Attachments A and B. The report request is Attachment C. Attachments D and E are simplified geologic maps showing the location of the Federal and Non-Federal parcels. Attachment $\mathrm{F}$ is an index map showing general location of the land exchange parcels.

\section{Non-Federal Lands}

\section{Dugout Gulch Property}

Tinton 1:24,000, Tinton 1:62,500, Sundance 1:100,000, Gillette 1:250,000 quadrangles.

The Dugout Gulch property is approximately 4 mi south of Beulah, Wyoming, in the NW corner of the Tinton 1:24,000 quadrangle. The area includes the ridge separating Dugout Gulch on the west from Hospital Gulch on the east. It is mapped (DeWitt and others, 1989, as compiled from Darton, 1905) as lower Permian and Pennsylvanian Minnelusa Formation (light-brown to red and gray sandstone, solution breccia, limestone, and shale) overlain by Lower Permian Opeche Shale (red silty shale) and topped by Lower Permian Minnekahta Limestone (gray to purplishgray, slabby limestone).

No mines, prospects, occurrences, or mining districts are in the immediate vicinity (Wilson and DeWitt, 1995). At a resource assessment at 1:250,000-scale, the area falls within a large tract assigned high potential for large bedded deposits of high-calcium limestone and within a tract assigned low potential for small to medium stratabound deposits of oil and gas (DeWitt and others, 1986).

\section{Federal Lands}

\section{Tie Hack Reservoir}

Hunter 1:24,000, Buffalo 1:100,000, Sheridan 1:250,000 quadrangles.

The Tie Hack Reservoir area is about 11 miles west-southwest of Buffalo and 3 to 4 miles east of the Cloud Peak Primitive area. The reservoir was constructed between 1996 and 1998. The area surrounding the reservoir is entirely within Archean granite gneiss composed chiefly of quartz, plagioclase, biotite, and microcline and cut by several northeast-strikinging dikes of diabase, diorite, or metabasalt (Hinrichs and others, 1990). The Wyoming State map (Love and Christiansen, 1985, 1:500,000 scale) shows the same outcrop pattern for the early Archean oldest gneiss complex but describes the unit as layered granitic gneiss that is locally migmatitic. There may also be local masses of quartzite, metagraywacke, iron-formation, and other metasedimentary rocks, and amphibolite and felsic gneiss thought to be volcanic in origin. Metamorphism occurred in the Bighorn Mountains more than 3 billion years ago (Love and Christiansen, 1985).

No mines or prospects are located in the same Precambrian metamorphic rock unit anywhere in the vicinity of the reservoir (Wilson and others, 2001). Mineral resource potential for locatable commodities in the vicinity of the reservoir is low. 


\section{REFERENCES:}

DeWitt, Ed, Redden, J.A., Buscher, David, and Wilson, A.B., 1989, Geologic map of the Black Hills area, South Dakota and Wyoming: U.S. Geological Survey Miscellaneous Investigations Series Map I-1910, scale 1:250,000.

DeWitt, Ed, Redden, J.A., Wilson, A.B., and Buscher, David, 1986, Mineral resource potential and geology of the Black Hills National Forest, South Dakota and Wyoming, with a section on Salable commodities, by John S. Dersch: U.S. Geological Survey Bulletin 1580, 135 p., 4 plates.

Hinrichs, E.N., Kent, B.H., and Pierce, F.W., 1990, Bedrock geologic map and coal sections in the Buffalo 30' x 60' quadrangle, Johnson and Campbell Counties, Wyoming: U.S. Geological Survey Miscellaneous Investigations Series Map I-1923-A, scale 1:100,000.

Love, J.D., and Christiansen, A.C., 1985, Geologic map of Wyoming: U.S. Geologic Survey State Geologic Map, 3 plates, scale 1:500,000.

Wilson, A.B., and DeWitt, Ed, 1995, Maps showing metallic mineral districts and mines in the Black Hills, South Dakota and Wyoming: U.S. Geological Survey Miscellaneous Investigations Series Map I-2445, scale 1:100,000.

Wilson, A.B., Klein, T.L., and Heran, W.D., 2001, Databases and simplified geology for mineralized areas, claims, mines, and prospects in Wyoming: U.S. Geological Survey Open-File Report 01-497 [http://pubs.usgs.gov/of/2001/ofr-01-0497/].

\section{LIST OF ATTACHMENTS:}

A. Exhibit A. Legal description of non-Federal land considered in this exchange (provided by U.S. Forest Service).

B. Exhibit B. Legal description of Federal land considered in this exchange (provided by U.S.D.A. Forest Service).

C. Report request (provided by U.S.D.A. Forest Service).

D. Simplified geologic map showing location of non-Federal parcel. (After DeWitt and others, 1989.)

E. Simplified geologic map showing location of Federal parcel. (After Hinrichs and others, 1990.)

F. Index map showing approximate locations of the land exchange parcels. 


\section{Attachment A. Exhibit A (provided by U.S. Forest Service)}

\section{$\underline{\text { EXHIBIT A }}$}

Property that the City of Buffalo, Wyoming, will consider exchanging:

T. 52., R. 60W., 6th Principal Meridian, Crook County, Wyoming

Sec 19, Lots 3 (41.14), 4 (40.25), E2SW4, and SE4

All totaling 320.39 acres, more or less

Land reservations of the City of Buffalo, Wyoming, and exceptions to title:

Reservations: None

Outstanding Rights:

1) Easement Deed for Roads, $40^{\prime}$ in width, across T. 52N., R. 60W., $6^{\text {th }}$ P.M., Section 19: Lot 3 $\& 4$ in SE1/4SW1/4, for easements for the Dugout Road No. 864.1 and Dugout Road No. 864.1A and incidental purposes granted to United States of America by instrument recorded February 24, 1983, in Book 201 of Photos, Page 537.

2) Taxes and assessments not shown by the records of the County Treasurer.

3) Lack of a right of access to and from the land.

Other:

1) All minerals are outstanding to the State of Wyoming. 


\title{
Attachment B. Exhibit B (provided by U.S. Forest Service)
}

\author{
$\underline{\text { EXHIBIT B }}$ \\ Property that the U.S.D.A. Forest Service will consider exchanging: \\ T. 50 N., R. 84 W., $6^{\text {th }}$ Principal Meridian, Johnson County, Wyoming \\ Tract 37 \\ Totaling 98.24 acres, more or less \\ Land reservations of the U.S.D.A. Forest Service, exceptions to title and uses to be recognized: \\ Reservations:
}

1. Reserving to the United States a right-of-way thereon for ditches or canals constructed by the authority of the United States Act of August 30, 1890 (26 Stat. 391; 43 U.S.C. 845).

Outstanding Rights: None

Other:

1. The landowner shall agree to donate a permanent conservation easement to an approved third party for public use and access to the reservoir, as well as for minimum pool conditions and bypass flows as established through the special use permit issued to The City of Buffalo on 2/22/1996.

2. Special Use Permit for a Dam/Reservoir issued to the City of Buffalo on $2 / 22 / 1996$ to be terminated at or prior to closing.

3. A non-exclusive easement will be granted by the BLM to the non-federal party across National Forest System lands (FSR $21-4.12$ acres) to access the conveyed lands. 


\section{Attachment C. Report request (provided by U.S. Forest Service).}

\begin{tabular}{llll} 
United States & Forest & Rocky & P.O. Box 25127 \\
Department of & Service & Mountain & Lakewood, CO 80225-0127 \\
Agriculture & & Region & Delivery: 740 Simms Street \\
& & Golden, CO 80401 \\
& & Voice: 303-275-5350 \\
& & TDD: $303-275-5367$ \\
\hline
\end{tabular}

File Code: $5430-2-1$

Date: $\operatorname{lON} 172003$

Anna Wilson

Geologist

Central Mineral Resources

U.S. Geological Survey MS 905

Box 25046 - Denver Federal Center

Denver, CO 80225

Dear Ms. Wilson:

The City of Buffalo, Johnson County, Wyoming, whose address is 46 No. Main, Buffalo, Wyoming 82834, has offered certain non-Federal lands within the Black Hills National Forest, in exchange for Federal lands within the Bighorn National Forest. These lands are generally described in Exhibits A and B enclosed herewith. The lands to be exchanged are depicted on the maps also provided.

In accordance with the working agreement under Public Law 86-509, please provide a report on the locatable mineral resources on the lands described in Exhibits A and B. Please specify in your report the mineral or minerals involved. Please send your report to the letterhead address.

If you have any questions, you may contact Nancy Hollenkamp at (303) 275-5382.

Sincerely,

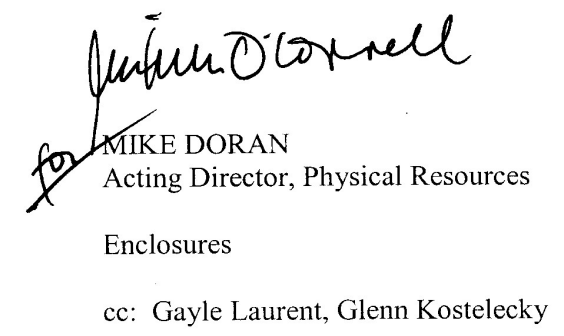

(Ui⿱s

Caring for the Land and Serving People

Printed on Recycled Paper 


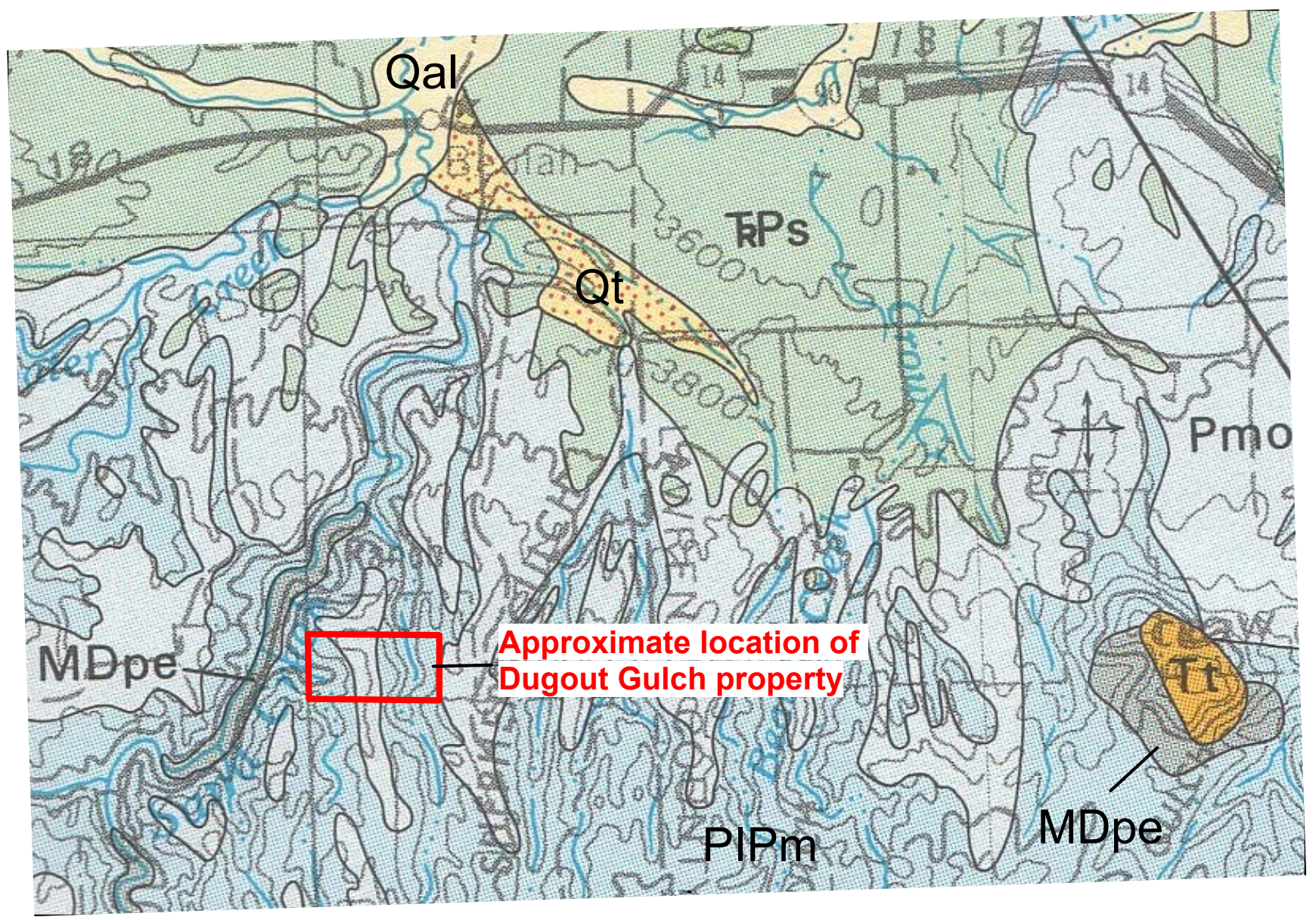

0

2.5

5

miles

1 


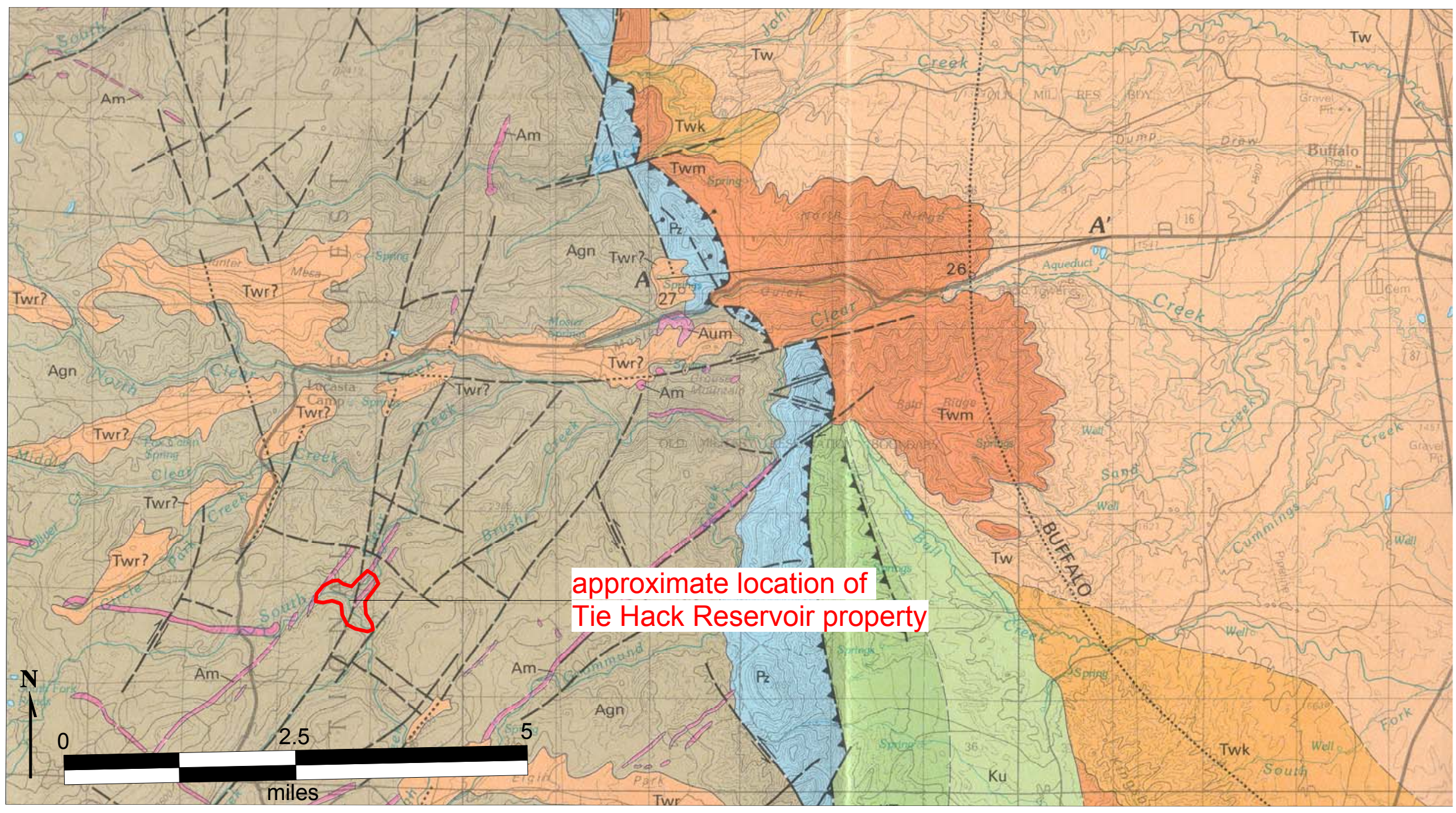




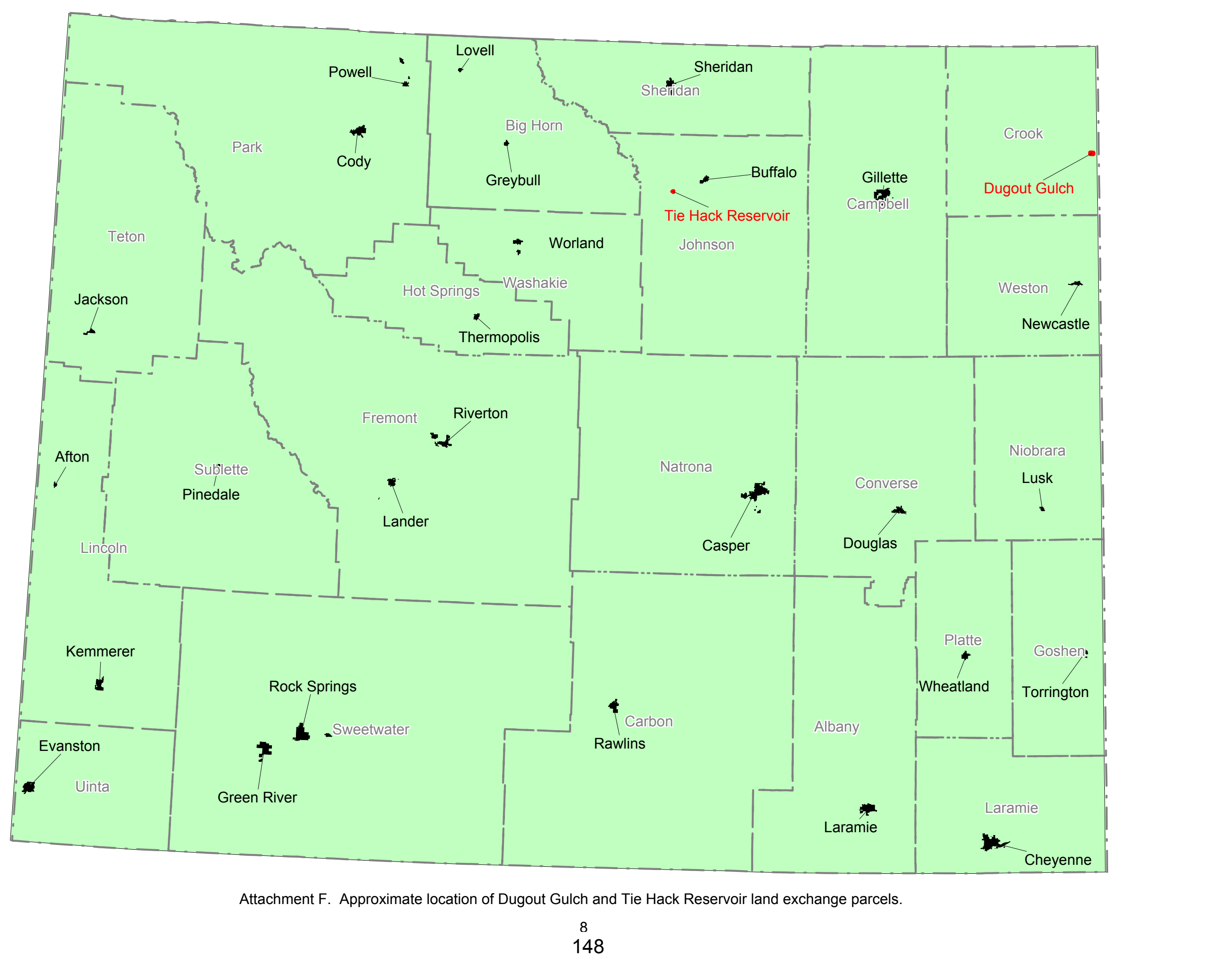




\title{
LOCATABLE MINERAL REPORT FOR THE COW CREEK (Thomson) LAND EXCHANGE OFFER, THUNDER BASIN NATIONAL GRASSLAND, MEDICINE BOW NATIONAL FOREST, CONVERSE COUNTY, WYOMING
}

\author{
By \\ Anna B. Wilson \\ U.S. Geological Survey \\ Administrative Report
}

January 19, 2005

The following report is based on information contained in USGS mineral resource and commodity files, mineral information databases (MRDS and MAS), and on reports and maps available in the USGS library. These data are occasionally augmented with unpublished documents, personal communications, and professional experiences. No field studies or on-site visits were performed in preparing this report. Emphasis is primarily on locatable mineral resources. Leasable and salable resources are covered only if they appear in the above documents. Mineral resource assessments are subjective: the opinions expressed herein are entirely those of the author. 


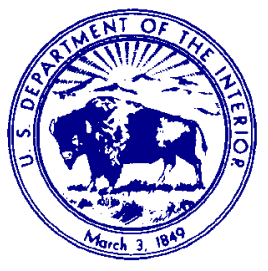

U.S. Department of the Interior

U.S. Geological Survey

Box 25046, MS 964

Denver Federal Center

Denver CO, 80225

(303) 236-5593

FAX (303) 236-3200

awilson@usgs.gov

January 19, 2005

Randall Karstaedt

Director, Physical Resources

U.S.D.A. Forest Service

P.O. Box 25127

Lakewood, CO 80225-0127

Dear Mr. Karstaedt:

This report is in response to your January 11 request for information on locatable mineral resources in the Cow Creek land exchange proposal in which David R. Thomson has offered certain non-Federal lands within the Thunder Basin National Grassland in exchange for Federal lands also within the Thunder Basin National Grassland.

In accordance with our long-term working agreement under Public Law 86-509, we are providing you with a report on the locatable mineral resources on the lands described in Exhibits $\mathrm{A}$ and $\mathrm{B}$, which were included with your request. These lands comprise approximately 1,320.52 acres in Converse County, Wyoming.

Sincerely yours,

Anna B. Wilson, Geologist

Mineral Resources Program, Central Region

Copies: $\quad$ C.J. Nutt

N. Hollenkamp

J.S. Dersch 
The report request is Attachment A. For the legal location description of lands considered for exchange, exclusive of reservations or outstanding rights, refer to Exhibits $\mathrm{A}$ and $\mathrm{B}$ in Attachment B. Attachment $\mathrm{C}$ is a simplified geologic maps showing the location of the Federal and Non-Federal parcels.

\section{Federal and Non-Federal Lands}

Cow Creek Land Exchange

Pinacle Rocks, Split Hill 1:24,000; Lance Creek 1:100,000; Newcastle 1:250,000 quadrangles.

All of the properties considered for exchange are on the southeastern flank of the Powder River Basin. The geology is mapped at State-scale as the lower part of the Lebo Member of the Tertiary Fort Union Formation. The Lebo Member is primarily dark-gray clay shale and concretionary sandstone (Love and Christiansen, 1985). Attachment $\mathrm{C}$ is a simplified geologic map after Green and Drouillard (1994) and Wilson and others (2001) showing the location of the parcels in the Fort Union Formation.

No mines, prospects, occurrences, or mining districts for locatable commodities are in the immediate vicinity (Wilson and others, 2001). Mineral resource potential for locatable commodities on all of the parcels considered in this exchange is equally low.

\section{REFERENCES:}

Green, G.N., and Drouillard, P.H., 1994, The digital geologic map of Wyoming in ARC/INFO format: U.S. Geological Survey Open-File Report 94-0425. [http://pubs.usgs.gov/of/1994/ofr-94-0425]

Love, J.D., and Christiansen, A.C., 1985, Geologic map of Wyoming: U.S. Geologic Survey State Geologic Map, 3 plates, scale 1:500,000.

Wilson, A.B., Klein, T.L., and Heran, W.D., 2001, Databases and simplified geology for mineralized areas, claims, mines, and prospects in Wyoming: U.S. Geological Survey Open-File Report 01-497. [http://pubs.usgs.gov/of/2001/ofr-01-0497/]

\section{LIST OF ATTACHMENTS:}

A. Report request (provided by U.S.D.A. Forest Service).

B. Exhibits A and B. Legal description of lands considered in this exchange (provided by U.S. Forest Service).

C. Simplified geologic map showing location of parcels. (After Wilson and others, 2001.) 


\section{Attachment A. Report request (provided by U.S. Forest Service).}

$\begin{array}{lll}\text { United States } & \text { Forest } & \text { Rocky } \\ \text { Department of } & \text { Service } & \begin{array}{l}\text { Mountain } \\ \text { Region }\end{array} \\ \text { Agriculture } & & \end{array}$

P.O. Box 25127

Lakewood, CO 80225-0127

Delivery: 740 Simms Street

Golden, CO 80401

Voice: 303-275-5350

TDD: $303-275-5367$

File Code: $5430-2-1$

Date:

Anna Wilson

JAN 112005

Geologist

Central Mineral Resources

U.S. Geological Survey MS 905

Box 25046-Denver Federal Center

Denver, CO 80225

Dear Ms. Wilson:

David R. Thomson, of 3800 Walker Creek Road, Douglas, Wyoming 83536, has offered certain non-Federal lands within the Thunder Basin National Grassland, administered by the Medicine Bow National Forest, in exchange for Federal lands also within the Thunder Basin National Grassland, administered by the Medicine Bow National Forest. These lands are generally described in Exhibits A and B enclosed herewith. The lands to be exchanged are depicted on the maps also provided.

In accordance with the working agreement under Public Law 86-509, please provide a report on the locatable mineral resources on the lands described in Exhibits A and B. Please specify in your report the mineral or minerals involved. Please send your report to the letterhead address.

If you have any questions, you may contact Nancy Hollenkamp at (303) 275-5382.

Sincerely,

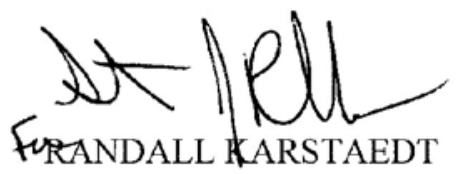

Director, Physical Resources

Enclosures

cc: Theodore W Cook, Tom Florich 


\section{Attachment B. Exhibits A and B (provided by U.S. Forest Service) EXHIBIT A}

Property that the Non-Federal Party will consider exchanging:

\section{Sixth Principal Meridian, Converse County, Wyoming}

\section{T. 38 N., R. 67 W.,}

Sec. $20, W^{1 / 2}$;

Sec. $29, \mathrm{~W} \frac{1}{2} \mathrm{NW}^{1} \frac{1}{4}$;

Sec. $31, \mathrm{~N}^{1 / 2} \mathrm{SE}^{1 / 4} / 4$

Sec. $32, \mathrm{NW}^{1 / 4} \mathrm{SW}^{1 / 4}$.
320.00 acres

80.00 acres

80.00 acres

40.00 acres

Total 520.00 Acres

Optional Acres for inclusion if needed to equalize values $* *$

T. 38 N., R. 67 W.,

Sec. $31, \mathrm{~S}^{1} / 2 \mathrm{SE}^{1} / 4$.
** 80.00 acres

\section{EXHIBIT B}

Property that the U.S.D.A. Forest Service will consider exchanging:

\section{Sixth Principal Meridian, Converse County, Wyoming}

T. 38 N., R. 67 W.,

Sec. $28, \mathrm{E}^{1 / 2} \mathrm{NE}^{1 / 4}, \mathrm{NE}^{1 / 4} \mathrm{NW}^{1 / 4}, \mathrm{NE}^{1 / 4} \mathrm{SE}^{1 / 4}$

160.00 acres

Sec. $29, E^{1 / 2} S^{1} 1 / 4$;

80.00 acres

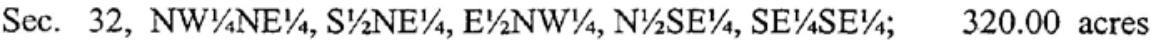

Sec. $33, W^{1 / 2} \mathrm{SW}^{1 / 4}$.

80.00 acres

Total 640.00 Acres

T. 37 N., R. 67 W.

Optional Acres for inclusion if needed to equalize values**

Sec. 4, Lot $4, \mathrm{SW}^{1 / 4} \mathrm{NW}^{1 / 4}$.

** 80.52 acres

(Total Optional Acres 80.52) 
Attachment C. Simplified geologic map showing approximate location of lands considered for exchange. (After Wilson and others, 2001.)

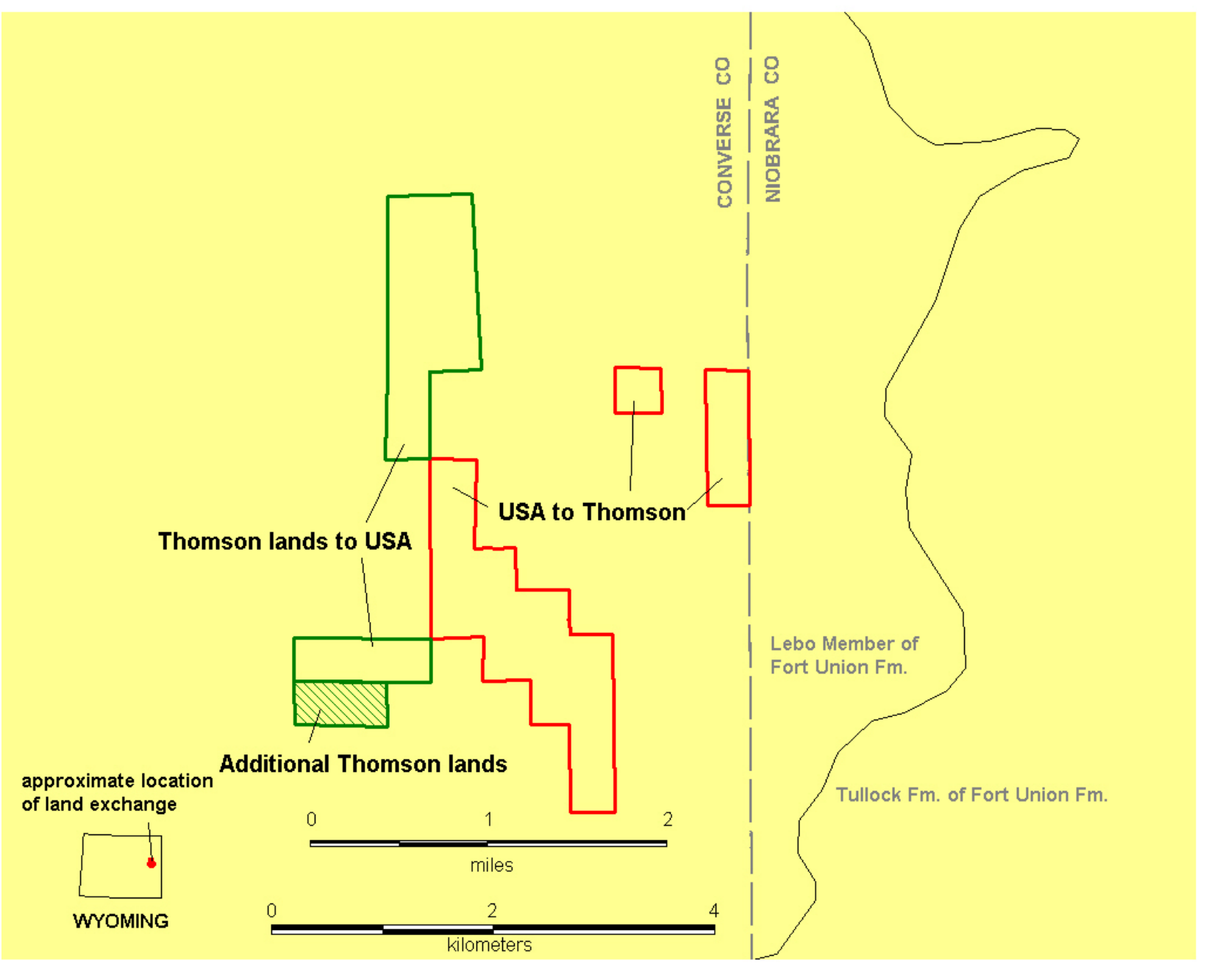




\section{U.S. Department of the Interior \\ Gale A. Norton, Secretary}

\section{U.S. Geological Survey \\ P. Patrick Leahy, Acting Director}

U.S. Geological Survey, Reston, Virginia 2006

For product and ordering information:

World Wide Web: http://www.usgs.gov/pubprod

Telephone: 1-888-ASK-USGS

For more information on the USGS - the Federal source for science about the Earth, its natural and living resources, natural hazards, and the environment:

World Wide Web: http://www.usgs.gov

Telephone: 1-888-ASK-USGS

Any use of trade, product, or firm names is for descriptive purposes only and does not imply endorsement by the U.S. Government.

Although this report is in the public domain, permission must be secured from the individual copyright owners to reproduce any copyrighted material contained within this report.

This report has not been reviewed for stratigraphic nomenclature. 